NBS MONOGRAPH 27-Supplement 2

\title{
$A 11100988664$
}

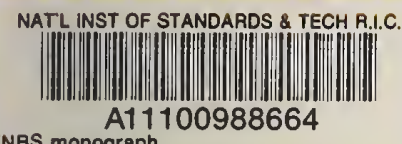

NBS monograph
QC100.U556 V27;SUPP2;1967 C.1 NBS-PUB-C

\section{(1)}

Bibliography of

Temperature Measurement

July 1960 to December 1965

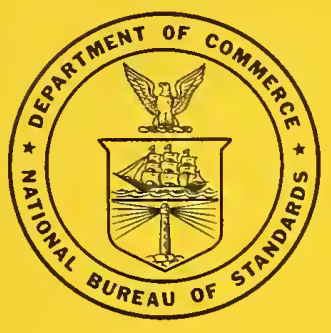

U.S. DEPARTMENT OF COMMERCE

NATIONAL BUREAU OF STANDARDS 


\section{THE NATIONAL BUREAU OF STANDARDS}

The National Bureau of Standards ${ }^{1}$ provides measurement and technical information services essential to the efficiency and effectiveness of the work of the Nation's scientists and engineers. The Bureau serves also as a focal point in the Federal Government for assuring maximum application of the physical and engineering sciences to the advancement of technology in industry and commerce. To accomplish this mission, the Bureau is organized into three institutes covering broad program areas of research and services:

THE INSTITUTE FOR BASIC STANDARDS ... provides the central basis within the United States for a complete and consistent system of physical measurements, coordinates that system with the measurement systems of other nations, and furnishes essential services leading to accurate and uniform physical measurements throughout the Nation's scientific community, industry, and commerce. This Institute comprises a series of divisions, each serving a classical subject matter area:

-Applied Mathematics-Electricity-Metrology-Mechanics-Heat-Atomic Physics-Physical Chemistry-Radiation Physics-Laboratory Astrophysics ${ }^{2}$ - Radio Standards Laboratory, ${ }^{2}$ which includes Radio Standards Physics and Radio Standards Engineering-Office of Standard Reference Data.

THE INSTITUTE FOR MATERIALS RESEARCH . . . conducts materials research and provides associated materials services including mainly reference materials and data on the properties of materials. Beyond its direct interest to the Nation's scientists and engineers, this Institute yields services which are essential to the advancement of technology in industry and commerce. This Institute is organized primarily by technical fields:

-Analytical Chemistry-Metallurgy-Reactor Radiations-Polymers-Inorganic Materials-Cryogenics ${ }^{2}$-Materials Evaluation Laboratory-Office of Standard Reference Materials.

THE INSTITUTE FOR APPLIED TECHNOLOGY . . . provides technical services to promote the use of available technology and to facilitate technological innovation in industry and government. The principal elements of this Institute are:

-Building Research-Electronic Instrumentation-Textile and Apparel Technology CenterTechnical Analysis-Center for Computer Sciences and Technology-Office of Weights and Measures-Office of Engineering Standards Services-Office of Invention and Innovation-Clearing. house for Federal Scientific and Technical Information. ${ }^{3}$

${ }^{1}$ Headquarters and Laboratories at Gaithersburg, Maryland, unless otherwise noted; mailing address Washington, D. C., 20234.

2 Located at Boulder, Colorado, 80302.

${ }^{3}$ Located at 5285 Port Royal Road, Springfield, Virginia, 22151. 
UNITED STATES DEPARTMENT OF COMMERCE - Alexander B. Trowbridge, Acting Secretary NATIONAL BUREAU OF STANDARDS • A. V. Astin, Director

\title{
Bibliography of Temperature Measurement
}

\author{
July 1960 to December 1965
}

\author{
Lief O. Olsen and Carl Halpern \\ Institute for Applied Technology \\ National Bureau of Standards \\ Washington, D.C. 20234
}

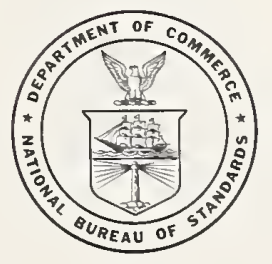

National Bureau of Standards. Monograph 27

Supplement 2

Issued April 28, 1967

Supersedes Supplement 1 to Monograph 27, Sept. 13, 1963 
This second supplement to National Bureau of Standards Monograph 27 has been combined with the references given in Supplement 1 (May 13, 1963) and issued as a single publication to assist the users of this material. 


\section{July 1960 to December 1962}

\section{Contents}

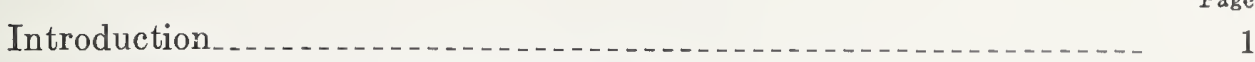

1. Thermoelectric theory and calibration $\ldots \ldots \ldots$

2. Thermoelectric devices . . . .

3. Resistance devices $\ldots \ldots \ldots \ldots$

4. Radiation devices_............. 7

5. Expansion devices $\ldots \ldots$

6. Aspirated devices $\ldots$

7. Other methods, descriptive articles_._. 10

8. Special applications, method not specified in title $\ldots \ldots \ldots \ldots$

9. Nuclear applications of temperature measurement_ _._. 12

10. Associated equipment and testing procedure

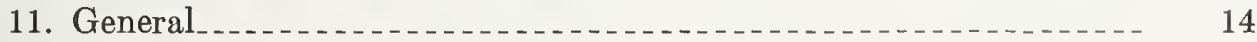

\section{January 1963 to December 1965}

\section{Contents}

Introduction

1. Theory, calibration and temperature scales $\ldots \ldots \ldots \ldots$

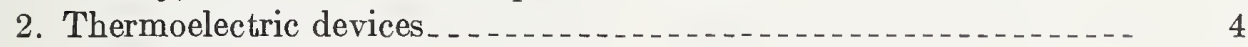

3. Resistance devices $\ldots$

4. Radiation devices $\ldots \ldots \ldots$

5. Expansion devices $\ldots$

6. Aspirated devices

7. Other methods, descriptive articles_........ 19

8. Special applications, method not specified in title $\ldots \ldots 22$

9. Nuclear applications of temperature measurement__._._. 25

10. Associated equipment and testing procedure

11. General 


\title{
Bibliography of Temperature Measurement
}

\author{
July 1960 to December 1962
}

\author{
Carl Halpern
}

(May 9, 1963)

\begin{abstract}
There are presented in this supplement to NBS Monograph 27, "Bibliography of Temperature Measurement, January 1953 to June 1960" issued April 6, 1961, about 700 additional references to the field of temperature measurement. The period covered is from July 1960 to December 1962 with some earlier references which came to our attention. The arrangement of material is the same as in Monograph 27, and the journal abbreviations used are those employed in Chemical Abstracts.
\end{abstract}

\section{Introduction}

The material contained herein was collected from two general sources: scientific and technical journals and reports of investigations sponsored or conducted by various governmental agencies. English, German, and French journals and translations in English of Russian journals were covered as well as the more commonly used abstract journals. Some references to material in other languages, obtained from the abstract journals, are also included. To obtain references to governmental reports the following were consulted: Technical Abstract Bulletin, Armed Services Technical Information Agency (ASTIA); U.S. Government Research Reports, Office of Technical Information, U.S. Department of Commerce; and Scientific and Technical Aerospace Reports, National Aeronautics and Space Administration (NASA). While reasonably complete coverage was intended, it is inevitable that oversights and other unintentional omissions have occurred.

\section{Thermoelectric Theory and Calibration \\ 1950}

Barber, C. R., The emf-temperature calibration of Pt, $10 \% \mathrm{Rh} \mathrm{Pt}$ and $\mathrm{Pt}, 13 \% \mathrm{Rh} \mathrm{Pt}$ thermocouples over the temperature range $0-1760^{\circ} \mathrm{C}$, Proc. Phys. Soc. (London) 63B, 492 .

\section{8}

Aikhenbaum, B. L., Changes in the testing system in the field of temperature measurement, Measurement Techniques No. 5, 547 (Sept.-Oct.).

Kurti, N., The absolute temperature scale at low temperatures, Z. Physik. Chem. (Frankfurt) 16, 281.

\section{9}

Astrov, D. N., A. S. Borovik-Romanov, M. P. Orlova, and P. G. Strelkov, Evolving a practical temperature scale in the region of $10-90^{\circ} \mathrm{K}$, Measurement Techniques No. 11,876 (Nov.).
Astrov, D. N., M. P. Orlova, P. G. Strelkov, and D. I. Sharerskaya, Comparison of low-temperature scales of platinum resistance thermometers, Measurement Techniques No. 8, 613 (Aug.).

Barber, C. R., New gas thermometer measurements over the range from $10^{\circ}$ to $90^{\circ} \mathrm{K}$ and the extension of the International Temperature Scale below $90^{\circ} \mathrm{K}$, Proc. Intern. Congr. Refrig., 10th, Copenhagen, 1959, 1, 174.

Bragin, B. K., A thermoelectric method of evaluating the purity of platinum for standard thermocouples, Measurement Techniques No. 10, 776 (Oct.).

Dzyuba, A. S., and P. B. Kantor, A semiconductor thermocryostat for calibration of standard thermometers, Measurement Techniques No. 11, 880 (Nov.).

Gertsriken, S. D., M. M. Novikov, and V. S. Kopan, Nature of the thermal electromotive force that arises from metal deformation, Ukrain. Fiz. Zh. 4, 293.

Kropschot, R. H., and F. J. Blatt, Thermoelectric power of cold-rolled pure copper, Phys. Rer. 116, 617.

Orlova, M. P., Reproducibility of the boiling temperature of oxygen, Measurement Techniques No. 5, 330 (May).

Pilipchuk, B. I., Units for the measurement of thermal quantities, Measurement Techniques No. 1, 26 (Jan.).

Swindells, J. F., Calibration of liquid-in-glass thermometers, Natl. Bur. Std. (U.S.) Circ. 600.

Usoltsev, V. A., Stability of the distillation temperature of carbon dioxide, Measurement Techniques No. 2, 118 (Feb.).

Yayshev, N. A., Approximation theory of the heat inertia of technical thermocouples and resistance thermometers, Nauch. Trudy Leningrad. Inst. Tochnoi Mekh. i Optiki 1959, No. $37,64-90$.

\section{0}

Berry, R. J., The reproducibility of the sulfur point. Can. J. Phys. 38, 1027 (Aug.).

Blatt, F. J., M. Garber, R. H. Kropschot, and B. Scott, Thermoelectric power of dilute copper and silver alloys, Australian J. Phys. 13, 223.

Blatt, F. J., and R. H. Kropschot, Thermoelectric power of dilute copper alloys, Phys. Rev. 118, 480.

Boerdijk, A. H., Diagrams representing states of operation of a general thermocouple, J. Appl. Phys. 31, 1141 (Juls).

Borovik-Romanov, A. S., M. P. Orlova, and P. G. Strelkor, Designing a practical temperature scale for the $10-90^{\circ} \mathrm{K}$ interval, Measurement Techniques No. 1, 42 (Jan.).

Bragin, B. K., Calibration of rare-metal thermocouples against the melting point of palladium, Measurement Techniques No. 12, 1019 (Dec.). 
Brickwedde, F. G., H. van Dijk, M. Durieux, J. R. Clement, and J. K. Logan, The "1958 $\mathrm{He}^{4}$ scale of temperatures," J. Res. Natl. Bur. Std. (U.S.) 64A, 1; Natl. Bur. Std. (U.S.) Monograph 10 (June 17).

Corruccini, R. J., Interpolation of platinum resistance thermometers, Rev. Sci. Instr. 31, 673 (June).

Costa, P., Determination of the thermoelectric power of uranium and plutonium, J. Nucl. Mater. 2, 75.

Danisherskii, S. K., Selection and calibration of tungsten and molybdenum wire for thermocouples, Measurement Techniques No. 5, 333 (June).

Donahoe, F. G., Theoretical bound on the thermoelectric figure of merit, Elec. Eng. 79, 488 (June).

Donde, Yu. Ya., and M. A. Pisarevskaya, The use of alternating currents for calibration commercial optical pyrometers, Measurement Techniques No. 9, 766 (Sept.)

Fink, E. W., An infrared radiation method for calibrating transient thermocouples, Westinghouse Electric Corp. Bettis At. Power Lab., Pittsburgh, WAPD-R (TH) -575 (Apr.).

Harrison, W. N., et al., Standardization of thermal emittance measurements, WADC Tech. Rept. 59-510, Pt I and II (Aug. 1959 and Nov. 1960).

Heusinkveld, W. A., Comparison of the temperature scales of various laboratories in the $600-3500^{\circ} \mathrm{C}$ range, Electrotechniek 38, 536 (Oct.).

Hughes, W. F., and E. W. Gaylord, Theoretical analysis of a dynamic thermocouple. II. The continuous area interface, J. Appl. Mech. 27, 259.

Kaufman, A. B., Temperature-probe response time, Instr. Control Systems 33, 804 (May).

Kirenkov, I. I., New thermodynamic temperature measurements of solidifying gold and zinc, Measurement Techniques No. 6, 493 (June).

Kirenkov, I. I., V. A. Kovalevskii, and G. A. Krakhmalnikova, Reproduction of the color-temperature scale by photometric methods, Measurement Techniques No. 2, 112 (Feb.)

Lewis, H. W., and J. R. Reitz, Efficiency of the plasma thermocouple, J. Appl. Phys. 31, 723.

Lougher, E. H., Measurement of the parameters in the thermoelectric figure of merit, Elec. Eng. 79, 358 (May).

McLaren, E. H., and E. G. Murdock, The freezing points of high purity metals as precision temperature standards, Can. J. Phys. 35, 1086 (1957) ; 36, 585, 1131 (1958); $38,100,577(1960)$.

MeNish, A. G., Temperature standards, Instr. Control Systems 33, 775 (May).

Meyer, G., and J. F. Oosterom, Calibration of millivoltmeters and thermoelements and the combination of the two, Rec. Trav. Chim. 79, 622 .

Müller, R. H., New precise temperature standard, Anal. Chem. 32, 123A (Sept.).

Myers, W. C., and R. T. Bate, Measure of figure of merit of thermoelectric materials, Rev. Sci. Instr. 31, 464 (Apr.).

Pearson, W. B., The thermoelectric power of annealed and cold-worked silver and gold at low temperature, Can. J. Phys. 38, 1048.

Pearson, W. B., Interpretation of relative thermoelectric phenomena at low temperature with special consideration of the effects of cold work on copper, Phys. Rev. $119,549$.

Plyukhin, B. I., Laws of the temperature radiation of a flame, Dokl. Akad. Nauk SSSR 131, 68.

Quandt, Jr., E. R., and E. W. Fink, Experimental and theoretical analysis of the transient response of surface-bonded thermocouples, U.S. At. Energy Comm. WAPD-BT-19.

Roeser, W. F., Calibrating thermocouples, Instr. Control Systems 33, 796 (May)

Schindler, A. I., and R. J. Smith, Low temperature dependence of the electrical resistivity and thermoelectric power of palladium and palladium nickel alloys containing absorbed hydrogen, PB 146217 (LC) (Oct.).

Sharevskaya, D. I., and P. G. Strelkov, Thermometric platinum resistivity in the region of liquid helium temperatures, Measurement Techniques No. 12, 1023 (Dec.).

Sharevskaya, D., et al., Differences in the relation between resistance and temperature of several grades of platinum in the range of 10.8 to $273.16^{\circ} \mathrm{K}$, Measurement Techniques No. 7, 598 ( July).

van Dijk, H., The 1958 scale of temperatures for the liquid helium-4 region, Progr. Cryog. 2, 121.

Williams, S. B., Triple-point-of-water temperature reference, Instr. Control Systems 33, 1918.

Wilson, R. E., Temperature standards, Instr. Control Systems 33, 770 (May).

Temperature calibration survey, Instr. Control Systems 33, 778 (May).

\section{1}

Bauerle, L. E., Analysis of "immersed" thermocouple error, Rev. Sci. Instr. 32, 313 (Mar.).

Boerdijk, A. H., Zero-, first-, and second-order theories of a general thermocouple, J. Appl. Phys. 32, 1584 (Aug.).

Bowley, A. E., et al., Measurement of the figure of merit of a thermoelectric material, J. Sci. Instr. 38, 433 (Nov.).

Bragin, B. K., A normal platinum thermal electrode, Measurement Techniques No. 7, 596 (Feb.).

Bragin, B. $\bar{K}$., Certain errors in checking commercial resistance thermometers, Measurement Techniques No. 3, 194 (Mar.)

Bragin, B. K., Errors in the calibration of technical resistance thermometers, Izmeriteln. Tekhn. No. 3, 17.

Crawford, G. J. B., Note on the measurement of the figure of merit of thermoelectric materials and of refrigerating junctions, Rev. Sci. Instr. 32, 353.

Gordor, A. N., and B. I. Kovsher, Nature of dynamic errors in measuring pulsating temperatures of a gas flow with a pulsating speed, Measurement Techniques No. 5, 363 (May)

Haas, A., Calibration of contact surface thermometers, Acta Imeko, 91.

Haase, R., K. Hoch, and H. Schouert, Thermocouples. VI. Evaluation of the measurements, Z. Physik. Chem. (Frankfurt) 27, 421.

Jones, T. P., On the accuracy of realization of the international temperature seale above $1063^{\circ} \mathrm{C}$, Australian J. Appl. Sci. 12, 141 (June).

Kennedy, G. C., and R. C. Newton, Effect of pressure on the electromotive force of a platinum-bismuth thermocouple, J. Geophys. Res. 66, 1491.

Krikorian, O. H., Optical pyrometer calibration with a standard carbon arc, Proc. Instr. Soc. Am. 16, Paper No. 151-LA-61.

Madison, J. H., Calibration of Chromel-Constantan thermocouples for nuclear heat rate sensors, General Electric Co., Aircraft Nucl. Propulsion Dept., Cincinnati, TID-11927 (Jan. 23).

Maulard, J., The theoretical determination of the response time of a thermometric probe, Rech. Aeron. No. 83, 41 (July).

Moser, H., Thermodynamic temperature scale, its realization between $90^{\circ}$ and $1500^{\circ} \mathrm{K}$, Pure Appl. Chem. 2, 167 .

Oleinik, B. L., New regulations on the international practical temperature scale, Measurement Techniques No. 7 , 538 (July).

Orshanskii, D. L., On very high temperatures, the physical basis of their concept and their measurement, Acta Imeko, 136.

Prinz, W., Indication delay and indication error functions of thermometers. The significance of the half value time and nine tenths value time of thermometers, Allgem. Waermetech. 10, 85 .

Reich, A. D., and J. R. Madigan, Transient response of a thermocouple circuit under steady currents, J. Appl. Phys. 32, 294 (Feb.).

Roy, J., and G. Gohard, "Fixed point" apparatus for thermocouple calibration, Mesur. Control Ind. 26, 269 (Mar.). 
Sharevskaya, D. I., and P. G. Strelkov, Methods for calibrating against the practical temperature scale in the region of $10-90^{\circ} \mathrm{K}$, Measurement Techniques No. 2, 110 (Feb.).

Shpiegelman, E. S., Utilization of aluminum for calibrating first-grade thermometers, Measurement Techniques No. 5,405 (Jan.).

Stimson, H. F., International practical temperature scale of 1948. Text revision of 1960, Natl. Bur. Std. (U.S.) Monograph 37 (Sept. 8).

Stimson, H. F., International practical temperature scale of 1948, J. Res. Natl. Bur. Std. (U.S.) 65 A, 139.

Suzuki, M., Temperature standard below an oxygen point, Res. Electrotech. Lab., Tokyo, No. 615 (Sept.).

Tingwaldt, C., Thermodynamic temperature scale, its realization in solid bodies for temperatures above $1500^{\circ}$. K, Pure Appl. Chem. 2, 173.

Toenshoff, D. A., Automatic calibration of thermocouples, Engelhard Inds. Tech. Bull. 2, 88 (Dec.).

van Dijk, H., The thermodynamic temperature scale and its realization below $90^{\circ} \mathrm{K}$, Pure Appl. Chem. 2, 157.

Wagner, N. K., Theoretical time constant and radiation error of a rocketsonde thermistor, J. Meteorol. 18, 606 (Oct.).

Calibration of optical pyrometers, Glass Ind. 42, 638 (Nov.).

Calibration of optical pyrometers, Natl. Bur. Std. (U.S.) Tech. News Bull. 45, 184 (Nov.).

Calibration of optical pyrometers, Instr. Pract. 15, 1558 (Dec.).

Calibration of platinum resistance thermometers, Engineer 211, 1048.

Calibration of platinum resistance thermometers, Instr. Pract. 15, 863 .

Calibration of platinum resistance thermometers, Natl. Bur. Std. (U.S.) Tech. News Bull. 45, 62 (Apr.).

How to calibrate thermocouples to high accuracies, Space/ Aeronautics 35, 89 ( Мay).

Ice point standardization mercury-in-glass thermometers, $\mathrm{Bu}$ Weps-Bu Ships Calibration Program, Secondary standards laboratory measurement system operation procedure, NT-01, PB 171725.

The international practical temperature scale, Natl. Bur. Std. (U.S.) Tech. News Bull. 45, 65 (Apr.).

Thermocouple calibration, Natl. Bur. Std. (U.S.) Tech. News Bull. 45, 44 (Mar.).

Thermocouple calibration, Electron. Ind. 20, 231 (Mar.). Thermocouple calibration, Instr. Pract. 15, 428 (Apr.).

Thermocouple calibration, Instr. Control Systems 34, 1663 (Sept.) .

Triple point of water standardization, Bu Weps-Bu Ships Calibration Program, Secondary standards laboratory measurement system operation procedure NT-04, PB 171726.

\section{2}

Barber, C. R., The establishment of a practical scale of temperature for the range $10-90 / K$, Brit. J. Appl. Phys. 13, 235 (May).

Berry, R. J., A precision oxygen point calibration bath, Can. J. Phys. 40, 859 (July).

Blackburn, G. F., and F. R. Caldwell, Reference tables for 40 percent iridium-60 percent rhodium versus iridium thermocouples, J. Res. Natl. Bur. Std. (U.S.) 66C, I (Jan.-Mar.).

Bussard, R. W., Some considerations of dynamic behavior in the plasma thermocouple, J. Appl. Phys. 33, 606 (Feb.).

Davis, J., and G. Lanza, Conventional and plasma thermoCouples, U.S. Air Force, Office of Aerospace, Res, AFCRL 62-630 (June 5).

Freeze, P. D., F. R. Caldwell, and E. R. Davis, Reference tables for the palladium vs platinum-15 percent iridium thermocouple, ASD-TDR-62-525 (Dec.) ; ASTIA AD295607.

Kelly, G. D., How to calibrate optical pyrometers, Ceram. Ind. 79, 64 (Oct.).
Krikorian, O. K., Optical pyrometer calibration with a standard carbon arc, ISA Trans. 1, 273 (July).

Lovejoy, D. R., Temperature scales above $1000^{\circ} \mathrm{C}$, Pure Appl. Chem. 5, 565.

Myers, H. S., Convenient laboratory temjerature standard, Chem. Eng. 69, 192 (Mar.).

Obrowski, W., and W. Prinz, Determination of basic values for the thermocouples Pt 30\% Rh-Pt 6\% Rh, Arch. Eisenhuettenw. 33,1 .

Thorn, R. J., and G. H. Winslow, Contribution to the realization of the visual optical pyrometer temperature scale, Rev. Sci. Instr. 33, 961 (Sept.).

Zholkov, Yu. A., Thermal inertia of thermocouples, Measurement Techniques No. 12, 938 (June).

Calibration of optical pyrometers, Instr. Control Systems 35, 84 (May).

Reference tables for iron $\nabla$ constantan thermocouples, Brit. Std. Inst., B. S. 1829.

The thermodynamic and practical temperature scales, R \& D No. 15, 40 (Nov.).

\section{Thermoelectric Devices}

\section{9}

Steven, G., and W. C. Troy, The mechanical protection of the W/Ir thermocouple, PB 138320 (LC), (June).

\section{0}

Steven, G., and W. C. Troy, The development of thermocouples for temperatures in the region of $1600^{\circ}$ to $2000^{\circ} \mathrm{C}, \mathrm{PB} 137512$ (LC), (Sept.).

\section{6}

Haase, G., and G. Schneider, Thermoelements from the rhenium-iridium system, U.S. At. Energy Comm. AECtr-3835.

\section{7}

Matton, G., and C. Fouré, Thermoelectric probes for measuring high temperatures in gas streams : their application to the study of flames stabilized by obstacles, 6th Symposium (International) on Combustion, New Haven, Conn., 757, Reinhold Pub. Corp.

\section{8}

Danisherskii, S. K., The immersion of thermocouples, Ind. Lab. 24, 1608.

Ergardt, N. N., Stability of platinum-rhodium/platinum thermocouples, Trudy Vsesoyuz, Nauch.-Issledovatel. Inst. Metrol. 1958, No. 35, 87.

Gordov, A. N., and N. N. Ergardt, Some causes of errors in the measurement of temperatures by means of thermocouples, Ind. Lab. 24, 1605.

Kislyi, P. S., and G. V. Samsonov, High temperature semiconductor thermocouples, Izv, Akad. Nauk, SSSR, Otd. tekh. Nauk, Metall. Tople. 6, 135 (Nov.-Dec.).

Mejers, M. N., Irradiation study of platinum and platinum-rhodium thermocouple wire, U.S. At. Energy Comm. DC-58-5-730.

Sitnitskii, Yu. I., Dynamic characteristics of rapidly acting thermocouples, Avtomatika, Akad. Nauk Ukr. R.S.R. 1958, No. 1,85 .

\section{9}

Altshuler, Y. A., Z. I. Bakushchik, and B. G. Klikshtein, Temperature measurement of rotating surfaces, Priborostroenie 1959, No. 5, 24.

Hartley, J. J., Thermal electromotive force of copperconstantan thermocouples as a function of junction fabrication, U.S. At. Energy Comm. SCTN-373-59(16).

obrowski, W., Temperature measurement with thermoelements, Dechema Monograph 35, No. 528-55, 203.

Ogorodnikov, N. N., and V. Ya. Lerin, Use of instruments with thermal inertia compensation for measurement of rapidly changing temperature in gases, Trudy KubJshev. A visto. Inst. 1959, No. 8, 65. 
Potts, J. F., and D. L. McElroy, Some results of basemetal thermocouple research at Oak Ridge National Laboratory, U.S. At. Energy Comm. TID-7856, Pt. 1.

Rudnitskii, A. A., Noble metal thermocouples for measuring high temperatures, Issledovaniya po Zhaproch. Splavam. Akad. Nauk, SSSR, Inst. Met. im. A. A. Baikova 4, 380.

Rudnitskii, A. A., Thermocouple measurement of high temperatures during steel manufacture, Fiz.-Khim. Osnovy Proizv. Stali, Akad. Nauk, SSSR, Inst. Met., Tr. 5-oi Konf. 1959, 311.

Serota, A. M., and B. K. Maltser, A gold-platinum thermocouple, Measurement Techniques No. 8, 611 (Aug.).

Sukhov, S. A., S. Ya. Kadletz, and G. D. Pavlyuk, Investigation of electrolytic thermocouples, Measurement Techniques No. 2, 121 (Feb.).

Shiba, K., Thermoelectric thermometer of noncontacting type, Oyo Butsuri $28,422$.

Tomizaroa, K., and T. Ushijama, Measurement of surface temperature by $\mathrm{Cu}-\mathrm{Co}$ (Constantan) thermocouple, Denkisik iho 23, 586 .

\section{0}

Accinno, D. J., and J. F. Schneider, Platinel- a noble metal thermocouple to replace Chromel-Alumel, Engelhard Ind., Tech. Bull. 1, 53 (Sept.) .

Anderson, A. R., and D. J. Mackenzie, Materials for high (2500-4000 deg. F) gas engine temperature measurements, Aircraft Eng. 32, 201 (July).

Barrows, H., and D. J. Ryley, Temperature recovery factors in steam, Engineer 209, 903.

Bennet, H. E., The Pallador thermocouple, Platinum Metals Rev. 4, 66 (Apr.).

Berezin, G. F., A simple and highly sensitive thermocouple battery for the measurement of body surface temperature, Ind. Lab. 25, 502 (Apr.).

Blue, M. D., Thermoelectric effects in coppes-gold alloys, Phys. Rev. 117, 137.

Boudreaux, R. A., Induced thermal error for thermocouples attached to thin plates, General Electric Co. Aircraft Nucl. Propulsion Dept., Cincinnati, DC-60-545 (May 9)

Chandler, R. L., and E. J. Dent, Temperature compensated strain gauges, Electron. Eng. 32, 414 (July).

Christy, R. W., Electric conductivity and thermoelectric power in ionic crystals, Am. J. Phys. 28, 457 (May).

Davisson, J. W., et al., Thermoelectricity, NRL Mem. Rept. 1089 (Aug.) ; PB 161977 (Dec.)

Edwin, B., Recent developments in nickel/nickel-chromium thermocouples, Elektrowärme 18, 222 (July).

Edwin, B. E., New developments in Ni/Ni-Cr thrmocouples, Eng. Dig. 21, 88 (Nov.).

Eller, H. C., and J. B. Stewart, Connect thermocouples firmly to burner tip, Elec. World 154, 45 (Sept. 5 ).

Haig, L. B., Thermocouple probe design method, Abstract : S.A.E. J. 68, 81 (Aug.).

Heath, J. H., High temperature thermocouples, Part I, United Kingdom At. Energy Admin. Rept. AEEW-R-141 (Dec.).

Jordan, H. C., Welded thermocouple Junctions, Instr. Control Systems 33, 988 (June).

Krivka, H. A., Make your own thermocouples, Machine Design 32, 184 (June 9).

Kröckel, O., New thermocouple for high-temperature measurements, Silikat Tech. 11, 108.

Krol, L. Ya., et al., Thermocouples from intermetallic compounds, Zn Sb and $\mathrm{Cd} \mathrm{Sb,} \mathrm{Instr.} \mathrm{Construct.} \mathrm{No.}$ 8, 33 (Aug.).

Kuether, F. W., and J. C. Lachman, How reliable are the two new high-temperature thermocouples in vacuum, ISA J. 7, 67 (Apr.).

Lachman, J. C., Refractory metal thermocouples, Abstract : Metal Progr. 78, 161 (Aug.).

Lacroix, R., Platinum-rhodium/platinum thermocouples, Bull. Soc. Franc. Ceram. No. 48, 19.

Levin, E. D., A thermocouple for measuring the top layer temperature of a coke mass, Ind. Lab. 25, 503 (Apr.).
Mekheev, V. S., Some sources of error in measuring temperatures with thermocouples, Ind. Lab. 26, 691 .

Ongkiehong, L., and J. van Duijn, Construction of a thermocouple for measuring surface temperatures, J. Sci. Instr. 37, 221 (June).

Parrott, J. E., The interpretation of the stationary and transient behavior of refrigerating thermocouples, Solid State Electron, 1, 135 ( May).

Raezar, S. D., and H. L. Olsen, The intermittent thermometer: a new technique for the measurement of extreme temperature, Johns Hopkins Univ., Silver Spring, Md., Appl. Phys. Lab. NP-11314 (Dec.).

Rudnitskii, A. A., and I. I. Tyurin, A search for alloys suitable for high temperature thermocouples, $\mathbf{Z h}$. Neorgan. Khim. 5, 401 (Feb.).

Short, W. W., and B. H. Sage, Temperature measurements in a spherical field; transfer coefficients and corrections for thermocouples in boundary flow, A.I.Ch.E. J. 6, 163 (Mar.).

Shoults, D. R., Aircraft nuclear propulsion program brings useful byproducts, S.A.E. J. 68, 35 (Apr.).

Stevenson, J. A., The metal-clad thermocouple, Platinum Metals Rev. 4,127 (Oct.).

Stover, C. M., Method of butt welding small thermocouples 0.001 to 0.010 inch in diameter, Rev. Sci. Instr. 31, 605 (June).

Walker, J. E. C., and R. E. Wells, Thermometry of respired air, J. Appl. Physiol. 15, 541.

West, E. D., Techniques in calorimetry: noble-metal thermocouples for differential use, Rev. Sci. Instr. 31, 896.

Yazliev, S., An investigation of the thermoelectric properties of nickel-palladium alloys, Zh. Neorgan. Khim. 5, 2446.

Expendable immersion thermocouple, Mech. Eng. 82, 77 (Sept.).

Hi-temp thermocouples bend to fit test parts, Prod. Eng. 31, 9 (Dec. 5 ).

Kanthal base metal thermocouple wire, Ind. Heating 27, 637.

Soviet thermocouple is sensitive, Chem. Eng. News 38, 44 (Aug. 1).

Thermocouple measures temperatures of molten metal, J. Franklin Inst. 269, 428 .

Thermocouples for low temperature application, Electronics 33,85 (Nov. 4 ).

Tungsten vs tungsten 74 rhenium 26 thermocouple, Englehard Ind. Tech. Bull. 1, 56 ( Sept.).

Where to get the new high-temperature thermocouple materials, ISA J. 7, 66 (Apr.).

\section{1}

Arai, T. T., and J. R. Madigan, Response of a thermocouple circuit to non-steady currents, J. Appl. Phys. 32, 609 (Apr.).

Bard, J. A., Thermocouples for high temperatures, Instr. Control Systems 34, 1874 (Oct.).

Bennett, H. E., The contamination of platinum metal thermocouples, Platinum Metals Rev. 5, 132 (Oct.).

Boggs, B. C., Common parallel thermocouples for average temperature measurement, WADD TR-60-650; ASTIA AD-255 753.

Bostwick, W. E., Thermocouple loading-an exercise in impedance matching, Instr. Control Systems 34, 863 (May).

Bradley, D., and A. G. Entwistle, Determination of the emissivity, for total radiation, of small diameter platinum-10\% rhodium wires in the temperature range $600-1450^{\circ} \mathrm{C}$, Brit. J. Appl. Phys. 12, 708 (Dec.).

Brands, F. W., Two hot junctions up thermocouple output, Electronics 34,118 (Apr. 28).

Bundy, F. P., Effect of pressure on emf of thermocouples, J. Appl. Phys. 32, 483 (Mar.).

Burnett, D. R., Transient temperature measurement errors in heated slabs for thermocouples located at the insulated surface, J. Heat Transfer 83, 505. 
Cutler, M., Thermoelectric measurements at small-area contacts, J. Appl. Phys. 32, 1075.

Darling, A. S., Thermoelectric properties of rhodiumplatinum alloys, Instr. Control Systems 34, 861 (May).

de Percin, F., Some observations of the effect of direct and snow-reflected solar radiation on exposed and shielded thermocouples, Quartermaster Research and Engineering Center, Natick, Mass., Study Rept. RER-19 (Apr.) ; PB 152070 (Jan.).

Emelhanenko, O. V., and F. P. Kesamanly, Concerning a rapid method of precise measurements of thermal emf of semiconductors, Soviet Phys.: Solid State 2, 1356 (Jan.).

Franks, E., High-temperature thermocouples using nonmetallic members, Abstract: Electro-Technol. (New York) 68, 12 (July).

Glawe, G. E., R. C. Johnson, and L. N. Krause, A cocledtube pyrometer with experimental results obtained in a high-temperature gas stream, NASA Tech. Note D-870.

Fill, J. S., The use of Fibro platinum in thermocouple elements, Engelhard Inds. Tech. Bull. 2, 85 (Dec.).

Hsu, S. T., and F. W. Smidt, Measured variations in local surface temperatures in pool boiling of water, Trans. ASME C83, 254 (Aug.).

Johnson, W., Temperature measurement in high-temperature X-ray powder cameras, J. Sci. Instr. 38, 373.

Kelley, M. J., et al., Effect of nuclear radiation on thermocouples, Abstract: Electro-Technol. (New York) 68, 11 (July).

Kislyi, P. S., and G. V. Samsonov, High-temperature thermoelements from semiconductors, Planseeber. Pulvmet 8, 200.

Kislyi, P. S., el al., Thermoelectric characteristics of hightemperature thermocouples with electrodes made of high melting point alloys, Measurement Techniques No. 5, 366 (May).

Lachman, J. C., New developments in tungsten/tungstenrhenium thermocouples, Proc. Instr. Soc. Am. 16, Paper No. 150-LA-61.

Lachman, J. C., Thermocouples for ultrahigh temperatures, Metal Progr. 80, 73 (July).

Lachman, J. C., and J. A. McCurty, Use of refractory metals for high temperature thermocouples, Abstract: Electro-Technol. (New York) 68, 11 (July).

Lowell, H. H., H. W. Allen, and J. E. Jenkins, Electrical characteristics of four ternary platinum-rhodium-base alloys containing chromium, cobalt, or ruthenium, NASA Tech. Note $\mathrm{D}-867$.

Lutz, O., and F. von Burger-Scheidlin, Point-by-point determination of very high temperatures, Deutch. Forsch. Anst. Luft. Ber., 147.

McCarhty, D. E., Response characteristics of a radiation thermocouple at various pressures, J. Opt. Soc. Am. 51,801 .

Moffat, R. J., Gradient approach to thermocouple circuitry, Abstract: Electro-Technol. (New York) 68, 12 (July).

Nadler, M. R., and C. P. Kempter, Thermocouples for use in carbon atmospheres, Rev. Sci. Instr. 32,43 (Jan.).

Obrowski, W., Thermoelements, Arch. Tech. Messen, 183 (Aug.).

Potts, J. F., and D. L. McElroy, Basic studies on basemetal thermocouples, Abstract: Metal Progr. 80, 162 (Apr.).

Powell, R. L., M. D. Bunch, and L. P. Caswood, Lowtemperature thermocouple thermometry, Advan. Cryog. Eng. 6, 537.

Powell, R. L., M. D. Bunch, and R. J. Corruccini, Low temperature thermocouples-I. Gold-cobalt or constantan versus copper or "normal" silver, Cryogenics 1, 139 (Mar.).

Powell, R. L., and L. P. Caywood, Low temperature characteristics of some commercial thermocouples, Advan. Cryog. Eng. 7, 517.

Sagoschen, J., Temperature measurements with thermocouples of platinum group metals, Metall. 15, 34.

Salva, S. J., Calculate change in resistance of thermocouple wire, Power 105, 96 (Feb.).
Samsonor, G. V., P. S. Kislyi, and A. D. Panusvuk, Thermoelectric properties of thermocouples with highmelting solid electrodes, Measurement Techriques No. 10, 810 (Oct.).

Scadron, L., Ceramic-insulated thermocouples, Instr. Control Systems 34, 856 (May).

Sirs, J. A., Measurement of rapid temperaturc changes by thermocouples, J. Sci. Instr. 38, 489 (Dec.).

Smith, E. C., Swaged MgO thermocouples, Instr. Control Systems 34, 858 ( May).

Sochor, B., Instruments and methods for measuring thermal quantities, Acta Imeko, 161.

Stover, C. M., Method of making small pointed thermocouples, Rev. Sci. Instr. 32, 366 (Mar.).

Tau, K., and M. Boudart, Recombination of atoms at the surface of thermocouple probes, Can. J. Chem. 39, 1239.

Temme, M. I., and W. H. Giedt, Dual probe for high-temperature-gas measurements, U.S. At. Energy Comm. Rept. ARI 174 (Dec. 1961) ; ASTIA AD-274 352.

Weiss, H., An apparatus for the measurement of tcmperatures, using thermocouples, in high speed rotating machines, Elektrotech. Z. 13B, 353 (June 26).

Wong, P., and P. S. Schaffer, Development of a tungsten/ molybdenum immersion thermocouple for measuring molten metal temperatures in vacuum, ASTIA AD-253 949 (Apr.).

A thermocouple for the surface of high-speed cylinders, Eng. Mater. and Design 4, 599 (Sept.).

New thermocouple up to 4200F, Metalworking Prod. 105, 83 (Sept. 20).

Recent advances in thermocouple technolog 5 , ElectroTechnol. (New York) 68, 11 (July).

Thermocouple alloy for 5000F, Mater. in Design Eng. 54,13 (Sept.)

Thermocouples for high temperature, Nucl. Power 6, 70 (June)

Thermocouples, base metal (except copper-constantan) ambient to $1100^{\circ} \mathrm{C}, \mathrm{Bu}$ Weps-Bu Ships Calibration Program. Standards lab. Measurement system operation NT-05 (Oct. 25) ; PB 181147.

\section{2}

Baas, P. B. R., Effect of oxide finish on nickel alloy thermocouple wires, S.A.E. Paper 524H ; Abstract S.A.E. J. 70, 102 (Sept.).

Bansal, T. D., Copper-Advance thermocouples in the temperature range $0-100^{\circ} \mathrm{C}$, J. Sci. Ind. Res. (India) 21D, 23 (Jan.).

Beck, J. V., Thermocouple temperature disturbances in low conductivity materials, Trans. ASME $84 \mathrm{C}, 124$ (May).

Benson, J. M., and R. Horne, Surface temperature of thin sheets and filaments, Instr. Control Systems 35 , 115 (Oct.).

Bostwick, W. E., A note on platinum/platinum-rhodium thermocouple uncertainty, Trans. Inst. Radio Engrs. NS-9, 253 (Jan.).

Caldwell, F. R., Thermocouple materials, Natl. Bur. Std. (U.S.) Monograph 40 (Mar. 1).

Chin, J. H., Effect of uncertainties in thermocouple location on computing surface heat fluxes, ARS J. 32, 273.

Clark, R. B., Time-temperature effect on jet engine thernocouple accuracy and reliability, S.A.E. Paper 524K; Abstract: S.A.E. J. 70, 102 (Sept.).

Davenport, M. E., et al., Thermocouple attachment to a direct-current heater, Trans. ASME 84C, 124 (May).

Denison, J. W., Technique to construct fine wire thermocouples, Rev. Sci. Instr. 33, 870 (Aug.).

Dreisner, A. R., et al., High temperature $W / \mathrm{W}-25$ Re thermocouples, Instr. Control Systems 35, 105 (May).

Faul, J. C., Thermocouple performance in gas streams, Instr. Control Systems 35, 104 (Dec.).

Freeze, P. D., and L. O. Olsen, Thermoelectric and mechanical stability of Platinel II thermocouples in oxidizing atmospheres, ASD-TDR-62-835 (Nor.). 
Hadfield, D., Immersion pyrometry and open hearth furnace productivity, Platinum Metals Rev. 6, 1 (Jan.).

Hahn, P. M., Evaluation of spring-loaded thermocouple probes under transient temperatures, Mater. Res. Std. 2, 403 (May).

Hawley, S. A., J. E. Breyer, and F. Dunn, Fabrication of miniature thermocouples for uhf acoustic detectors, Rev. Sci. Instr. 33, 1118 (Oct.).

Heyne, W., Precision measurements in examining the relation between thermal e.m.f. and temperature of Pt$\mathrm{Rh} / \mathrm{Pt}$ thermocouples by comparison with a normal thermocouple, Feingerätetech. 11, 400 (Sept.).

Jackson, P. L., Use of a large thermocouple junction to locate temperature disturbances, Rev. Sci. Instr. 33, 334 (Mar.).

Kislyi, P. S., Prospects of utilizing refractory compounds for high temperature thermocouples, Poroshkovaya Met., Akad. Nauk SSSR 2, No. 4, 50.

Lachman, J. C., Coaxial thermocouple viewed as improvement, Abstract: S.A.E. J. 70, 128 (July).

Lachman, J. C., High temperatures thermocouples using tungsten-rhenium alloy tubing, S.A.E. Paper 524D, Abstract: S.A.E. J. 70, 102 (Sept.).

Lachman, J. C., New developments in W/W-RE (tungsten/tungsten rhenium) thermocouples, ISA Trans. 1, 340 .

Ling, F. F., and T. E. Simkins, Measurement of point-wise junction condition of temperature at the interface of two-bodies in sliding contact, ASTIA AD-283 932.

MacKenzie, D. J., and M. D. Scadron, Selection of thermocouples for high gas temperature measurement, S.A.E. Paper 524E, Abstract: S.A.E. J. 70, 102 (Sept.).

Olsen, L. O., Catalytic effects of thermocouple materials, ASD-TDR-62-304; ASTIA AD-284 880; S.A.E. Paper 524G, Abstract: S.A.E. J. 70, 94 (May).

Patzke, H., A new vacuum-thermocouple made by VEB Carl Zeiss Jena, Jena Rev. No. 1, 32.

Stewart, P. J., Study of temperature distribution with rhodium-platinum thermocouple probes, Platinum Metals Rev. 6, 126 (Oct.).

Walker, B. E., C. T. Ewing, and R. R. Miller, Thermoelectric instability of some noble metal thermocouples at high temperatures, Rev. Sci. Instr. 33, 1029 (Oct.).

Walker, B. E., C. T. Ewing, and R. R. Miller, Thermoelectric instability of some noble metal thermocouples at high temperatures, U.S. Naval Res. Lab., Washington, D.C., Rept. 5792 (June 29) ; ASTIA AD-282 154.

White, F. J., Accuracy of thermocouples in radiant-heat testing, Exp. Mech. 2, 204 (July)

Wolfe, R., and J. H. Wernick, Thermoelectric devices and materials, Bell Lab., Record 40, 190 (June).

Wormser, A. F., and R. A. Pfuntner, Thermocouple tells temperature above its melting point, S.A.E. J. 70, 56 (May).

Zenin, A. A., Errors in the readings of thermocouples passed through flames, Inzh. Fiz. Zh. 5, 68 (May).

A rhodium-platinum thermocouple for high temperature, Platinum Metals Rev. 6, 96 (July).

Gage eliminates surface heat loss, Missiles and Rockets 11, 36 (Dec. 3 ).

How and when precious metal thermocouples should be used, R \& D, 45 (Jan.).

\section{Resistance Devices}

\section{5}

Hotta, H., Substitute for platinum/platinum-rhodium thermocouples, Kinzoku 25, 459.

1957

Ciborowski, F., Influence of epitemperature of thermistors on temperature measuring, Pomiary, Automat., Kontrola 3, No. 3, 105.
Estrin, B. S., and P. B. Kantor, Temperature measure ment in the range of $300-500^{\circ} \mathrm{C}$, Measurement Techniques No. 10 , 774 .

Grashdankina, N. P., L. I. Domanskaya, and A. K. Kikrin, Measurements of temperature in high-pressure chambers by means of thermistors, Measurement Techniques No. $10,771$.

Manassi, V., The measurement of temperature with electric resistance thermometers, Elletrotecnica 46, 503 (Aug. 10).

\section{0}

Ambler, E., and H. Plumb, Use of carbon resistors as low temperature thermometers in the presence of stray r.f. (radio frequency) fields, Rev. Sci. Instr. 31, 656.

Barber, C. R., Resistance thermometers for low temperatures, Progr. Cryog. 2, 147.

Belinskii, L. I., and A. I. Pilorskii, Semiconductor thermometer, Instr. Construct. No. 10, 25 (Oct.)

Christiansen, W. H., The use of fine unheated wires in shock tubes, Phys. Fluids 3, 1027.

Gniewek, J. J., and R. J. Corruccini, Oarbon resistance thermometry with mixed dc and rf currents, Rev. Sci. Instr. 31, 899 .

Herr, A. C., H. G. Terbeck, and M. W. Tiefermann, Suitability of carbon resistors for field measurements of temperatures in the range of $35^{\circ}$ to $100^{\circ} \mathrm{R}$, NASA Tech. Note D-264 (Feb.).

Kostryukov, V. N., Platinum thermometer for calorimetric work, Instr. Exp. Tech. No. 6, 978 (Sept.).

Leslie, W. H. P., J. J. Hunter, and D. Robb, Precision temperature measurement outside the laboratory, Research 13, 250 ( July).

Lockett, O. J., A clinical thermometer, Lancet 1, 1391.

Lowenthal, G. C., and A. F. A. Harper, Resistance-temperature relationship of platinum at low temperatures and its infuence on precision thermometry, Brit. J. Appl. Phys. 205 (May).

Norton, H. N., Resistance elements for missile temperatures, Instr. Control Systems 33, 922 (June).

obrowski, W., Platinum resistance thermometer for high temperatures, Platinum Metals Rev. 4, 102.

Pavlova, I. A., The use of semiconductor thermometers for measuring low temperatures, Proc. Intern. Congr. Refrig., 10th, Copenhagen 1959, 1, 410.

Perelshina, A. P. The results of an experimental investigation of thermoelectromotive force in thermistors, Inzh. Fiz. Zh. 3, 119 (Apr.).

Rogers, G. B., and F. A. Raal. Semiconducting diamonds as thermistors, Rev. Sci. Instr. 31,663.

Rose, V. W., Resistance temperature detector, Instr. Control Systems 33, 790 (May).

Sharven, Yu. V., Anthracite coal thermometers for various temperature ranges, Instr. Exp. Tech. No. 1, 153 (Jan.).

Smith, R. W., An evaluation of thermistors: thermally sensitvie semiconductors, General Motors Eng. J. 7, 14 (Oct.).

Sterling, P. H., and H. Ho, Modern trends in resistance thermometry, Ind. Eng. Chem. 52, 59A (July).

Blue diamonds make rugged thermistors, Electronics 33, 78 (Aug.).

Platinum resistance thermometers, ISA J. 7, 60 (Aug.).

Resistance thermometer claimed accurate to $1560^{\circ} \mathrm{F}$, Prod. Eng. 31, 9 (Aug. 29).

What do you know about platinum resistance thermometers, ISA J. 7, 60 (Aug.).

\section{1}

Anderson, A. R., and T. M. Stickney, Ceramic resistance thermometers as temperature sensors above $2200^{\circ} \mathbf{R}$, Instr. Control Systems 34, 1864 (Oct.).

Ballard, H. N., Response time of and effects of radiation on the VECO bead thermistor, Proc. Instr. Soc. Am. 16. Paper No. 159-LA-61. 
Barber, C. R., and W. W. Blanke, A platinum resistance thermometer for use at high temperatures, J. Sci. Instr. 38, 17 (Jan.).

Bird, F. F., and W. E. Jackson, Accuracy in resistance thermometer measurements, Proc. Instr. Soc. Am. 16, Paper No. 157-LA-61.

Edlow, M. H., and H. H. Plumb, Reproducibilities of carbon and germanium thermometers at $4.2^{\circ} \mathrm{K}$, Advan. Cryog. Eng. 6, 542 .

Flanagan, C. D., Continuous recording temperature measurement by resistance, Electro-Technol. (New York) 67, 158 (Apr.).

Gogin, Yu. N., A resistance thermometer made from a sparking plug, Measurement Techniques No. 5, 411 (Jan.).

Hornung, E. W., and D. N. Lyon, Characteristics of several carbon thermometer-heaters at low temperature and in magnetic fields to 100 kilogauss, Rev. Sci. Instr. 32, 684 (June).

Kachurin, L. G., Checking the sensitivity of differential resistance thermometers in unbalanced bridge circuits, Measurement Techniques No. 7, 603 (Feb.).

Kaganov, M. A., and Yu. L. Rozenshtok, Utilization of thermistors for correcting differential temperaturedifference measuring circuits, Measurement Techniques No. 9, 712 (Sept.).

Kozhukh, V. Ya., Automatic measurement of small temperature differences, Measurement Techniques No. 11, 887 (Nov.).

Lindenfeld, P., Tests and comparison of carbon and germanium thermometers, Rev. Sci. Instr. 32, 9 (Jan.).

Low, F. J., Gallium-doped germanium resistance thermometers, Advan. Cryog. Eng 7, 514.

Low, F. J., Low temperature germanium bolometer, J. Opt Soc. Am. 51, 1300.

Martin, P. E., and H. Richards, Thermistors as cryogenic temperature sensors, Advan. Cryog. Eng. 7, 522.

Mikhailor, N. N., and A. Ya. Kaganorskii, Carbon resistance thermometers for low temperatures, Inst. Exp. Tech. No. 3, 606 (May-June) ; Cryogenics 2, 98 (Dec.).

Nagao, F., S. Ohigashi, and I. Higashino, A radio-frequency resistance thermometer, Jap. Soc. Mech. Engrs. Bull. 4, 340 (May).

Nussbaum, A., Semiconductor thermometers, Control Eng. 8,145 (Sept.).

Orlov, V. Yu., Linearization of the scales of semiconductor thermistor thermometers, Instr. Exp. Tech. No. 1, 198 (Jan.).

Pallett, J. E., The transistor as a temperature-sensing device in temperature control systems, Electron. Eng. 33, 360 (June).

Ramanadham, R., A. V. S. Murty, and M. P. M. Reddy, A thermometer for the study of microthermal structure of the turbulent layer of the ocean, J. Sci. Ind. Res. (India) 20D, 233 (June).

Ryner, H., Temperature measurement in a crystal-oven design, Electron. Design 9, 34 (May 10).

S'chweb, O., and G. C. Temes, Thermistor-resistor temperature sensing networks, Electro-Technol. (New York) 68, 71 (Nov.).

Shaw, D., The transistor as a temperature-sensing device, Electron. Eng. 33, 528 (Aug.)

Ipatov, V. V., and I. Ya. Magin, Miniature resistance thermometers for checking the operation of bearings, Measurement Techniques No. 3, 196 (Mar.).

Tserikh, F. A., Experience gained in using semiconductor resistance thermometers for remote measurements of temperature, Measurement Techniques No. 3, 197 (Mar.).

Yates, B., and C. H. Panter, Indium resistance thermometer, J. Sci. Instr. 38, 196 (May).

Zavaritskil, N. V., and A. I. Shal'nikov, Preparation of miniature carbon resistance thermometers for low temperatures, Instr. Exp. Tech. No. 1, 195 (Jan.).
Altenburger, S., New method for the determination of temperature from the resistance of a standard platinumresistance thermometer, Feingeräte Tech. 11, 116.

Barber, C. R., and J. A. Hall, Progress in platinum resistance thermometry, Brit. J. Appl. Phys. 13, 147 (Apr.).

Barton, L. E., Measuring temperature with diodes and transistors, Electronies 35, 38 (May 4).

Blakemore, J. S., Design of germanium for thermometric applications, Rev. Sci. Instr. 33, 108 (Jan.).

Blakemore, J. S. Germanium for low-temperature resistance thermometry, Instr. Control Systems 35, 94 (May).

Blakemore, J. S., J. W. Schultz, and J. G. Meyers, Measurements on gallium-doped germanium thermometers, Rev. Sci. Instr. 33, 545.

Brown, R. E., W. M. Hubbard, and J. F. Haben, Low temperature thermometers from silicon carbide heating elements, Rev. Sei. Instr. 33, 1282 (Nov.).

Campanella, A. J., A telemetering thermometer, Marine Sci. Instr. 1, 39.

Chambers, J. T., Feasibility investigation and development of $2000^{\circ} \mathrm{C}$ resistance temperature sensor, ASTIA AD-282 358 .

Gadzhiev, S. N., M. Ya. Agarunov, and K. A. Sharifov, Measurement of small temperature differences with thermistors, Zh. Fiz. Khim. 36, 897.

Glick, H. S., Thin film bolometer, Rev. Sci. Instr. 33, 1268 (Nov.).

Godin, M. C., A method of equalizing thermistors, J. Sci. Instr. 39, 241 (May).

Hehenkamp, T., Sensitive pyrometer with high relative reproductivity, Rev. Sci. Instr. 33, 229 (Mar.).

Hunter, J. J., Precision temperature measuring equipment, J. Brit. Inst. Radio Engrs. 24, 251 (Sept.).

MeNamara, A. G., Semiconductor diodes and transistors as electrical thermometers, Rev. Sci. Instr. 33, 330 (Mar.).

Mikhailov, B. I., Thermistor thermometer with a temperature compensating shunt, Instr. Construct. No. 1, 22 (Jan.).

Michaylov, V. A., L. M. Zmusko, and A. G. Lazarev, A device for measuring the temperature and sampling molten metal, ASTIA AD-265 686.

Nordon, P., and N. W. Bainbridge, The use of unmatched thermistor for the measurement of temperature difference under varying ambiant conditions, J. Sci. Instr. 39,399 (July).

Polyakov, Yu. A.. and E. A. Mit-kina, A thin-film resistance thermometer, Instr. Fxp. Tech. No. 4, 764 (July-Ang.).

Sandborn, V. A., Application of the hot-wire, resistancetemperature transducer to the measurement of transient flows, NASA N62-12358.

Sandri, R., R. J. Brisebois, and J. K. S. Wong, On the measurement of the average temperature of a fluid stream in a tube by means of a special type of resistance thermometer, Can., Natl. Res. Council, Div. Mech. Eng., Fuel and Lubricants Lab., Mech. Eng. Rept. MI-826 (Apr.) ; ASTIA AD-283 307.

Schiemer, E. W., A portable temperature indicator, ASTIA $\mathrm{AD}-284328$.

Vanik, M. C., and W. T. Barrett, et al., Reproducible thermistor refinement program, W. R. Grace and Co., ASTIA AD-276 659.

Diode makes accurate cryogenic thermometer, Electronics 35, 28 (Nov. 9).

Gallium arsenide diode proves good low temperature thermometer, Machine Design 34, 26 (Nov. 22).

Silicon temperature sensors, Radio Electron. Components 3, 312 (Apr.).

\section{Radiation Devices}

\section{7}

Popov, V. A., Photopyrometric determination of the temperature of a burning moving particle, 6th Symposium (International) on Combustion, New Haven, Conn., 751, Reinhold Pub. Corp., N.Y. 
Tyroler, T., A self-calibrating high speed photographic pyrometer, 6th Symposium (International) on Combustion, New Haven, Conn., 763, Reinhold Pub. Corp., N.Y.

\section{8}

Gordov, A. N., A. M. Brodskii, M. S. Kaiander, and A. L. Skragan, New equipment for checking heat-power instruments, Measurement Techniques No. 6, 679 (NovDec.).

Gordov, A. N., and E. A. Lapina, A technique of calculating permissible errors in industrial optical pyrometers, Measurement Techniques No. 5, 545 (Sept.-Oct.).

Kandyba, V. V., et al., Apparatus for the determination of flame temperature from the intensity of spectral lines, Trudy Komissii po Pirometrii, Vsesoyuz. Nauch. Issledovatel. Inst. Metrol., Sbornik 1958, No. 1, 69.

Merson, Y. I., Methods and apparatus for measuring flame temperatures from their radiation in the infrared region, Trudy Komissii po Pirometrii, Vsesoyuz. Nauch. Issledovatel. Inst. Metrol., Sbornik 1958, No. 1, 22.

\section{9}

Boyarskii, L. A., et al., Photoelectric method for precise optical pyrometric determination, Proces-Verbaux Séances Comite Inter-Nat. Poids Mesures Ser. 2, 26A, T151.

Burlakov, V. D., Measurement of surface temperature by the brightness-balancing method, Nekotorye Vopr. Eksperim. Fiz. 1959, No. 1, 13.

Greenshields, D. H., Spectrographic temperature measurements in a carbon-arc powered air jet, NASA Tech. Note D-169.

Katys, G. P., Dynamic properties of devices for measuring unstable temperatures, Measurement Techniques No. 3 , 230 (Mar.).

Kirenkov, I. I., and E. A. Lapina, A new method for the determination of the effective wavelength of optical and photoelectric brightness pyrometers, Measurement Techniques No. 4, 288 (Apr.).

Rossler, F., Distribution of temperature of sooty flames, Ann. Phys. 4, 396.

Vollmer, J., G. C. Rein, and J. A. Duke, Light guide radiation pyrometry, J. Opt. Soc. Am. 49, 75.

\section{0}

Ackerman, S., and J. S. Iord, Automatic brightness pyrometer uses a photomultiplier eye, ISA J. 7, 48 (Dec.).

Agnew, W. G., Two-wavelength infrared radiation method measures end-gas temperatures near their peak, $\mathrm{Ab}$ stract: S.A.E. J. 68, 62 (Oct.).

Bell, E. E., P. B. Burnside, and F. P. Dickey, Spectral radiance of some flames and their temperature determination, J. Opt. Soc. Am. 50, 1286 (Dec.).

Boyarskii, L. A., and V. A. Kovalerskii, A laboratory objective spectropyrometer, Measurement Techniques No. $1,38$.

Burrows, M. C., et al., Infrared pyrometer reads engine gas temperature to $\pm 20^{\circ}$ R, S.A.E. J. 68,76 (June).

Butivchenko, I. G., Pyrometer with an automatic signaling of the registration instant, Measurement Techniques No. 11, 957 (Nov.).

Finkelshtein, V. E., and N. G. Starunov, A spectropyrometer for temperature measurements with respect to monochromatic infrared radiation, Instr. Exp. Tech. No. 3, 480 (Dec.).

Finkelshtein, V. E., N. G. Starunov, A standard infrared spectropyrometer, Measurement Techniques No. 1, 35.

Hanel, R. A., The dielectric bolometer, a new type of thermal radiation detector, NASA Tech. Note D-500.

Kirenkov, I. I., Metrological features of color pyrometry, Measurement Techniques No. 1, 33 (Mar.).

Larenz, R. W., Concerning a method for the measurement of very high temperatures in nearly transparent are columns, NASA Tech. Transl. F-54.
Lieneweg, F., and A. Schaller, New technical radiation pyrometer, with special consideration of its optical construction, Appl. Sei. Res. Section B, 241.

Lieneweg, F., and A. Schaller, Recent industrial radiation pyrometers, with special reference to their optical construction, Arch. Tech. Messen, 241 (Nov.) ; 267 (Dec.).

Lovejoy, D. R., Absorbing fllters and high-temperature optical pyrometry, J. Opt. Soc. Am. 50, 698.

Ludwig, H. C., The measurement of temperature in weld. ing ares. Trans. Am. Inst. Elec. Engrs. 79, 191 (July); Elec. Eng. 79, 565.

McDonald, R. K., Gas temperature by infrared, Instr. Control Systems 33, 1926.

MeDonald, R. K., Infrared radiometry, Instr. Control Systems 33, 1527 (Sept.).

Overbye, V. D., et al., Surface temperature variations measured in an operating engine, S.A.E. J. 68, 132 (Oct.).

Parkinson, W. H., and R. W. Nicholls, Spectroscopic temperature measurements in a shock tube using $\mathrm{CN}$ as a thermometric molecule, Can. J. Phys. 38, 715.

Pepperhoff, W., Optical pyrometry in polarized light, Z. Angew. Phys. 12, 168.

Rossler, F., Temperature measurement of a luminous flame, Opt. Acta 7, 20 (Jan.).

Spath, H., and H. Krempl, Temperature measurements in spark discharges made with time resolved spectroscopy, Z. Angew. Phys. 12, 8.

Russell, D. C., and F. H. Schofield, A theory of the filament temperature distribution of the tungsten vacuumlamp, with special reference to optical pyrometry, Phil. Trans. Roy. Soc. (London) A252, 463 (May).

Svet, D. Ya., An automatic photoelectric color pyrometer TsEP-3, Measurement Techniques No. 6, 494 (June).

Svet, D. Ya., New methods for determining the emissivity and reflectivity coefficients and the actual temperature of a self-radiating surface, Soviet Phys.-Doklady 4, 1375 (May-June).

Svet, D. Ya., Radiation pyrometry of metals in the near infrared, Dokl. Akad. Nauk SSSR 130, 61.

Svet, D. Ya., and A. A. Poskachei, some infra-red spectrum pyrometry systems, Instr. Construct. No. 7, 30 (July).

Viasov, M. P., Errors in measuring the temperature of turbulent flames by optical methods, Measurement Techniques No. 11, 50 (Nov.).

Design, construction, and test of an absorption-emission pyrometer, PB 152013 (Dec.).

Measuring temperature: radiation pyrometer, Engineer 210,810 .

Two color pyrometer tells correct temperature, Steel 146 , 144 (Apr. 4).

\section{1}

Agnew, W. G., End gas temperature measurement by a two-wavelength infrared radiation method, S.A.E. Trans. 69, 495 .

Bekefi, G., and S. C. Brown, Microwave measurements of the radiation temperature of plasmas, J. Appl. Phys. 32,25 (Jan.).

Berman, H. L., The infrared radiometric method and its application to remote temperature measurement, Trans. Inst. Radio Engrs. IE-8, 18 (Aug.).

Burrows, M. C., S. Shimigu, P. S. Myers, and O. A. Uyehara, The measurement of unburned gas temperatures in an engine by an infrared radiation pyrometer, S. A. E. Trans. $69,514$.

Chao, B. T., et al., Experimental investigation of temperature distribution at tool-flank surface; using infrared radiation detector, Trans. Am. Soc. Mech. Engrs. B83, 496 (Nov.).

Clouston, J. G., A. G. Gaydon, I. I. Glass, and I. R. Hurle, Temperature measurements of shock waves by spectrum-line reversal method, Proc. Roy. Soc. (I,ondon) A248, 429 (1958); A252, 143 (1959); A262, 39 1961). 
Edwards, D. K., and K. E. Nelson, Maximum error in total emissivity measurements due to non-grayness of samples, ARS J. 31, 1021, (July).

Elder, S. A. Designing phototransistor pyrometers with and without feedback, Electronics 34, 56 (Dec.).

Euler, J., Precision in optical pyrometry, Chem.-Ing.Tech. 33, 448.

Felder, S. A., Designing phototransistor pyrometers, electronics 34, 56 (Dec. 8).

Freeman, L. H., A precision photon counting pyrometer, Los Alamos Sci. Lab., New Mexico, TID-12631.

Gicquel, M., and L. Nadaud, Optical measurement of gas temperatures up to $10,000^{\circ} \mathrm{K}$, Rech. Aeron. No. 84, 31 (Sept.-Oct.).

King, A. R., Compensating radiometer, Brit. J. Appl. Phys. 12, 633.

Kolb, A. C., Measurement of plasma temperatures in the $10,000,000^{\circ} \mathrm{K}$ range, Office of Naval Research, Washington, D.C., ONR-9, 323 .

Kostina, E. N., Temperature compensation in a radiation pyrometer for measuring "low" temperatures, Instr. Construct. No. 6, 3 (June).

Lalos, G. T., and M. Wolk, Feasibility study of the spectroscopic determination and temperature of an adiabatically compressed gas, NAVORD Rept. 6727; ASTIA $\mathrm{AD}-232696$; PB 154720.

Middlehurst, J., and T. P. Jones, Photoelectric optical pyrometer, J. Sci. Instr. 38, 202.

Millikan, R. C., Measurement of particle and gas temperatures in a slightly luminous pre-mixed flame, J. Opt. Soc. Am. 51, 535.

Müller, H., Temperature measurement by measuring radiation, Arch. Tech. Messen, 99 (May).

Nagler, R. G., Application of spectroscopic temperature measuring method to definition of a plasma arc flame, Jet Propulsion Lab. Calif. Inst. Tech. Rept. No. 32-66; ASTIA AD-251 105.

Neuroth, N., Rapid indicating radiation pyrometer for temperature measurement between 300 and $900^{\circ} \mathrm{C}$, Glastech. Ber. 34, 197 (Mar.).

Penner, S. S., Spectroscopic methods of temperature measurements, Calif. Inst. Tech., Pasadena, Guggenheim Jet Propulsion Center, Tech. Rept. AFOSR-286 (Mar.).

Poland, D. E., J. W. Green, and J. L. Margrave, Corrected optical pyrometer readings, Natl. Bur. Std. (U.S.) Monograph 30 (Apr.).

Reynolds, P. M., Emissivity errors of infra-red pyrometers in relation to spectral response, Brit. J. Appl. Phys. 12, 401 (Aug.).

Shiba, K., and K. Doi, Polarization optical pyrometer, Oyo Butsuri 30, 17.

Stall, A. M., The measurement of bioclimatological heat exchange, ASTIA AD-259 074.

Sterling, P. H., and H. Ho, Radiative pyrometry, Ind. Eng. Chem. 53, 53A (Aug.).

Takenaka, Y., Study on radiation pyrometer, J. Japan Sac. Aero. and Space Sci. 9, 1 (Mar.).

Tingwaldt, C., and U. Schley, An optical method for the direct determination of the true temperature of glowing metal, Z. Instrumentenk. 69, 205 (July).

Tsuchiya, S., Temperature measurement by modified $\mathrm{Na}$ D line reversal method, Aeron. Res. Inst. Tokyo Univ. Rept. 366 (June).

Van Laethem, R., et al., Temperature measurement of glass by radiation analysis, Am. Ceram. Soc. J. 44, 321.

Walesch, W., and F. Becker, Continuous temperature control with an optically-regulated control thermometer, Z. Physik. Chem. (Frankfurt) 29, 371.

Wilson, J. H., Temperature measurement with disappearing-filament pyrometer, $\mathrm{R} \& \mathrm{D}$ No. 3,58 (Nov.).

Wurster, W., Spectroscopic measurement of the temperature of shock-heated oxygen, Planetary \& Space Sci. 3, 158 (Feb.).

High-speed three-color pyrometer, Natl. Bur. Std. (U.S.) Tech. News Bull. 45, 148 (Sept.) ; Instr. Control Systems 34,1873 (Oct.).
Photoelectric pyrometer developed, Natl. Bur. Std. (U.S.) Tech. News Bull. 45, 165 (Oct.).

Solar cells improve pyrometer precision, Enginecring 182, 362 .

Symposium on optical spectrometric measurement of high temperatures, Univ. of Chicago, 1960. Optical spectrometric measurements of high temperatures, Univ. of Chicago Press, Chicago.

\section{2}

Allen, R. D., Total emissivity and spectral emissivity at $0.65 \mu$ of porous tungsten and tungsten bearing alloys above $1600^{\circ} \mathrm{K}$, ARS J. 32,965 .

Cooper, J., A fast total response total-radiation detector, Nature (London) 194, 269 (Apr. 21)

Cooper, J., Minimum detectable power of a pyroelectric thermal receiver, Rev. Sci. Instr. 33, 92 (Jan.).

Crabol, J., Solutions to some problems of wall temperature determination, O.N.E.R.A. TR 108 (Nov.).

Donahue, R. J., and R. F. Majkowski, Spectroscopic measurements of temperatures and densities in a cesium plasma, J. Appl. Phys. 33, 3 (Jan.).

Fuhs, A. E., Spectral radiance and emissivity of plasma and temperature determination, ASTIA AD-273 590.

Funk, J. P., Ribbon thermopile, J. Sci. Instr. 39, 32 (Jan.).

Grandin, M., G. Maillot, and P. Rodica, Two-color pyrometer, Mesur. Control Ind. 27, 633 (May).

Hecht, G. J., A near infrared two wavelength pyrometer, Autom. Control 16, 51 (Mar.).

Hottel, H. C., G. C. Williams, P. H. Dundas, and W. P. Jensen, Optical methods of measuring plasma jet temperatures, WADD TR 60-676 (June 1961 and Feb. 1962) ; ASTIA AD-266 723.

Hukuo, N., et al., Measurement of brightness temperature by a photomultiplier, Rept. Gov. Ind. Res. Inst., Nagoya 11, 70 (Feb.).

Kadyshevich, A. E., The present state and lines of development of optical flame pyrometry, Soviet Phys.-Uspekhi 5,346 (Oct.).

Knopp, C. F., C. F. Gottschlich, and A. B. Cambel, A spectroscopic technique for the measurement of temperature in transparent plasmas, AFOSR-1100 ; ASTIA AD-277 352.

Kostkowski, H. J., and R. D. Lee, Theory and methods of optical pyrometry, Natl. Bur. Std. (U.S.) Monograph 41 (Mar. 1).

Lader, S., Spectrographic investigation of temperatures in a plasma jet are tunnel, Picatinny Arsenal Tech. Mem. 1001 (Apr.).

Lapworth, K. C., J. E. G. Townsend, and K. Bridgeman, Reservoir temperature measurements in a hypersonic shock tunnel by sodium line reversal. Part I. Single beam method, Aeron. Res. Council (Gt. Brit.) Rept. No. 23341 (Dec. 1961) ; ASTIA AD-274 711 (July).

Lee, R. D., A new photoelectric pyrometer, Mesur. Control Ind. 27, 647 (May).

Moffit, G., Study of a temperature measuring system for the $1000^{\circ} \mathrm{O}$ to $2500^{\circ} \mathrm{C}$ range, U.S.A.F., Systems Command, Aero Systems Div., Flight Control Lab. ASD TR-61-487 (Feb.) ; ASTIA AD-274 794.

Penzias, G. J., S. A. Dolin, and R. H. Tourin, Infrared rays find rocket gas temperature, Abstract: S.A.E. J. 70, 99 (July).

Peperone, S. J., X-band measurement of shock-tube plasma temperature, J. Appl. Phys. 33, 767 (Feb.).

Schumacher, B. W., W. Wojcik, and R. C. Zavitz, Monitoring system for an oxygen steel furnace using a betaray gauge in the flame, Intern. J. Appl. Radiation Isotopes 13, 123 (Mar.).

Spinrad, H., Spectroscopic temperature and pressure measurements in the Venus atmosphere, Jet Propulsion Lab., Calif. Inst. Tech. JPL-TR-32-251 (June).

Svet, D. Ya., Radiation pyrometry in the blue-violet and ultraviolet regions of the spectrum. Soviet Phys.Doklady 6, 907 (Apr.). 
Themelis, N. J., and W. H. Gauvin, Two-wavelength pyrometer for temperature measurements in gas-solid systems, Can. J. Chem. Eng. 40, 157 (Aug.).

Tourin, R. H., Infrared techniques for temperature measurement in plasmajets, Trans. Am. Soc. Mech. Engrs. 84C, 164 (May).

Tourin, R. H., P. M. Henry, E. T. Liang, M. I. Hecht, and S. Dolin, Measurement of temperatures in ionized gases by means of infrared radiation, Wright-Patterson AFB, Aeron. Res. Lab., ARL 62-314 (Mar.) ; ASTIA $\mathrm{AD}-278045$.

Vali, W., and R. S. De Voto, A two-color pyrometer for the measurement of temperature and contamination level in a spark-heated hypervelocity wind tunnel, Arnold Eng. Develop. Center TDR-62-174 (Aug.) .

Watson, R., Spectroscopic temperature measurements on the $\mathrm{OH}^{2} \Sigma \rightarrow 2 \pi$ band system for a transparent gas in a shock tube, Guggenheim Jet Propulsion Center, Calif. Inst. Tech., Pasadena, Tech. Rept. No. 29 (June).

Photoelectric pyrometer, Instr. Control Systems 35, 178 (July).

Photoelectric pyrometer, Instr. Pract. 16, 77 (Jan.).

\section{Expansion Devices}

\section{9}

Yaryshev, N. A., Inertia response curves for liquid-inglass thermometers, Nauch. Trudy Leningrad, Inst. Tochnoi Mekh. i Optiki 1959, No. 37, 91-8.

\section{0}

Durieux, M., and H. van Dijk, The use of vapor-pressure thermometer in the liquid $\mathrm{He}^{4}$ region, Proc. Intern. Congr. Refrig., 10th, Copenhagen, 1959, 1, 197.

\section{1}

Hall, J. A., and V. M. Leaver, Stabilization of thermometers of borosilicate glass for use at high temperatures, J. Sci. Instr. 38, 178 (May).

Kebbon, E. R., Bimetal thermometers, Instr. Control Systems 34, 841 ( May).

Nelson, R. C., Temperature measurement by filled system, Instr. Control Systems 34, 849 (May).

Oishi, J., High temperature determination by a new gas thermometer with constant bulb temperature. I. Measuring methods, J. Phys. Soc. Japan 16, 2056.

Swindells, J. F., Liquid-in-glass thermometers, Instr. Control Systems 34, 846 (May).

Sychev, I. A., Temperature error of liquid manometric thermometers and methods for compensation, Measurement Techniques No. 10, 803 (Oct.).

Filled-system thermometers, Instr. Control Systems 34, 1250 ( July).

\section{2}

Bendt, P. J., Liquid level He thermometer, Rev. Sci. Instr. 33, 759 .

Gruzsniczki, F., Very precise calibration of glass thermometers, Metrol. Apl. (Bucharest) 9, No. 2, 49.

Schnabel, O., and H. Löber, Physical procedure in the construction of clinical thermometers, Glastech. Ber. 35, 131 (Mar.).

\section{Aspirated Devices}

\section{0}

Goltsov, I. P., Pneumatic thermometer, Priborostroenie 1960, No. $5,13$.

Hochreiter, H. M., Status report on the pneumatic temperature measuring system studies for the EGCR, Oak Ridge Natl. Lab., Tenn., CF-60-12-114 (Dec. 30).

\section{2}

Edmonson, R. B., W. R. Thompson, and A. L. Hines, Theory of a pneumatic dilution calorimetric probe, ARS J. 32, 257.

Welshimer, D. E., The experimental application of sonicpneumatic probe systems to temperature measurement in a hypersonic air stream, U.S. Air Force, Aeron. Res. Lab. ARI-62-364.

Zalmonzon, L. A., High-response measurement of the temperature of gasses and liquids by means of the simplest pneumatic and hydraulic sensing devices, Intern. Chem. Eng. 2, 169 (Apr.).

\section{Other Methods, Descriptive Articles}

\section{8}

Chukaev, K. A., A thermodynamic method of determining mean temperature of flowing gas, Measurement Techniques No. 5, 541 (Sept.-Oct.).

\section{0}

Dean, C., Using nuclear resonance to sense temperature, Electronics 33, 52 (July).

Fasoli, U., F. S. Gaeta, F. Scaramuzzi, and J. O. Thomson, Possibility of an ionic thermometer in the He II temperature range, Proc. Intern. Congr. Refrig., 10th, Copenhagen, 1959, 1, 192.

John, R. S., Field tests of a sonic anemometer-thermometer, Bull. Am. Meteorol. Soc. 41, 618.

Leask, M. J. M., and W. P. Wolf, Magnetic method of temperature measurement between $4^{\circ}$ and $14^{\circ} \mathrm{K}$, Proc. Intern. Congr. Refrig., 10th, Copenhagen, 1959, 1, 179.

McFee, J. H., P. M. Marcus, and I. Estermann, Possible application of molecular beam techniques to the measurement of surface temperature, Rev. Sci. Instr. 31, 1013.

Meyer, R. F., A heat flux meter for use with thin film surface thermometers, Natl. Res. Council (Can.), Natl. Aeron. Estab., NRC LR-279 (Apr.).

Pokhil, P. F., V. M. Maltser, and L. N. Galperin, Apparatus for the determination of temperature from the flame height of burning gun powder, Zh. Fiz. Khim. 34,1131 .

Scott, D. S., Flowmeters for the measurement of gas temperatures, Chem. Eng. Sci. 12, 127.

Siviter, Jr., J. H., and H. K. Strass, An investigation of a photographic technique of measuring high surface temperatures, NASA Tech. Note D-617.

High temperatures inferred from properties of heated gas-stream, Control 4, 120 (Feb.).

\section{1}

Baskin, Y., and D. C. Schell, Rocket nozzles as temperature indicators, ARS J. 31, 1275.

Brodskii, A. D., Electroacoustic gas thermometer for the low temperature range, Measurement Techniques No. 6 , 453 (Dec.)

Byler, W. H., and F. R. Hayes, Fluorescence thermography, Non-destructive Testing 19, 177 (May).

Clark, F. L., and C. B. Johnson, Determination of real-gas stagnation temperature based on mass-flow consideration J. Aerospace Sci. 28, 742 (Sept.).

Hoge, H. J., Temperature measurement based on the viscous flow of gas in a Wheatstone-bridge network, Rev. Sci. Instr. 32, 1 (Jan.).

Louisnard, N., The measurement of surface temperatures by infrared cinemaphotography, Rech. Aeron. No. 80, 29 (Jan.-Feb.).

Miller, J., Temperature-indicating paints and melts, Eng. Mater. and Design 4, 728 (Nov.).

Schultz-Grunow, F., and G. Wortberg, Interferometric measurements in a flat flame, Intern. J. Heat Mass Transfer 2, 56 .

Taylor, R. D., A low temperature thermometer utilizing the Mossbauer effect, Los Alamos Sci. Labs., New Mexico, TID 12627. 
Apfel, J. H., Acoustic thermometry; measuring temperatures by means of the velocity of sound in a gas, Rev. Sci. Instr. 33, 428 (Apr.).

Best, G. T., and T. N. L. Patterson, Temperature determination from a cloud of alkali vapour in the upper atmosphere, Queen's Univ. Belfast (Gt. Britain), AFCRI-62-1049.

Cataland, G., and H. H. Plumb, Acoustical interferometer employed as an instrument for measuring low absolute temperature, J. Acoust. Soc. Am. 34, 1145 (Aug.).

Danberg, J. E., The equilibrium temperature probe, a device for measuring temperatures in hypersonic boundary layers, Naval Ordnance Lab., White Oak, Md., Aeroballistic Research Rept. 146, NOL TR-61-2 (Feb.).

Fletcher, K. A., Precise temperature measurement and control using a.c. bridge techniques, SIMA Rev, 2, 93 (July).

Fournet, M., Kinetic measurement of temperatures, J. Phys. Radium 23, Suppl. No. 3, 25 A.

Gorini, I., and S. Sartori, Quartz thermometer, Rev. Sci. Instr. 33, 883 (Aug.).

Grey, J., and P. F. Jacobs, A calorimetric probe for the measurement of high gas temperature, Guggenheim Labs. for the Aerospace Propulsion Sciences, Princeton, N.J., Aeron. Eng. Lab. Rept. 602 (Apr.) ; AD-275 359.

Grey, J., P. F. Jacobs, and M. P. Sherman, Calorimetric probe for the measurement of extremely high temperatures, Rev. Sci. Instr. 33, 738 (July).

Higgins, L. L., Measurement of temperature, salinity and velocity of water through electrolytic conductivity measurements, ASTIA AD-276 746.

Hisam, E., and W. Bez, Development of a diagnostic device for the determination of mean effective temperatures in plasmas using shock wave measurements, PB 153626 (LC) ; ASTIA AD-235 859.

Long, V. D., Estimation of the mean radiating temperature of a cylinder of combustion gas, J. Inst. Fuel 35, 431 (Oct.).

Schumacher, B. W., W. Wojik, and R. C. Zavitz, Monitoring system of an oxygen steel furnace using a $\beta$-ray gage in the flame, Intern. J. Appl. Radiation Isotopes 13, 123.

Wade, W. H., and L. J. Slutsky, Quartz crystal thermometer, Rev. Sci. Instr. 33, 212 (Feb.).

Walsh, D., The measurement of temperature in an argon shock tube by microwave noise radiation, Aeron. Res. Council (Gt. Brit.) ARC 22930 (June 13).

Low temperature ultrasonic thermometer, Engineering 194, 730 (Nov. 30).

Temperature measurement by change in hardness in metals, Motortech. Z. 23, 49.

\section{Special Applications, Method Not Specified in Title}

1957

Moutet, A., Instantaneous flame-temperature measurements, France, O.N.E.R.A. Tech. Rept. No. 88.

\section{0}

Affeck, J. H., Measuring cathode temperatures, Electronics 33, 80 (Apr. 15).

Becker, F. S., and F. M. Kepler, How to measure tubewall temperature, Oil Gas J. 58, 101 (July 18).

Culpin, M. F., and K. A. Martin, Instruments for measuring the temperature of a running thread-line and of a jet of viscous liquids, J. Sci. Instr. 37, 250 (July).

Daunt, J. G., Thermometers for the temperature range $0.1^{\circ} \mathrm{K}$ to $20^{\circ} \mathrm{K}$, Ohio State Univ. Res. Found. Rept. 712 (Dec.) ; PB 149504.

Dyakonov, I. I., Certain problems in measuring the temperature of rotating objects, Measurement Techniques No. 1, 44 (Nov.).
Eckert, E. R. G., R. Eichhorn, and T. I. Eddy, Measurement of temperature profiles in laminar and turbulent axisymmetric boundary layers on a cylinder with nonuniform wall temperature, USAF, Aeron. Res. Lab., Wright-Patterson AFB, ARL TN 60-61 (Dec.).

Hame, T. G., W. H. Peake, et al., Preliminary analysis of methods for temperature determination at altitudes above 120,000 , Ohio State Univ. Res. Found. Rept. 973-2 (May); PB 152669 (LC) ; ASTIA AD-242 206.

Joseph A. J. V., Fuel nozzle temperature measurement, Engineering 190, 762

Joseph, A. J. V., Temperature measurement of fuel injection nozzles, Hawker Siddeley Tech. J. 2, 2 (Aug.).

Losev, S. A., and N. A. Generalov, Measuring the temperature of a gas downstream from a shock wave, Instr. Exp. Tech. No. 3, 454 (Apr.).

Ryley, D. J., An indirect method of measuring static temperature in supersaturated expanding steam, Engineer 210,343 .

Stewart, L. E., New Ways to measure temperature; $1000 \mathrm{~F}$ and above, Power 104, 218 (May).

Sturgeon, G. M., New wire temperature meter, Wire and Wire Prod. 35, 721 (June).

Sturgeon, G. M., Wire temperature measurement, Wire Inds. 27, 261 (Mar.).

Svinoruk, V. I., and L. F. Lependin, Temperature measurement at a point on the surface of an electrically conductive sample, Ind. Lab. 26, 785 .

Thun, R. E., Rugged film resistor thermometer for the measurement of surface temperature, Rer. Sci. Instr. 31, 446 (Apr.)

Wood, R. D., Heated hypersonic stagnation-temperature probe, J. Aerospace Sci. 27, 556 (July).

Flame temperature determination, Instr. Control Systems 33, 821 (May).

Precision thermometry at low temperature, Electronics 33, 98 (June).

Thermometer for $600 \mathrm{deg}$. C plus. Space/Aeronautics 33, 242 (May).

Thermometry for Iow temperature, Instr. Control Systems $33,1917$.

Wire temperature meter, Metallurgia 62, 64 (Aug.).

\section{1}

Beattie, J. R., The measurement of the temperature of transparent materials, Acta Imeko, 210.

Blackshear, P. L., Probe senses fast temperature changes, Chem. Eng. News 39, 39 (Aug. 28).

Blackshear, P. L., and L. M. Fingerson, Some new measuring techniques in high temperature measurements James Forrestal Res. Center, Princeton Unir., N.J., Tech. Rept. MIN-3-P (Dec.) ; ASTIA AD-270 364.

Brodskii, A. D., and A. T. Sarataer, A new method of absolute temperature measurement, Measurement Techniques No. 5, 397 ( Jan.).

Brown, E. A., et al., Steady-state heat flux gauge, Rev. Sci. Instr. 32, 984 (Aug.).

Daunt, J. G., and D. O. Edwards, Measurement of temperature below 1 degree $\mathrm{K}$, ASTIA AD-255 582 .

De Leo, R. V., F. D. Werner, and F. W. Hagen, Measurement of mean temperature in a duct, Instr. Control Systems 34, 1659 (Sept.).

Elliott, R. D., Dynamic beharior of missile skin temperature transducers, Proc. Instr. Soc. Am. 16, Paper No. 160-LA-61.

Gordor, A. N., et al., Complex of metrological work on establishing methods and apparatus for precise measurements of high temperature, Measurement Techniques No. 1, 31 (Jan.).

Kazachkor, R. V., Measurements of the piston temperature of high-speed internal combustion engines, Measurement Techniques No. 5, 402 (Jan.).

Lemke, B., Determination of final temperature in a gun tunnel, J. Aerospace Sci. 28, 827 (Oct.).

Moore, F. D., and R. B. Mesler, Measurement of rapid surface temperature fluctuations during nuclea te boiling of water, A.I.Ch.E. J. 7, 620 (Dec.). 
Netter, P., G. Seyffarth, and H. John, Design and function of a submerged temperature measuring device in an open hearth steelworks, Neue Hütte 6, 475 (A ug.).

Ney, E. P., R. W. Maas, and W. F. Huch, The measurement of atmospheric temperature, J. Meteorol. 18, 60 (Feb.)

Overbeck, C. J., Apparatus review; demonstration thermometer, Am. J. Phys. 29, 368 (June).

Rae, D., A measurement of the temperature of some frictional sparks, Combust. Flame 5, 341.

Reimer, L., and R. Christenhuss, a reversible temperature indicator in the form of an evaporated layer for estimating the temperature of an object in the electron microscope, Naturwissenschaften 48,619 .

Schoolman, S. A., and D. A. McBlain, The measurement of temperature changes in an adiabatic expansion, Proc. Iowa Acad. Sci. 68, 439.

Stewart, L. E., Measure gas temperature by multipoint traversing, Power 105, 180 (Feb.).

Walker, R. E., and S. E. Grenleski, Instrument for measuring total incident radiant heat transfer to a jet engine surface, ARS J. 31, 77 (Jan.).

Werner, F. D., R. V. De Leo, and B. Rogal, Total temperature probes, Flight 80, 737 .

Measurement of engine temperature, Engineer 211, 386.

Pyrometer for moving surfaces, Control 4, 120 (Feb.).

Temperature measurement of moving engine components Shell Aviation News No. 281, 8.

\section{2}

Baldwin, A. L., Dynamic temperature coefficient measurements, Instr. Control Systems 35, 97 (May).

Cooper, J., A fast-response pyroelectric thermal detector, J. Sci. Instr. 39, 467 (Sept.).

Ebel, H., A method of measuring rapidly changing temperatures, Naturwissenschaften 49,80 .

Eschenbach, R. C., Water temperature measurement, Am. J. Phys. 30, 604 (Aug.).

Fletcher, K. A., Industrial temperature measurement, Ind. Electron. 1, 66 (Nov.).

Hadfield, D., Periodic pyrometer checks accelerate steel process, Steel 150, 92 (Feb.).

Land, T., Advances in glass temperature measurement, Glass Ind. 43, 244 (May).

Magnus, A. B., Calculating temperatures in hydraulic systems, Hydraulies and Pneumatics 15, 69 (Nov.).

Manson, D. J., Temperature measurements in oxy-hydrogen flames using scattered neutrons and conventional methods, ASTIA AD-277 747.

Muntz, E. P., Static temperature measurements in a flowing gas, Phys. Fluids 5, 80 .

Rosenberg, N. W., W. H. Hamilton, and D. J. Lovell, Rocket exhaust radiation measurements in the upper atmosphere, Appl. Optics 1, 115 (Mar.).

Swain, R. R., Pyrometer monitors molten metal temperatures, Steel 150, 78 (June 4).

Vidal, R. J., Transient surface temperature measurements, Cornell Aeron. Lab. Rept. 114 (Mar.); ASTIA AD-275 818.

Woodley, J. G., and J. F. W. Crane, A boundary layer probe for the direct measurement of aerodynamic heating, Royal Aircraft Establ. (Gt. Brit.), Tech. Note No. Aero 2808 (Jan.) ; ASTIA AD-274 842 (July).

Maximum temperature indicators, $R \& D, 48$ (Jan.).

Measuring traction motor commutator temperature, Engineer 214, 30 ( July 6 ).

Miniature thermometer for moving parts, Engineering 194,800 .

Probe for measurements in high-temperature fluids, Control 5, 96 (July).

Surface pyrometer for high-speed cylinders, Engineer 214, 960 (Nov. 30).

Temperature measurement of metallic surfaces, Eng. Mater. and Design 5, 116 (Feb.).

\section{Nuclear Applications of Temperature Measurement}

1960

Clark, R. G., Clamp-on resistance temperature detectors for reactor use, Metal Progr. 78, 156 (Aug.).

Gilbert, R. L. G., Analogue-digital converter with long life, equipment designed for temperature measurement in nuclear power stations, J. Brit. Inst. Radio Engrs. 20,529 (July).

Guskov, Yu. K., and A. V. Zvonarev, Thermocouple system for measurement of large neutron fluxes, Instr. Exp. Tech. No. 5, 821 (June).

Harmon, T. P., An electroplated neutron thermopile for the 3-Mw GTR, NARF-59-20T; MR-N-226; PB 150016 (LC).

Kosut, B. S., Specifications for thermocouples, stainless steel sheathed, corrosion resistant for nuclear service, General Electric Co., Hanford At. Prod. Operation, Richland, Wash., HW-64744 (Apr.).

Lovett, D. B., Use of isolated junction sheathed thermocouples for moderator temperature measurements, General Electric Co., Hanford At. Prod. Operation, Richland, Wash., HW-65738 (June 16).

\section{1}

Clough, D. J., Temperature control and measurement in sodium-filled irradiation capsules, AERE R-3689 (Apr.).

Ross, C. W., Effect of thermal neutron irradiation on thermocouples and resistance thermometers, Trans. Inst. Radio Engrs. NS-8, 110 (Oct.).

Shenault, L. H., and T. F. McGrath, Reactor core temperature measurement, ARS J. 31, 799 (June).

Development of high temperature sensors, U.S. At. Energy Comm. PWAC-339 (June 30).

Driesner, A. R., L. P. Kempter, C. P. Landahl, C. A. Linder, and T. E. Springer, High temperature thermocouples in the Rover Program, Trans. Inst. Radio Engrs. NS-9, 247 (Jan.)

McCann, J. A., Temperature measurement theory, At. Energy Comm. Rept. KAPL 2067-2 (Apr. 1).

Ross, C. W., Effect of thermal neutron irradiation on thermocouples and resistance thermometers, Commun. Electron., 192 ( July).

\section{Associated Equipment and Testing Procedure}

1951

Tarr, P. R., Methods for connection to revolving thermocouples, NACA Res. Mem. E50J23a (Jan. 18).

\section{8}

Lalos, G. T., R. J. Corruccini, and H. P. Broida, Design and construction of a black body and its use in the calibration of a grating spectroradiometer, Rev. Sci. Instr. 29, 505 .

Levin, G. M., and V. I. Volmir, Characteristic thermal inertia curves of conventional thermocouples and resistance thermometers, Measurement Techniques No. 6, 686 (Nov-Dec.).

Nikiforov, V. D., Testing thermocouples and pyrometric instruments, Measurement Techniques No. 5, 548 ( Sept.Oct.).

\section{9}

Arefer, A. A., Three-channel amplifier equipment for thermocouples, Measurement Techniques No. 2, 120 (Feb.).

\section{0}

Almond, R. J., Errors in thermocouple circuits, Instr. Control Systems 33, 80 (Jan.).

Ashekhmin, V. I., and E. V. Kovalskii, A slide rule for thermocouples, Measurement Techniques No. 2, 115 (Nov.). 
Briscoe, W. L., Improved bridge for low temperature measurements, Rev. Sci. Instr. 31, 999 (Sept.).

Dauphinee, I. T. M., and H. Preston-Thomas, Direct reading resistance thermometer bridge, Rev. Sci. Instr. 31, 253.

Eisner, R. L., Apparatus for accurate measurement of thermoelectric power, Rev. Sci. Instr. 31, 462 (Apr.).

Foltz, H. L., and W. R. Brown, Self-sealing thermocouple gland, Machine Design 32, 176 (May 12).

Harman, G. G., Hard gallium alloys for use as low contact resistance electrodes and for bonding thermocouples into samples, Rev. Sci. Instr. 31, 717 (July).

Holden, T. S., Multipoint digital temperature recorder with punched tape output, J. Sci. Instr. 37, 269 (Aug.).

Kane, M. V., Thermocouple current indicators, Instr. Control Systems 33, 608 (Apr.).

Kurtzrock, R. C., Quick connector for multipoint thermocouple assemblies, Rev. Sci. Instr. 31, 457 (Apr.).

Levin, G. M., and V. I. Volmir, Methods for testing thermal inertia in thermocouples and resistance thermometers, Measurement Techniques No. 4, 309.

Moeller, C. E., Do shields improve thermocouple response? ISA J. 7, 56 (Aug.).

Premak, W., and E. Edwards, Large recording potentiometer errors caused by furnace leakage currents, Rev. Sci. Instr. 31, 1242 (Nov.).

Ross, G. S., and H. D. Dixon, Automatic precise recording of temperature, J. Res. Natl. Bur. Std. (U.S.) 64C, 271.

Sirota, A. M., et al., Methods of testing thermocouples and thermocouple wires, Ind. Lab. 26, 126 (Jan.).

Multipoint temperature scanner, Engineer 209, 693.

USN develops new thermowell for high-velocity steam, ISA J. 7, 34 (Nov.).

\section{1}

Accinno, D. J., A vacuum furnace for high temperature thermocouple calibration, Engelhard Ind., Tech. Bull. 2, 16 (June)

Andreev, S. V., B. K. Martens, and A. N. Trushinskii, Transistorized instrument for remote measurement and control of temperature, Measurement Techniques No. 11, 882 (Nov.).

Antier, G., A thermostatic enclosure for thermocouples, Mesur. Control Ind. No. 294, 1335 (Nov.).

Avdeev, A. I., D. A. Ilmenskii, and M. D. Notarius, Application of asymmetrical bridge in electromagnetic measuring instruments for resistance thermometers, Instr. Construct. No. 6,1 (June).

Beerman, H. P., High temperature black body radiation source, Bull. Am. Ceram. Soc. 40, 308 (May).

Bratkowski, W., Fast-response temperature controls, Prod. Eng. 32, 40 (May 29).

Freeman, R. J., Thermoelectric stability tests, General Electric Co., Nuclear Mater. and Propulsion Operation, Cincinnati, U.S. At. Energy Comm. APEX-746 (Aug.).

Godin, M. C., Simple bridge for the direct measurement of temperature differences, J. Scl. Instr. 38, 330 (Aug.).

Green, B. A., Simple ac resistance bridge using a dc breaker amplifier, Rev. Sci. Instr. 32, 364.

Kayander, M. S., Differential instrument for comparing radiation pyrometers, Measurement Techniques No. 2, 119 (Feb.).

Middlehurst, J., Mercury switch for establishing the true electrical zero in precise thermocouple measurements, J. Sci. Instr. 38, 165 (Apr.).

Moodie, W. C., Thermal switches and transducers for discreet and continuous temperature control, Space Aeronautics 36, 127 (July).

Nalle, D. H., Accurate recordings of fast-changing temperatures, ISA J. 8, 58 (June).

Pak, V., Computation of the basic parameters for a telescope of a radiation pyrometer with a thermistor, Measurement Techniques No. 12, 879 (Dec.).

Seshadri, T. N., and S. P. Jain, A constant ice point Junction for thermocouples in continuous use for long periods, J. Sci. Ind. Res. (India) 20D, 161 (Apr.).
Simmons, F. S., A. G. De Bell, and Q. S. Anderson, A $2000^{\circ} \mathrm{C}$ slit-aperture blackbody source, Rev. Sci. Instr. 32,1265 (Nov.).

Sutcliffe, J., Direct-reading resistance-thermometer bridge, Instr. Control Systems 34, 293 (Feb.).

Testardi, L. R., and G. K. McConnel, Measurement of the Seebeck coefficient with small temperature differences, Rev. Sci. Instr. 32, 1067 (Sept.).

\section{2}

Ballard, G. G., Transistor thermocouple trip amplifier, J. Brit. Inst. Radio Engrs. 23, 35 (Jan.).

Bansal, T. D., Calibration equipment for surface pyrometers and pipe thermometers, J. Sci. Instr. 39, 232 (May).

Belling, P. R., High-pressure thermocouple feed-through, Instr. Control Systems 35, 119 (Nov.).

Benedict, B. V., Vibration test of thermocouple type 300RD $\mathrm{P} / \mathrm{N} 8968365$, ASTIA AD-275 686.

Bose, B. N., Thermocouple well design, ISA J. 9, 89 (Sept.).

Boudreaux, P. J., Providing thermocouple compensation at low cost, Electronics 35, 72 (Nov.).

Bridle, J. A., and J. L. Morgan, High-speed temperature recording, J. Iron Steel Inst. (London) 200, 318 (Apr.).

Brownwood, J. B., Thermocouple compensating circuit design, Electronics 35, 98 (Jan. 5).

Cameron, G., and R. L. Blanchard, Design and operation of a pressure-type cryostat for thermometer calibration in the liquid-hydrogen region, ISA Trans. 1. 255 (July).

Greenwood, T. L., Indicator warns of excessive rise rates, Electronics 35, 54 (Feb.).

Katadeladze, K. S., E. N. Zedginidze, and T. V. Nozadze, Thermocouple immersion tips for measuring the temperature of molten metals, Ogneupory 27, 223.

Katateladze, K. S., E. N. Zedginidze, and P. A. Pirumova, Thermocouple protection tubes made of carborundum with a nitride binder, Stal 22, 237.

Kocho, V. S., A. D. Panasyuk, G. V. Samsonov, A. G. Strelchenko, and I. G. Khavrunyak, Zirconium boride cermet protection tubes for thermocouples, Stal 22, 317.

Lash, J. B., Inexpensive testing for precision sensors, Instrumentation $15,4$.

MacDonald, W. R., Simple amplifier for use with metalfllm thermometers in timing applications, J. Sci. Instr. $39,35$.

Mandt, R. D., Fusing thermocouple leads, ISA J. 9, 82 (Nov.).

McAllan, J. V., Selector switch to avoid transient selfheating in resistance thermometers, J. Sci. Instr. 39, 447.

Manigan, J., and E. J. Nichols, Thermocouple sensing tip, Mater. in Design Eng. 55, 147 (Apr.).

Pitts, E., and P. T. Priestly, Constant sensitivity bridge for thermistor thermometers, J. Sci. Instr. 39, 75 (Feb.).

Priem, M., Method for sealing thermocouple wire through fused silica for use at high temperature, J. Sci. Instr. 39, 130 (Mar.).

Ramage, R. V., Ultra-high pressure seals for instrumentation leads, Design Eng. 55, 156 (May).

Rautio, W. S., Metal-sheathed ceramic-insulated thermocouples; swage or draw?, Instr. Control Systems 35, 101 (May).

Samsonov, G. V., P. S. Kislyi, and A. D. Panasyuk, Zirconium boride tips for immersion thermocouples, ASTIA AD-283 891.

Sondericker, J., Zener diodes replace thermacouple icejunction, Electron. Design 10,42 (Feb. 1).

Thomas, D. B., A furnace for thermocouple calibrations to $2200^{\circ} \mathrm{C}$, J. Res. Natl. Bur. Std. (U.S.) $66 \mathrm{C}, 255$.

Turco, J. F., J. Hickey, and I. Bar-Gadda, Sample holder for use in the measurement of thermoelectric power of thermoelectric materials, Rev. Sci. Instr, 33, 384 (MIar.).

Whiteway, S. G., Sintering long thermocouple sheaths without warping, Am. Ceram. Soc. Bull. 41, 95 (Feb. 15). 
Wright, H. C., A thermocouple slide-rule, J. Sci. Instr. 39, 238 (May).

An improved resistance thermometer bridge, Instr. Pract. 16, 191 (Feb.).

Improved resistance-thermometer bridge, Electro-Technol. (New York) 70, 146 (Oct.).

Sealing thermocouples in pressure vessels, Engineering $193,4$.

Time temperature integration device, General Electric Co., ASTIA AD-271 416.

\section{General 1958}

Frost, F. E., High temperature production and measurement-a bibliography, Lawrence Radiation Lab., Univ. Calif., Livermore, Calif., U CRL-5409.

\section{9}

Allegre, R., et al., Etudes de Pyrometrie pratique, Editions Eyrolles, Paris.

Bayley, H. G., Recent developments in the precise measurement of temperature, J. Inst. Engrs. Australia 31, 227 (Sept.).

Hurwitz, H., Review of methods for measuring temperatures up to $20,000^{\circ} \mathrm{K}$, Naval Ordnance Lab., White Oak, Md., NAVORD-6680 (July 6) ; ASTIA AD-232 698; PB 154722 (LC).

Lier, R. H., High temperature measuring techniques 1948 to present (bibliography), U.S. Sci. Lab. Los Alamos, LAMS-2325.

McCoy, E., Bibliography on gas temperature measurement, United Kingdom At. Energy Authority, I. G. information series $68(\mathrm{RD} / \mathrm{CA})$.

Strelkov, P. G., and D. I. Sharevskaya, Results of comparing temperatures calculated by the $\mathrm{M}$ SH $\mathbf{T}$ and the comparison method, Measurement Techniques No. 2, 124 (Feb.).

Theoretical and experimental research in thermoelectricity (Dec.), PB 161468.

1960

Angello, S. J., Recent progress in thermoelectricity, Elec. Eng. 79, 353 (May).

Beltran, A. A., A preliminary literature survey. High temperature strain and temperature sensing devices, Lockheed Aircraft Corp., Missiles and Space Division, Special bibliography SB-60-3.

Combes, J. J., Temperature measuring devices, Automation 7, 87 (May)

Coxon, W. F., Temperature measurement and control, Macmillan, N.Y.; Heywood and Co., London.

Grimes, W. R., and D. R. Cuneo, eds., High temperature thermometry seminar, held Oct. 1-2, 1959 at Oak Ridge Natl. Lab., U.S. At. Energy Comm. TID-7586 (pt. 1) (Aug.).

Hedge, J. C., et al., Temperature measuring techniques, Wright Air Develop. Div., Wright-Patterson AFB, WADD-TR-60-487 (June) ; ASTIA AD-253 483.

Jackson, E. W., Temperature measurement and control, Chem. Process Eng. 41, 139 (Apr.).

Kebbons, E. R., Miscellaneous temperature-measuring methods, Instr. Control Systems 33, 1921 (Nov.).

Kostkowski, H. J., The accuracy and precision of measuring temperatures above $1000^{\circ} \mathrm{K}$, International Symposium on high temperature technology, Asilomar conference grounds, Calif., Oct. 5-9, 1959, McGraw-Hill Book Co., N.Y., 1960, p. 33.

Meyer-Wittig, o., Calculation for determining the response lag of temperature probes under periodic changes of temperature, Electrotech. 38, 501 (Sept. 29).

Plumb, H. H., Secondary thermometry grows more precise, Chem. Eng. News 38, 40 (Oct. 31).

Stewart, L., How to handle the problem of measuring low temperature, Power 104, 208 (Nov.).
Werner, F. D., Total-temperature measurements, Instr. Control Systems 33, 800 (Maj).

Thermoelectricity abstracts (Mar.), PB 161301 (OTS).

Thermoelectricity abstracts, PB 161174 (Dec.).

Thermoelectricity, OTS selective bibliography SB-432 (Sept.).

Thermopiles and thermocouples, OTS selective bibliography SB-430 (Aug.).

\section{1}

Awano, M., Precisionization of gas thermometry, J. Phys. Soc. Japan 16, 2560.

Baker, H. D., E. A., Ryder, and N. H. Baker, Temperature measurement in engineering, Vol. II, John Wiley \& Sons, Inc., N.Y.

Brinich, P. F., Recovery temperature, transition and heattransfer measurements at Mach 5, NASA Tech. Note D-1047.

Danlouz-Dumensnils, M., From the Florentine thermometer to that of Lyons, Mesur. Control Ind. 26, 1023 (Sept.).

Kallen, H. P., Handbook of instrumentation and controls, MeGraw-Hill Book Co., N.Y.

Kennedy, J. H., et al., High temperature measurement and production-a bibliography, Lawrence Radiation Lab., Univ. Calif., Livermore, Calif., UCRL-6424.

Pivovonsky, M., and M. Nagel, Tables of blackbody radiation functions, Macmillan Co., N.Y.

Snyder, P. E., Chemistry of thermoelectric materials, Chem. Eng. News 39, 102 (Mar. 13).

Sterrett, S. J., Improved manufacturing techniques for blood-flow probes, J. Sci. Instr. 38, 59 (Feb.).

Upton, Jr., E. F., Measuring industry's hot spots, Plant Eng. 15, 117 (Oct.) ; 109 (Nov.).

Yaryshev, N. A., Inertial parameters of resistance thermometers and thermocouples, Measurement Techniques No. 9, 716 (Sept.).

Yeaple, F., a new look at temperature-measuring transducers, Prod. Eng. 32, 49 (May 22).

The platinum metals in temperature measurement, Platinum Metals Rev. 5, 89 (July).

\section{2}

Ball, I. D. L., Temperature-measurement techniques discussed, R\&D No. 13, 30 (Sept.).

Coombe, R. A., Measuring temperature and Mach number in a high temperature gas flow, R\&D No. 15, 38 (Nov.).

Hertzfeld, C., ed. in chief, Temperatures, its measurement and control in science and industry. Volume 3 , part 1 , Basic concepts, standards and methods, F. G. Brickwedde, ed.; Volume 3, part 2, Applied methods and instruments, A. E. Dahl, ed., Rheinhold Pub. Corp., N.Y.

Holland, M. G., L. G. Rubin, and J. Welts, Temperature measurement from $2^{\circ} \mathrm{K}$ to $400^{\circ} \mathrm{K}$, Instr. Control Systems 35, 89 (May).

Holzbock, W. G., Instruments for measurement and control, 2nd ed., Reinhold Pub. Corp., N.Y.

Hunter, J. J., Precision temperature measuring equipment, J. Brit. Inst. Radio Engrs, 24, 251 (Sept.).

Huovila, S., Contributions to the measurement and interpretation of small-scale temperature fluctuations, Academic Bookstore, Helsenki, Finland.

Katz, A. J., Thermal testing, Space-Aeronautics 38, 30 (Oct.).

Lathrop, P., Technique for temperature measurement, Ind. Phot. 11, 12 (Mar.).

Liddiard, F. E., and J. H. Heath, Temperature measurement, Control, part $1,5,95$ (Sept.) ; part 2, 5, 109 (Oct.) ; part 3, 5, 110 (Nov.).

Lieneweg, F., Temperature measurement, Arch. Tech. Messen No. 313, 47 (Feb.).

White, F. J., Accuracy of thermocouples in radiant-heat testing, Exp. Mech. 2, 204 (July).

Yarishev, N. A., and A. S. Makhnovetskiy, Errors in the measurement of transient surface temperatures, ASTIA AD-265 800. 


\section{Bibliography of Temperature Measurement January 1963 to December 1965 Lief 0. Olsen and Carl Halpern}





\title{
BI BL IOGRAPHY Of TEMPERA TURE MEASUREMENT
}

January 1963 to December 1965

\author{
Lief 0. Olsen and Carl Halpern
}

There are presented in this supplement to NBS Monograph 27, "Bibliography of Temperature Measurement, January 1953 to June 1960" issued April 6, 1961 and Supplement 1, July 1960 to December 1962 issued September 13, 1963, about 1200 additional references to the field of temperature measurement. The period covered is from January 1963 to December 1965 with some earlier references which came to our attention. With the exception of Part 1 which has been changed to include theory; calibration and temperature scales, the arrangement of material is the same as in Monograph 27. The journal abbreviations used are those employed in Chemica! Abstracts.

Key words: Temperature, thermometry, thermocouples, thermistors, resistance thermometer, and radiation pyrometry

\section{NTRODUCTION}

The material contained herein was collected from two general sources: scientific and technical journals and reports of investigations sponsored or conducted by various governmental agencies. English, German, and French journals and translations in English of Russian journals were covered as well as the more commonly used abstract journals. Some references to material in other languages, obtained from the abstract journals, are also included. To obtain references to governmental reports the following were consulted: Technical abstract Bulletin, Armed Services Technical Information Agency; Scientific and Technical Aerospace Reports, National Aeronautics and Space Administration (NASA); Nuclear Science Abstracts, United States Atomic Energy Commission; and U.S. Government Research Reports, Office of Technical Information, U.S. Department of Commerce. While reasonably complete coverage was intended, it is inevitable that oversights and other unintentional omissions have occurred.

The topical subdivisions are shown in the table of contents. Each subdivision is arranged chronologically and within the chronological sections, alphabetically by author. "Anonymous" articles appear at the end of each section.

The period covered is from January 1963 to December 1965 with some ear lier entries which had been overlooked in the original bibliography NBS Monograph 27 and its $f$ irst supplement .

The journal abbreviations used are those employed in Chemical Abstracts. Volume numbers are underlined and date of issue is given where page numbers do not run consecutively throughout a given volume. Since the year of issue apears at the head of each chronological section, this is not repeated in the individual references.

Numbers prefixed by the letters AD refer to report numbers ill the Technical Abstract Bulletin; those by N63, N64, and N65 are identifying numbers in the Scientific and Technical Aerospace Reports; and those by NSA refer to the report numbers in Nuclear Science Abstracts. 
1. Theory, Calibration and Temperature scales

1958

Lowenthal, G.C., W.R.G. Kemp and A.F.A. Harper, Temperature scale down to $20^{\circ} \mathrm{K}$ using platinum resistance thermometers, Low Temp. Phys. Thermodyn., Proc. Meeting Comm. I Intern. Inst. Refrig., Delft, Neth., 107.

1960

Aryhanov, A. S., A. N. Gordov, and U. V. Diikov, A new determination of the melting point of gold, Tr. Vses. Nauchn. Issled. Inst. Metrol., 49, 5.

\section{1}

Hudson, R. P., Low temperature thermometry, ExptI. Cryophys. 1961, 213.

Sherman, R. H., T. R. Roberts, and S. E. Sydoriak, Helium- 3 vapour pressures: a standard for improved thermometry below $1^{\circ} \mathrm{K}$, Bull. Inst. Intern. Froid, Annexe $5,1961,125$.

\section{2}

Barber, C.R., Boiling points of hydrogen, Comite Consultatif Thermometrie, Comite Intern. Poids Mesures, 6e, Sevres, France, 1962, 97.

Bragin, B. K., Solidification point of copper, Measurement Techniques No. 3, 214 (Sept.).

Brodsky, A. D., V. P. Kemlevsky, and A.V. Savateev, New methods of realizing the thermodynamic scale in the low temperature region, Comite Consultatif Thermometrie, Comite Intern. Poids, Mesures, 6e, Sevres, France, 1962, 171.

Jaumot, F.E., Thermoelectricity, Advanced Electron. and Electron Phys. 17, 207.

Kirenkov, I.1., et al, New measurements of the thermodynamic temperatures of the reference points of tin, cadmium zinc and gold, Izmeriteln. Tekhn. No. $9,31$.

Kirenkov, 1. 1., Investigation of thermodynamic temperature reference points, Measurement Techniques No. 4, 286 (Sept.).

Pak, V., Calibration of thermocouples in a dynamic condition, Measurement Techniques No. 6,475 (Dec.).

Sherman, R. H., T62 Hel ium- 3 temperature scale IV. Tables, U.S. At. Energy Comm. LAMS - 2701 .

\section{3}

Benedict, R.P., The generation of thermocouple reference tables, Electro-Technology (N.Y.) 72, 80 (Nov.).

Benedict, R. P., and H. F. Ashby, Emperical determination of thermocouple characteristics, Trans. ASME (J.Eng. Power) 85A, 9 .
Benedict, R.P., and J.W. Murdock, Steadystate thermal analys is of a thermometer well, Trans. ASME (J.Eng. Power) 85A, 235.

Bonanno, A. M., Commercial laboratory temperature calibrating services with reference traceable to the National Bureau of Standards, Proc. Instr. Soc. Am. 18 Paper No. 57-2-63.

Bragin, B.K., Calibration of standard thermocouples at the freezing point of copper, Tr. Inst. Kom. Standartov, Mer i Izmerit. Priborov pri Sov. Min. SSSR $1963,97$.

Brickwedde, F. G., International practical temperature scale, Phys. Today 16, 24 (May).

Brindley, J. H., Calibration of surfaceattached thermocouples on a flat-plate fuel element by electrical analogue and analytical techniques, Trans. Am. Nucl. Soc. 6, 333 (Nov.).

Brodski $\bar{i}, A . D ., V . P . K r e m l e v s k i i$, and $A$. $\checkmark$. Savateev, New methods of producing the thermodynamic scale at low temperatures, Measurement Techniques, No. 9, 757 (Apr.).

Grambur $g_{1}, G_{.}$, and H. G. Flust, Developments in the field of thermoelectricity, Naval Engrs. J. 75, 925 .

Hall, J.A., Role of the platinum-resistance thermometer in the International Practical Scale of Temperature, Proc. Inst. Elect. Engrs. 110, 1502 (Aug.).

Kamochkina, E. M., and N. N. Ergardt, Constant solidification point of palladium,

Tr. Inst. Kom. Standartov, Mer i Izmerit. Priborov pri Sov. Min. SSSR No. 71, 237.

Kirenkov, 1.1., New evaluation of the thermodynamic temperatures of the tin, cadmium, zinc and gold reference points, Measurement Techniques No. 9, 752 (April).

Kirenkov, 1. 1., The thermodynamic and the international practical temperature scales, Z. Instrumentenk. 71, 43 (Feb.).

Kocherzhinski $i, Y u$. $\bar{A}$. , et al, Calibration of the VR - 5/20 thermocouple by critical points up to $3000^{\circ}$, Sb Nauchn. Tr. Inst. Metallfiz., Akad. Nauk Ukr. SSR No. $17,200$.

Lovejoy, D. R., Some boiling and triple points below $0^{\circ} \mathrm{C}$, Nature 197, 353 (Jan. 26).

Lucke, W. H., A brief survey of elementary thermoelectric theory, NRL Rept. 5880 (May), AD-405854; N 64-20326.

McLaren, E. H., and E. G. Murdock, The Freezing points of high purity metals as precision temperature standards. VII Thermal analysis on seven samples of bismuth with purities greater than $99.999 \%$, Can. J. Phys. 41, 95 (Jan.).

Null, M. R., and $\bar{W}$. W. Lozier, Carbon-arc radiation standard, Instr. Control Systems 36, 93 (May).

Rebiene, J., R. Beranger, and P. Perroud, Calibration of thermocouples for low temperatures, Comm. Energie At. (France) Note No. 418.

Rechter, M., Use of high purity materials in thermometry, Reinststoffe wiss. Tech., Intern. Symp., 1, Dresden 1961, 345. 
Swindells, J.F., Calibration of temperature measuring instruments at the Natl. Bur. of Std., Misc. Publ. U. S. Bur. Stand. 240 (Aug. 16).

sydoriak, S. G., T. R. Roberts, and R. H. Sherman, The $\mathrm{T}_{62}$ "Helium- 3 temperature scale, Proc. Intern. Conf. Low temp. Phys., 8th. London 1962, 437; Low Temperature Physics, Butterworth's Washington, D.C. (1963), 437 .

Van Dijk, H., Units of temperature and temperature scale, Z. Angew. Phys. 15, 561 (June).

Calibration of temperature measuring instruments at the Natl. Bur. of Std., Engineer 215, 501 .

Temperature calibrations, Instr. Pract. 17, 190 (Feb.).

The international Committee on Weights and Measures, Nature 197, 1055 (Mar. 16).

\section{4}

Astrov, D.N., M.P. Or lova, and D. I. Sharevskaya, Extension of the practical international scale of temperature below $-182.97^{\circ}\left(90.18^{\circ} \mathrm{K}\right)$, Comite Consultatif Thermometrie, Comite Intern. Poids Mesures, 6e, Sevres, France 1962, 102.

Bedford, R.E., Reference tables for platinum 20\% rhodium/platinum $5 \%$ rhodium thermocouples, Rev. Sci. Instr. 35 , 1177 (Sept.).

Blackburn, G.F., and F.R. Caldwell, Reference tables for thermocouples of iridium- rhodium alloys versus iridium, J. Res. NatI. Bur. Std. (U.S.) 68C, 41 ( Jan.-Mar.).

Bonilla, C.F., et al, Thermoelectric potentials of molten and refractory metals, N 64-20479.

Davisson, E.G., and R.K. Adams, Smoothed thermocouple tables, U.S. At. Energy Comm. Rept. ORNL-P-227; Proc. Instr. Soc. Am. 19, Paper No. 11, 1-3-64.

E isenste in, J.C., R.P. Hudson, and B. W. Mangum, A magnetic fixed point for thermometry below $10 \mathrm{~K}, \mathrm{Appl}$. Phys. Letters 5, 231 (Dec. 1 ).

Geörgian, J.C., The temperature scale, Nature 201, 695 (Feb. 15).

Hall, J.A., The pyrometric scale of temperaturebe tween 20 and $1063^{\circ}$, Comite Consultatif Thermometrie, Comite Intern. Poids Mesures, 6e, Sevres, France 1962, 72 .

Hall, J.A., and C.R. Barber, Calibration of temperature measuring instruments, Nat'l. Phys. Lab. (Gt. Brit.) Notes Appl. Sci. No. 12 (3rd. ed.).

Hauback, W.J., and W.L. Taylor, Measuring precisely near absolute zero; hel ium- 3 and low temperature thermometry, Research/Development 15, 19 (Sept.).

Hens inkveld, W.A., and K. Scheerer, comparison of the pyrometric scale of temperature of the University of Utrecht to those of N.P.L. and of P.T.B., Comite Consultatif Thermometrie, Comite intern. Poids Mesures, 6e, Sevres, France, 1962, 67 .
Heyne, W., Precision measurement for testing thermoelectric voltages and temperature relationships of $\mathrm{Pt-10 \%} \mathrm{Rh} / \mathrm{Pt}$ thermoelements by means of the solidification points of copper, aluminum and zinc, Feingeratetech. 13, 311 (July).

Heyne, w., Investigation of the determination of the relation of thermal emf and temperature of $\mathrm{P} \dagger 10 \% \mathrm{Rh}$ vs $\mathrm{P} \dagger$ thermocouples by means of the freezing points of metals, ExptI. Tech. Physik 13, 90.

Heyne, W., Determination of the freezing point of copper, ExptI. Tech. Physik 12, 87.

Lapp, G.B., and D.J. Popova, Calibration of tungsten-rhenium thermocouples, Measurement Techniques No. 10, 847 (Mar.).

Le Fevre, E.J., The temperature scale, Nature 203, 1158 (Sept. 12).

Lovejoy, D.R., Theory of two bands for high purity platinum and the reproducibility of the temperature scale, Comite Consultatif Thermometrie, Comite Intern. Poids Mesures, 6e, Sevres, France, 1962, 138. Magdeburg, H., A new me thod for realizing pyrometric fixed points, Z. Instrumentenk 72, $205(\mathrm{July})$.

Minard, D., Effective temperature scale and its modification, Naval Medical Research Inst. Bethesda, Md., Rept. 6, (Mar.); $A D-603186$; N64-30629.

Moser, H., and W. Thomas, Comparison of the practical international temperature scale with the thermodynamic scale between the zinc and gold points according to the most recent gas thermometer measurements, Comite Consultatif Thermometrie, Comite Intern. Poids Mesures, 6e, Sevres, France $1962,34$.

olsen, L.O., and P.D. Freeze, Reference tables for the Platinel II Thermocouple, J. Res. NatI. Bur. Std. (U.S.) 68C, 263 (Oct.).

Roberts, T.R., et al, The 1962 Helium- 3 scale of temperatures, U.S. At. Energy Comm. Rept . LADC- 5757 .

Sherman, R. H., et al, 1962 Helium-3 scale in 4 parts, NBS Journal 68A, pp 547, 559, 567 , \& 579 .

Spengler, W.E., and D.K. Graham, Equations and tables for thermocouples, $32^{\circ} \mathrm{F}$ reference junction, AD-432828; N64-17456.

Sydoriak, S.G., et al, The 1962 Helium-3 scale of temperature, J.Res. Nat I. Bur. Std. (U.S.) 68A, 547 .

\section{5}

Adams, R.K., and E.G. Davisson, Smoothed Thermocouple tables of extended significance $\left({ }^{\circ} \mathrm{C}\right)$ : platinum vs platinum- $10 \%$ rhodium thermocouples, Oak Ridge NatI. Lab., Tenn. Instrumentation and Controls Div., ORNL - 3649, Vol. 2, Sect. 2.1 (Mar.); AD 19-20263; N65-20680.

Adams, R.K., and E.G. Davisson, Smoothed thermocouple tables of extended significance $\left({ }^{\circ} \mathrm{C}\right)$ : platinum vs platinum-13\% rhodium thermocouples, ORNL-3649, Vol.2, sect. 2.2; AD-20264; N65-20681. 
Adams, R.K., and E.G. Davisson, Smoothed thermocouple tables of extended significance $\left({ }^{\circ} \mathrm{C}\right)$ : Chromel-Alumel thermocouples, ORNL-3649, Vol.2, Sect.2.3: AD20265: N65-20682.

Adams, R.K., and E.G. Davisson, Smoothed thermocouple tables of extended significance $\left({ }^{\circ} \mathrm{C}\right)$ : iron-constantan thermocouples, ORNL-3649, Vol.2, sect. 2.4: AD2.0266: N65-20683.

Adams, R.K., and E.G. Davisson, Smoothed thermocouple tables of extended significance $\left({ }^{\circ} \mathrm{C}\right)$ : copper-constantan thermocouples, ORNL-3649, Vol.2, Sect. 2.5; AD-20267: N65-20684.

Adams, R.K., and E.G. Davisson, Smoothed thermocouple tables of extended significance $\left({ }^{\circ} \mathrm{C}\right)$ : Chromel-constantan thermocouples, ORNL-3649, Vol.2, Sect. 2.6: AD-20267: N65-20684.

Adams, R.K., and E.G. Davisson, Smoothed thermocouple tables of extended significance $\left({ }^{\circ} \mathrm{C}\right)$ : tungsten vs tungsten-26\% rhenium thermocouples, ORNL-3649, Vol. 2, Sect. 2.7; AD-20269; N65-20152.

Adams, R.K., and E.G. Davisson, Smoothed thermocouple tables of extended significance $\left({ }^{\circ} \mathrm{C}\right)$ : tungsten-5\% rhenium vs tungsten-26\% rhenium tehrmocouples, ORNL-3649, Vol.2, Sect. 2.8; AD-20270; N65-20153.

Adams, R.K., and E.G. Davisson, Smoothed thermocouple tables of extended significance $\left({ }^{\circ} \mathrm{C}\right)$ : tungsten- $3 \%$ rhenium vs tungsten-25\% rhenium thermocouples, ORNL-3649, Vol. 2, Sect. 2.9; AD-20271; N65-20154.

Adams, R.K., and E.G. Davisson, Smoothed thermocouple tables of extended significance $\left({ }^{\circ} \mathrm{C}\right):$ gold-2.1\% cobalt vs copper cryogenic thermocouples, ORNL-3649, Vol. 2, Sect. 2.10; AD-20272; N65-20155.

Adams, R.K., and E.G. Davisson, Smoothed thermocouple tables of extended significance $\left({ }^{\circ} \mathrm{C}\right)$ : constantan-copper cryogenic thermocouples, ORNL-3649, Vol. 2, Sect. 2.11: AD-20273; N65-20156.

Adams, R.K., and E.G. Davisson, Smoothed thermocouple tables of extended significance $\left({ }^{\circ} \mathrm{C}\right)$ : Alumel-Chromel cryogenic thermocouples, ORNL-3649, Vol.2, sect. 2.12; AD-20274; N65-20157.

Adams, R.K., and E.G. Davisson, Smoothed thermocouple tables of extended significance $\left({ }^{\circ} \mathrm{C}\right)$ : constantan $(J N)$-iron $(J P)$ cryogenic thermocouples, ORNL-3649, Vol. 2. Sect. 2.13: AD-20275: N65-20158.

Adams, R.K., and E.G. Davisson, Smoothed thermocouple tables of extended significance $\left({ }^{\circ} \mathrm{C}\right)$ : constantan $(Y N)-\operatorname{iron}(Y P)$ cryogenic thermocouples, ORNL-3649, Vol. 2, Sect. 2.14; AD-20276: N65-20159.

Barber, C.R., and A. Horsford, Differences between the thermodynamic scale and the International Practical Scale. of Temperature from $0^{\circ} \mathrm{C}$ to $-183^{\circ} \mathrm{C}$, Metrologia 1,75 ( July).

Beattie, J.A.', et al, Experimental study of the absolute temperature scale, J. Chem. Phys. 42, 2274 (April).

Bedford, R.E., Reference tables for plat- i num $40 \%$ rhodium vs platimum $20 \%$ rhodium thermocouples, Rev. Sci. Instr. 36, 1571 (nov.).

DeBoer, J., Temperature as a basic physical quantity, Metrologia, 1, 158 (oct.).

Dingle, $H_{.}$, et al, Linear temperature scale, Nature 206, 1347 (June 26).

Furukawa, G.T., and M.L. Reilly, Application of precise heat capacity data to the analysis of the temperature intervals of the NBS (1955) and the international practical temperature scales in the region of $90^{\circ} \mathrm{K}, \mathrm{J}$. Res. Nat'l. Bur. Std. (U.S.) 69A, 5 (Jan.).

Grenis, $\overline{A . F .}$, and M.J. Matkovich, Blackbody reference for temperatures above $1200^{\circ} \mathrm{K}:$ Study for design requirements, Army Material Research Agency, Watertown, Mass., Tech. Rept. AMRA-TR-65-02; AD614638 .

Groves, W.D., and L. Lielmezs, The linear temperature scale, Nature 205, 489 (Jan. 301 .

Hall, J.A., The radiation scale of temperature between $175^{\circ} \mathrm{C}$ and $1063^{\circ} \mathrm{C}$, Metrologia 1,140 (Oct.).

MarshaTI, T.W., A classical treatment of blackbody radiation, Nuovo Cimento( $\mid$ taly) 38,206 ( July 1).

Rath, R., and R. Dubbe, Pyrometers and their calibration for production control, Fe inwk.-Tech. 69, 97 (March).

\section{Thermoelectric Devices}

1960

Adakhovskii, A.P., et al, New types of thermocouples for measuring temperatures up to $1800^{\circ}$, Tr. Vses. Nauchn.- Issled. Inst. Metrol. 1960, No. 42, 29.

Ciborowski, F., The effect of non-homogeneous thermocouple elements on the accuracy of $\mathrm{NiCr}-\mathrm{Ni}$ thermocouples, Prom. Avtomat. Kontrol 1960, No. 2, 64.

Kuether, F.W., The thermal emf scatter of rhenium, Rhenium Papers Symp., Chicago, 1960, 149.

Lachman, J.C., and J.A. McGurty, Thermocouples for $5000^{\circ} \mathrm{F}$, using rhenium alloys, Rhenium Papers Symp., Chicago 1960, 153.

$L$ 'vov, S.M., and V.F. Nemchenko, Tungstenmolybdenum thermocouple, Ezhegodnik Nauchn. Rabot, Khersonsk. Gos. Ped. Inst., Estestroznanie, Kherson 1960, 3.

Moeller, G.K., R.B. Branfi $\overline{n, \text { and }} P$. Whitmarsh, Error determination in high temperature thermocouple measurements, U.S. At. Energy Comm. Rept. K-T-552, (Nov. 30); NSA $18-12418$.

\section{1}

Green, S.J., and T.W. Hunt, Accuracy and response of thermocouples for surface and fluid temperature measurement, U.S. At. Energy Comm. Rept. WAPD- T-1270.

1962

Begot, R., and R. Faivre, Experimental 
study of the very rapid cooling obtained by direct quenching in water of solders on thermocouples, Compte Rend. 255, 3128 (Dec. 5).

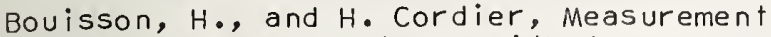
of surface temperatures with thermocouples. Effect of radiation received by the thermocouple and the method of attachment, Compt Rend. Acad. Sci. 255, 1296 ( Aug. 27).

Challe, J., Study of the dynamic behavior of thermowells, U.S. At. Energy Comm. Rept. NP-13288 (Sept.).

Cherpakov, P.V., The thermal inertia of thermocouples, Inzh. Fiz. Zh. 5, 94 (Sept.).

Ciborowski, F., Factors affecting constancy and stability of the thermoelectric characteristics of industrial thermocouples, Pomiary, Automat., Kontrola 8 , 509 (Nov.).

Doyle, J., High voltage electron beam welding of W- Re thermocouples, U.S. At. Energy Comm. Rept. CNLM-4351 (Dec. 13).

Fitzpatrick, V.F., Fretting corrosion of 1/8- inch $\mathrm{Zr}-2(Z y-2) \mathrm{clad}$ thermocouples, U.S. At. Energy Comm. Rept. HW75626 (Nov.).

Golubev, A.V., Influence of the electrochemical effect in thermocouples on the precision of temperature measurements, Materialy k Ucheniyu o Merzlykh Zonakh Zemnoi Kory., Akad. Nauk SSSR, Akad. Stroit. i Arklritekr., Inst. Merzotored. $8,113$.

Karasina, E.S., L.I. Kropp, and M.S. Mints Aplication of suction thermocouples for measuring high gas temperatures, Ind. Lab. 23, 665 (Dec.).

Kortum, H., G. Luck, and E. Stutter, Resistance measurement on thermocouples and thermopiles, Feingeratetech.11, 534 (Dec.).

Kroeckel, 0., High-temperature thermoelements, Abhandl. Deut. Akad. Wiss. BerI in, Kl. Math., Physik. Tech. 1962, No. 1,437 .

Kutateladze, K.S., et al, Sheaths for immersion thermocouples for measuring the temperature of molten metals, ogneupory $27,223$.

Margulis, 0.M., et al, Tips for immersion type thermocouples made from zirconium dioxide of increased resistance to heat, ogneupory 12, 552; AD-411058.

McGurty, J.A., and W.C. Kuhlman, Tungsten vs tungsten-rhenium thermocouple research and development, U.S. At. Energy Comm. Rept. TID-20944.

Morita, Y., Average temperature measurements using thermocouples, Bull. Tokyo Inst. Technol. No. 50, 27.

olszewski, J., Effect of thermocouple sheathing on reading temperatures of blast-furnace blast, Hutnik 29, 366.

owczarski, W.A., Tungsten-rhenium thermocouples for difficult measurements of Zircalloy-2 wel dments, U.S. At. Energy Comm. Rept. TID-17734.

Plyukhin, V.S., and V.N. Kologrivov, Emf of thermocouples compressed by a shock wave, Zh. Prikl. Mekhan. i Tekn. Fiz. No. 5, 175 (1962); A ir Force Systems Command, Wright Patterson AFB, ohio, Foreign Technology Division FTD-TT-63-1057/1 and 2; $A D-426901$; N64-23314.

Shaidurov, G.F., Measurement of the temperature of a wall, Inzh. Fiz. Zh. 5, 86 (Dec).

Stottman, P., Measuring high temperature gas flames with thermoelectric elements, Wiss. Ges. Luft - u Raumfahrt, Cologne (W. Germany) Proc. of the joint meeting of the comm. on air-breathing engines, and the Subcomm. on areodynamic measuring techniques (July 6, 1962); N64-20181.

Vasanova, L.K., et al, The measurement of temperature in poly-dispersion media during induction heating, Inzh. Fiz. Zh. 5, 82 (April).

W-Re takes Zircalloy-2's temperature, Am. Machinist 106, 122 (Nov.).

\section{3}

Adorni, N., and A. Parmaggiani, Device for high accuracy measurement of wall temperature using thermocouples, Energia Nucl. 10,34 .

Berman, R., and D.J. Huntley, Dilute goldiron alloys as thermocouple material for low-temperature heat conductivity measurements, Cryogenics 3, 70.

Bertodo, R.J., A thermocouple for the measurement of gas temperatures up to $2000^{\circ} \mathrm{C}$, Proc. Inst. Mech. Engrs. (London) 177, 603.

Bertodo, R.J., Thermocouples for use in oxidizing atmospheres at high temperatures, $R$ and $D$ No. 20, 62 (April).

Bostwick, W.E., Some experiences with noblemetal, metal-sheathed thermocouples, U.S. At. Energy Comm. Rept. UCRL-7361 (May 10, 1963).

Bragin, B.K., G.B. Lapp, and I.R. Lepin, Effect of annealing on the thermal electromotive force of platinum-rhodium thermocouples, Tr. Inst. Kom. Standartov, Mer. i Izmerit. Priborov pri Sov. Min. SSSR $1963(71), 220$.

Bull is, L.H., Vacuum-deposited thin $\mathrm{film}$ thermocouples for accurate measurement of substrate surface temperature, J.Sci. Instr. 40, 592 (Dec.).

Chambers, J.T., D.L. Rall, and W.H. Geidt, Experimental evaluation of a dual-element transducer for high temperature gas measurements, Aeron. Res. Labs. Office of Aerospace Res., U.S. Air Force Rept. ARL 63-58; AD-409816.

Cox, J.E., High vacuum thermocouple, Rev. Sci. Instr. 34, 931 (Aug.).

Danishevskii, S.K., et al, Tungsten-rhenium alloy thermocouples for the measurement of temperatures up to $2500^{\circ}$, Zavosk. Lab. 29, 1139.

Deniidenko, I.I., N.J. Mitina, and V.G. Padalka, Investigation of plasmoids by means of a thermocouple, Ukrain. Fiz. Zh. 7, 61 ( Jan.).

de Sigoyer, B.B., F. Jaques, and P. Thome, Zircalloy sheathed fuel element rods fitted with thermocouples, U.S. At. Energy 
Comm. Rept. CEA-2290.

Dougherty, L.W., Thermocouple hot-junction mounting techniques, Tech. Memo. SL-M-15; AD-290914.

Efremova, R.l., et al, Temperature measurements by means of copper-constantan thermocouples, Measurement Techniques No. 3, 214 (Sept.).

Gross, J., and C.B. Griffith, A thermocouple for molten steel, Metal Progr. 83, 106 (June).

Hahnemann, H.W., Thermoelements for measuring gas temperatures up to $2000^{\circ} \mathrm{C}$, Forsh. Geb. Ingen-Wes. 29, 203.

Ham, A.C., and R.E. Jones, Some measurements on thermocouples subjected to radiation, Royal Aircraft Establ ishment, Farnborough, England, RAE-TN-S TRUCT-343 (Oct. 1963); AD-433035; N65-25351.

Hick, E.W., The requirements for a direct reading $5000^{\circ} \mathrm{F}$ Thermocouple, Proc. InStr. Soc. Am. 18, Paper No. 29.2.63.

Hughes, P.C., and N.A. Burley, Metallurgical factors affecting stability of nickel-base thermocouples, J. Inst. Metals $91,373$.

Janeschitz-Kriegel, $H_{\text {., }}$ et al, A temperature probe for flowing polymer melts, J. Sci. Instr. 40, 415 (Aug.).

Koslapov, $V_{\text {., }}$ and $\bar{Y} u$. M. Skvortsov, Thermocouple needle, Ind. Lab. 28, 1474 $(\mathrm{Ju} \mid \mathrm{y})$.

krysiak, K.F., et al, A thermocouple suitable for use from 2500 to $4500^{\circ} \mathrm{F}$ on aerospace vehicles, ASD-TDR-63-592; AD414562.

Kuhlman, W.C., Research and evaluation of materials for thermocouple application suitable for temperature measurements up to $4500^{\circ} \mathrm{F}$ on the surface of guide reentry vehicles, Wright Patterson AFB, ohio, ASD-TDR-63-233; AD- 404577.

Lakh, V.I., B.l. Stadnyk, and Yu.B. Kuzma, Thermoelectric stability of thermocouples made of tungsten-rhenium alloys at high temperature, High Temperature 1 , 267 (sept.-Oct.).

Ling, F.F., and T.E. Simkins, Measurement of pointwise juncture condition of temperature at the interface of two bodies in sliding contact, Trans. ASME $1 \mathrm{~J}$. Basic Eng.1 85D, 481 .

Loskutov, $V_{\text {. I. }}$, New me thod of measuring the temperature of molten steel, Instr. Construct. No. 11, 9 (Nov.).

Lyusternik, $V: E$., Reproducibility of the calibration of platinum vs platinum rhodium thermocouples over a wide temperature range, High Temperature 1, 120 ( $\mathrm{J} \cup \mathrm{ly}-\mathrm{Aug}$.).

Moeller, C.E., Special surface thermocouples, Instr. Control Systems 36, 97 (May).

Moen, W.K., Use thermocouples right and melt away weight, Abstract: S.A.E. J. 71,58 (Nov.).

Morrison, R.D., and R.R. Lachenmayer, Thin film thermocouples for substrate temperature measurement, Rev. Sci. Instr. 34, 106 (Jan.).

Nanigan, J., Thermal properties of ther- mocouples, Instr. Control Systems 36, 87 (Oct.).

Nanigan, J., Matching TC well material to wall improves accuracy, ISA J.10,75 (Feb).

oetken, E.R., Evaluation of surface attached thermocouples during forced convection heat transfer, U.S. At. Energy Comm. Rept. IDO-16889.

Panasyuk, A.D., and G.V. Samsonov, Thermocouples with electrodes of refractory carbides for use up to $3000^{\circ} \mathrm{C}$, High Temperature 1,116 (July-Aug.).

Pokhodnya, T.K., and 1.1. Fruman, The temperature of a weld pool, AD-400930.

Rainy, W.T. Jr., and R.L. Bennett, Stability of base metal thermocouples in helium atmospheres, ISA Trans. 2, 34 (Jan.).

Reichardt, F.A., Measurement of high temperatures under irradiation conditions, Platinum Me tals Rev. 7, 122 (oct.).

SabadelI, A.J., and J. Wenograd, The measurement of the temperature profiles of burning solid propellant by microthermocouples, Princeton U., Guggenheim Labs. Aeronaut. Eng. Rept. 664; AD-422387.

Schmidt, A.J., A hall generator arrangement for the measurement of small temperature differences in metals, Z. Naturforsch 18a, $37(\mathrm{Jan}$.$) .$

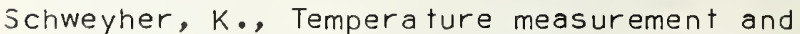
heat distribution during heat treatment in an electrically heated experimental furnace, Stahl u Eisen 83, 1162 (Sept. 12).

Sharp, J.D., Rapid immersion pyrometry with expendable couples, Iron and Steel 36, 320 ( June).

Sharp, J.D., Expendable-Tip thermocouples, Metal Ind. $102,556$.

Sharp, J.D., Continuous temperature measurement of molten steel, Platinum Metals Rev. 7, 90 (July); J. Metals 15, 902 (Dec.).

Skoglund, V.J., and D.M. Yano, The development of a temperature probe and temperature survey of the interaction of an oblique shock wave and a turbulent boundary layer, U.S. At. Energy Comm. Rept. SC-DC3565 (Oct.).

stamper, J.A., Differential sensing controlled thermocouple, Rev. Sci. Instr. 34, 444 (April).

Stevenson, J.A., Temperature measurement with the expendable immersion thermocouple, Platinum Metals Rev. 7, 2 (Jan.).

Thomas, D.B., Studies on the tungsten-rhenium thermocouple to $2000^{\circ} \mathrm{C}$, J. Res. Nat'l. Bur. Std. (U.S.) 67C, 337 (OCt.).

vanvor, H., Special problems in the use of thermocouples for the measurement of temperatures above $1500^{\circ} \mathrm{C}$, Ber. Dtsch. Keram. Ges. 40, 615.

Vlasov, $v \cdot v_{\cdot}$, Results of testing batteries of differential thermocouples, Instr. Construct. No. 4, 28 (April).

Wechter, G.H., The accuracy of thermocouples in measuring surface temperatures of stainless steel specimens subjected to radiant heat, Aeronaut. Structures Lab., Naval Air and Engineer ing Center, Phila., Pa., Rept. NAES ASL13R360FR101 (july 10); AD-412317. 
We issenberger, E.G., Metal sheathed thermocouples, Instr. Control Systems 36, 109 (May).

Wormser, A.F., and R.A. Pfuntner, Pulse thermocouple measures at $5700^{\circ} \mathrm{F}$, Spacel Aeronautics $40,116(\mathrm{Ju} / \mathrm{y})$.

Zysk, E.D., D. $\bar{A}$. Toenshoff, and J.Penton, Tungsten $3 \%$ rhenium vs tungsten $25 \%$ rhenium, a new high temperature thermocouple, Engelhard Inds. Tech. Bull. 3, 130 (Mar.).

Gold thermocouples in cryogenic investigations, Design Electron. 1, 9 (oct.). Improved thermocouple techniques for safe operation of modern boilers, Power 107 , 54 ( Jan.).

More on welding thermocouples, ISA J. 10, 76 (April).

Pyrometer for moving surfaces, Mech. Eng. 85, 76 (May).

Surface temperature measurements with thermoelectric materials, $A D-286098$.

Unusual thermocouples and accessories, Instr. Control Systems 36,91 (May)

$\begin{array}{llll}" 1 & " 1 & \underline{36}, & 110 \text { ( June) } \\ " & " & " & \underline{36}, 99 \text { (July) } \\ " & " 130 \text { (Aug.). }\end{array}$

\section{4}

Adsi $\dagger \dagger$, C.L., Minimization of carbon deposit grounding effects on thermocouple measurements, AD- 448821 .

Allen, J.G., and C.D. Pears, Evaluation of the performance of tungsten-tungsten 26 rhenium thermocouples to about $5000^{\circ}$ F, NASA Rept. CR-55626; N64-16269.

Alvermann, $W_{.}$, and $P$. Stottmann, Temperature measurements in combustion gases by means of thermocouples, N65-16643.

Beck, J.V., Correction of transient thermocouple temperature measurements in heat-conducting solids, $\mathrm{AD}-445633$.

Bennett, R.L. et al, Stability of thermoelectric materials in a helium-graphite environment, U.S. At. Energy Comm. Rept. ORNL-TM- 746 .

Berman, R., J.C.F. Brock, and D.J. Huntley, Properties of gold +0.03 percent ( $A t_{.}$) iron thermoelements between 1 and $303^{\circ} \mathrm{K}$ and behaviour in a magnetic field, Cryogenics 4,233 (Aug.).

Bradfield, W.. $\bar{S}$., A.R. Hanson, and J.J. Sheppard Jr., Design, calibration, and application of a miniature total temperature probe, Trans. ASME (J. Heat Transfer) 86, 462 (Aug.).

Bragin, B.K., and R.N. Tetyueva, Thermoelectric uniformity of Chromel, Copel, Alumel and copper wire at low temperatures, Measurement Techniques No.6, 498 (Dec.).

Byrne, M.F., Thermocouple introduced into vessel under pressure, Chem. Eng. 71, 154 (Nov. 23).

Carlson, A.V., Radiation compensating thermocouple temperature sensors, Intern. Convention on Military Electronics, 8th., Wash., D.C., Sept. 14-16, 1964 Conference Proc, p. 171.

Chevallier, J.P., Transitory response of thermal receptors utilizing thermocouples, France, O.N.E.R.A. TP-157.

Clark, R.3., Calibration and stability of W/W Re thermocouples to $2760^{\circ} \mathrm{C}\left(5000^{\circ} \mathrm{F}\right)$, Proc. Instr. Soc. Am. 19, Paper No. 15, (Nov.4).

Collins, C.G., organic, structural and control materials, U.S. At. Energy Comm. Rep†. APEX-917.

Cookson, R.A., P.G. Dunham, and J.K. Kilham, Non-catalytic coatings for thermocouples, Combust. Flame 8,168 (June).

Crisp, R.S., and $\bar{W} \cdot G$. Henry, The design of a low temperature thermocouple material, Cryogenics 4, 361 (Dec.); AD-614881.

Czohara, E.A., Res istance welding of strain gages and surface thermocouples, $A D-448$ 518.

Dalle Donne, M., Tests and data concerning platinel, a new high temperature thermocouple, Engelhard Inds. Tech. Bul|. 5, 5 ( June).

Danburg, J.E., The equilibrium temperature probe. A device for measuring temperatures in hypersonic boundary layers, Naval Ordnance Lab., White Oak, Md. TR612; AD-439624.

Danishevskii, S.K., et al, Thermocouples made of tungsten alloys with rhenium for measuring temperatures up to $2500^{\circ} \mathrm{C}$, Ind. Lab. 29, 1242 (Mar.).

Dinian, J., Thermocouples, CEA-Bib-34; NSA $\mathrm{N}-18132$.

Dow, M.B., Comparison of measurements of interval temperatures in ablation mate$r$ ials by various thermocouple configurations, NASA Tech. Note D-2165 (Nov.).

Dunbar, W.G., High temperature effects on ceramic insulated thermocouple wires, Trans. Inst. Elect. Electron. Engrs. As-2, 452 (April).

Fricke, H.W., Miniature encased thermocouple for the highest mechanical efficiency, Rigelungstech. Praxis 6, 173.

Furey, M.J., Surface temperatures in sliding contact, Trans. Am. Soc. Lubrication Engrs. 7, 133 (April).

Gaevski, M.M., Errors in dynamic calibration of thermoelectric transducers with differences between their thermal inertias, Measurement Techniques No. 8, 665 (Feb.).

Gelb, G.H., B.D. Marcus, and D. Dropkin, Manufacture of $f$ ine wire thermocouple probes, Rev. Sci. Instr. 35, 80 (Jan.).

Gross, P.M., et al, A re-entry thermocouple for use up to $4500^{\circ} \mathrm{F}$, ISA Trans. 3, 305.

Heitzman, W.P., Dual- thermocouple Femperature controls, Instr. Control systems 37 , 109 (May).

Hensel, R., and M. Gohler, Tests with a tungsten/molybdenum immersion thermocouple for measuring the temperature of steel melts, Neue Hutte 9, 237 (April).

Hicks, E.W, Investigätion of tungsten vs tungsten-26 percet rhenium thermocouples above $3500^{\circ} \mathrm{F}$ in oxidizing environments, Proc. Instr. Soc. Am. 19, Paper No. 16 (oct.3).

Hurst, N.J., Effect of thermocouple size and installation on temperature readings, Army Missile Command, Huntsville, Ala. 
RS-TM-64-1; AD-612493; N65-20521.

Irvine, F.H., J.Picken, and G.H. Greenwood, Measurements of the response of various thermocouple arrangements, Royal Aircraft Establishment, Farnborough, England, RAE-TN-AERO-2959 (April): N65-20514.

Jensen, J.T., J.Klebanoff, and G.A. Haas, Thermocouple errors using $P t-P t(R h)$ thermocouples on $\mathrm{Ni}$ surfaces, Rev. Sci. Instr. 35, 1717 (Jec.).

Klein, C.A., and M.P. Lepie, operational performance characteristics of pyrolytic graphite thermocouples, Solid state Electronics 7, 241 (April).

Klein, C.A. et al, Development of an ultra high temperature pyrolytic graphite thermocouple, ASD-TDR-63-844; AD-431203; N64-16594.

Kornilov, V.V., and B.I. Makarov, Measurement of rapidly changing temperatures of conducting solid bodies by means of thermocouples, Measurement Techniques No. 10, 849 (Mar.).

Kovacs, A., and R.B. Mesler, Making and testing small surface thermocouples for fast response, Rev. Sci. Instr. 35, 485 (April).

Lagedrost, J.F., Laboratory studies toward improvement of high-temperature thermocouples, U.S. At. Energy Comm. Rept. TID 7697.

Lapp, G.B., and D.L. Popova, Certain thermometric properties of tungsten-rhenium thermoelectrodes, Measurement Techniques No. 11, 917 (April).

Leto, F., Source approval for thermocouple specification, NA5-2722, NA5-27230, NA5-27256, NA5-27290, NA5-27334, NA527340, and NA5-27344, Rocketdyne, Canoga Park, Calif. Rept. No. E-438-40; AD470412 .

Lorch, H.R., Mineral insulated thermocouples, Euronuclear 1, 42 (Sept.).

McCausey, R.J., and $\bar{E} \cdot$ R. Funk, A high accuracy primary-element-system for temperature measurements in turbine performance tests, Proc. Instr. Soc. Am. 19, Paper No. 15 (Jan. 1).

Markovskii, E.A., and M.M. Krasnoshchekov, Measurement of the temperature of friction surfaces of parts by means of a junctionless thermocouple, Ind. Lab. 29, 1203 (Mar.).

Middlehurst, j. et al, Electrochemical effects in thermocouples, J. Sci. Instr. 41,676 (Nov.).

Moen, W.K., Spacecraft thermocouple installation design, Proc. Instr. Soc. Am. 19, Paper No. 16 (oct. 2).

Moran, J., Molten metal temperature measurement by expendable thermocouples, Instr. Pract. 18, 1033 (oct.).

Mulcahy, E.L., A Tt achment techniques for the "C" section tests in the space environment simulator, AD- 439157.

Nanigan, J.., Temperature measurements in the $3000^{\circ} \mathrm{F}$ to $5000^{\circ} \mathrm{F}$ range using ribbon thermocouples, ISA Annual Conference, 19 th New York, N.Y., (Oct. 19).

Palmer, E.P., and G.H. Turner, Response of a thermocouple junction to shock waves in copper, J. Appl. Phys. 35, 3055 (oct.).

Pletenetskii, G.E., Thermocouple for measuring high temperatures in vacuum and helium, Ind. Lab. 30, 786 (Dec.).

Pletenetskii, G.E., and A.T. Mandrich, Testing of thermoelectrode metals in helium at $1500^{\circ}$, Zavosk. Lab. 30, 1243.

Raag, $V_{.,}$Silicon-germani um thermocouple development, N64-17386.

Ramachandran, S., and T.R. Acre, Measuring molten steel temperatures, ISA J.11, 54 (mar.).

Robinson, J.E., Thermoelectric junctioning project, $A D-430243$.

Rosenbaum, R.L., R.R. oder, and R.B. Goldner, Low temperature thermoelectric power of gold-iron vs copper thermocouples, Cryogenics 4, 333 (oct.).

Sabadell, A.J., J. Wenograd, and M. Summerfield, The measurement of temperature profiles through solid propellant flames using $f$ ine theemoocooouples, N64-14547.

Sarychev, G.S., I.M. Veselnitski i, and G.N. Rokhlin, New technique for fixing surface thermocouples, Measurement Techniques No. 9, 753 (Feb.).

Semkina, N.V., N.M. Permikina, and T.N. Kodryartseva, Corundum heat-resistant shields for immersion thermocouples, $\mathrm{Tr}$. vost. Inst. ogneuporov $\underline{5}, 49$.

Stadnyk, B.1., and G.V. Sämsonov, Thermocouples for measuring high temperatures, High Temperature 2, 573 (July-Aug.).

Thomson, A., The the rmal response time of sheathed mineral-insulated thermocouples, U.S. At. Energy Comm. Rept. 658 (R).

Truchasson, C., Making very $f$ ine heat probes for the measurement of temperatures in water, J.Phys. (France) 25 Supplement No. 3, 17A (Nar.).

Turner, R.C., and G.D. Gordon, Thermocouples for vacuum tests minimizes errors, Space/ Aeronautics 41, 256 ( Jan.).

Vickers, P.T., Proper probes keep thermocouples reading true, S.A.E. J. 72, 54 (Dec.).

Vidadi, Yu.A., Thermocouple with a compen sating heater, Pribory Tekh. Eksper. (USSR) No. 6, 152 (Nov.-Dec.): Instr. Exp. Tech. No. 6, 1301 (May 1965).

Wormser, A.F., and R.A. Pfuntner, Pulse technique extends range of Chromel-Alumel to $7000^{\circ} \mathrm{F}$, Instr. Control systems 37, 101 (May)."

Continuous immersion thermocouple aids blast furnace control, Iron \& Steel Eng. 41, 179 $(J u \mid y)$.

\section{5}

Alvermann, $W_{.}$, and $P$. Stottmann, Temperature measurements with thermocouples in combustion gases, NASA-TT-F-9537; N65-33954.

Bailey, H.T., Procedure is simple for making thermocouples, Foundry 93, 226 (May).

Brooks, E.J., and E.W. O'Neal, Keep your thermocouple leads dry, ISA J. 12, 94(Mar.).

Cheesewright, R., A technique for stripping small diameter metal sheathed thermocouple wire, J.Sci. Instr. 42, 815 (Nov.). 
Chichinadze, A.V., E.D. Braun, and A.G. Abukumkin, Thermocouples for the investigation of materials in friction, Ind. Lab. 31; 928 (June).

Cooper, M.G., and A.J.P. Lloyd, Miniature thin film thermometers with rapid response, J.Sci. Instr. 42, 791 (Nov.).

Daniells, G.E., Measurement of gas temperature and the radiation compensating thermocouple, Inst. of Environmental Sci. Annual Tech. Meeting, 11 th, Chicago, $111 .$, April 21-23, 1965 Proc. A6529982 19-11.

Devita, V.A., Predicting cryogenic thermocouple time constant, Control Eng. 12, $63(\mathrm{Ju} \mid \mathrm{y})$.

Fanciullo, S., Drift and endurance testing of Chromel/Alumel, W- 5 Re/W-26 Re and Mo/W-26 Re thermocouples at 1950$2000^{\circ} \mathrm{F}$ for 10,000 hours, U.S. At. Energy Comm. Rept. PWAC-454; N65-17407.

Finnemore, D.K., J.E. Ostenson, and T.F. Stromberg, Secondary thermometer for the 4 to $20^{\circ} \mathrm{K}$ range, Rev. Sci. Instr. 36 , 1369 (Sept.)

Finnemore, D.K., et al, AuFe vs Cu Thermocouples, N65-13852.

Genet, F., and B. Milloit, Mesure du temps de remataux de thermocouples dans les dircuits de metaux I iquides, European Atomic Energy Community, Ispara, Italy EUR-2281. F; NSA 19-22659.

Gordov, A.N., et al, An experimental investigation of the inertia of microthermocouples, High Temperature 3,268 (Mar.-April).

Farrow, R.L., and A.P. Levitt, Tungsten/ tungsten-rhenium thermocouples in a carbon atmosphere, Army Materials, Research Agency, Watertown, Mass., Materials Eng. Div. Rept. AMRA-TR-64-12, July 1964; $A D-606565$; N65- 10886.

Hall, B.F. Jr., and N.F. Spooner, Study of high temperature thermocouples (Final Rept.) AFCRL-65-251; AD-619038; N65-36842.

Hanneman, R.E., and H.M. Strong, Pressure dependence on the emf of thermocouples to $1300^{\circ} \mathrm{C}$ and $50 \mathrm{~K}$ bar, J. Appl. Phys. 36 , 523 (Feb.); ASME Preprint No. 64WA /PT-21 (Dec. 1964).

Hendricks, J.W., and D.L. MCEIroy, High temperature high vacuum thermocouple drift, Oak Ridge NatI. Lab., Tenn. ORNLP-1069: NSA 19-20278.

Kamenetskii, A.B., and N.V. Gul'ko, Interaction of thermal electrodes in tungsten-rhenium thermocouples with pure oxides insulation, Measurement Techniques No.6, 506 (June).

Kisliy, P.S., and M.A. Kuzenkova, Gas impervious protective coatings for thermocouples made of zirconium boride Poroshkovaya Me ${ }^{\prime}$., Akad. Nauk Ukr. SSR No. 1, 32; Rev. Metal Li†. 22, No. 5 (May 1965).

Klapper, J.A., et al, High temperature corrosion of constantan thermocouple conductors, mater. Protect 4, 72 .

Kocho, V.S., et al, Operation of thermocouple tips made from zirconium boride in the Bessemer convertor, Poroshkovaya Met., No. 3, 88.

Makarov, B.1., Errors in temperature measurement on the surface of a sol d body using a thermocouple when heating and cooling follow an arbitary law, NASA-TTF-9496: N65-29736.

Mat thew, H.L., Thermocouple calibration in subsonic air flow, Wyoming Univ., Laramie Masters Thes is AD-617305; N65-31753.

McCoy, H.E. Jr., Influence of $\mathrm{CO}-\mathrm{CO}_{2}$ environments on the calibration of Chromel P-Alumel thermocouples, Oak Ridge Nałl. Lab., Tenn. ORNL-P-1070; NSA 19-22654.

Novak, P.E., and R.R. Asamoto, Evaluation of thermocouples for use to $2600^{\circ} \mathrm{C}$ in mixed-oxide fuel, Trans. Am. Nucl. Soc. 8, 388 (Nov.).

Pak, V., and Yu.P. Krinskii, Thermoelectric method for measuring the mean temperature of metallic specimens, Ind. Lab. 30, 1033 (Feb.)

Phillips, L.S., The Measurement of thermoelectric properties at high temperatures, J. Sci. Instr. 42, 209 (April).

Pinchevski i, A.D., Transfer functions for commercial thermoelements, Measurement Techniques No. 5, 416 (May).

Rollinger, C.N., Convectively cooled thermoelements with variable cross sectional area, J. Heat Transfer 87, 259.

Sabadell, A.J., et al, Measurement of temperature profiles through solid propellant $f$ lames using fine thermocouples, A|AA J. 3. 1580 (Sept.).

SaTzano, F.J., Stability of a rhenium-graphite thermocouple, U.S. At. Energy Comm. Rept. BNL-8812.

Samsonov, G.V., and P.S. Kislyi, Protective sheaths of thermocouples for the continuous control of the temperature of molten metals, ogneupory No. 4, 28.

Smith, R.R. Jr., High temperature thermocouple research and development program, NASA-CR-67348; N65-35412.

Appendix 1: Drawings and design notes NASACR-67196, T-1097; N65-35416.

Appendix 2: Cal ibrations NASA-CR-57197, T-1097; N65-35415.

Appendix 3: Miscellaneous technical data NASA-CR-67347, T-1097; N65-35358.

Appendix 4: New technology NASA-CR-67195, T-1097; N65-34904.

Sparks, L.L., and R.L. Powell, Available low temperature thermocouple information and services, Nat1. Bur. Std., Boulder, Colo., NASA-CR-63149; NBS-8750; N65-25244.

Studennikov, Yu. A., and G.E. Erkovich, Compensation wires for VR5/20 thermocouples (exchange of experience) Ind. Lab. 31, 469 (Mar.).

Svede-Shvets, N.l., et al, Thermoelectric characteristics of metallic sintered alloys on a tungsten and molybdenum base, FTD-TT-65-642; AD-619334; NSA 19-47019.

Tal Iman, C.R., Analytical model for study of thermocouple error attributed to electrical conduction in insulation, Los Alamos Scientific Lab., Univ. of Calif., (N. Mex.). Contract W-7405-eng-36.

Thomson, A., The thermal response time of 
sheathed mineral-insulated thermocouples, Trans. Soc. Instr. Technol. 17, 49 (June).

Tschang, P.S., Temperature determination in moderately dense, high-temperature gases by transient thermocouple probes, Columbia Univ., New York ARL-65-95; AD-617702: N65-30297.

Ubbelohde, A.R., The anisotropy of graphite, Endeavour 24, 63 (May).

Van Drasek, J.J., and B.A. Short, Conversion formulas for copper-constantan thermocouples, Instr. Control Systems 38, 106 (Feb.).

WaTker, B.E., C.T. Ewing, and R.R. Miller, Instability of refractory metal thermocouples, Rev. Sci. Instr. 36, 816; NRL$6231 ; A D-621484$.

Walker, B.E., et al, study of the instability of noble metals in vacuum, Rev. sci. Instr. 36, 601 (May); NRL-6236; $A D-620322 ; N \overline{65}-36740$.

Yakimov, A.V., V.A. Sipailov, and Yu. A. Kazimirchik, Thermocouple calibration for temperature measurements in the grinding zone, Ind. Lab. 31, 1018 (July)

Zabawsky, Z., and F.M. Gavan, Thermocouples and their usage in ASTM standards, Mater. Res. Std. 5, 80 (Feb.).

Zenin, A.A., On hea $\bar{t}$ exchange of microthermocouples under conditions of combustion of condensed substances, N6530419 .

Zuikov, N.V., et al, A thermocouple for measuring temperature up to $2500^{\circ} \mathrm{K}$, Teplofizika Vysokikh Temperatur 3 , 815 (Sept.) Russian.

A rhodium-platinum thermocouple for high temperatures, Platinum Metals Rev. 9, 9 ( Jan.)

Evaluation of the pperformance of seven refractory metal thermocouples (Final Rept.) Southern Research Inst., Birmingham, Ala. NASA-CR-63809; N65-28366.

\section{RESISTANCE DEVICES}

1958

de Vroomen, A.R., Practical interpolation procedure for carbon thermometry between 1.5 and $30^{\circ} \mathrm{K}$, Probl. Low Temp. Phys. Thermodyn., Proc. Meeting Comm. I, Intern. Inst. Refrig., Delft, Neth., p. 137.

Sachse, H.B., Thermistors as sensing elements for low temperatures, Probl. Low Temp. Phys. Thermodyn., Proc. Meeting Comm. I, Intern. Inst. Refrig., Delft, Neth., p. 154 .

van Dijk, H., Platinum resistance thermometers between 90 and $4^{\circ} \mathrm{K}$, Probl. Low Temp. Phys. Thermodyn., Proc. Meeting Comm. I, Intern. Inst. Refrig., Delft, Neth., p. 155 .

\section{0}

Yaryshev, N.A., and A.S. Makhnovetski $i$, on the errors occurring in the measurement of non stationary surface tempera- tures, Priborostroenie 3, No. 6, 100.

\section{1}

Somers, L.M., The variation of $\left(K_{P} C_{P}\right)^{\frac{1}{2}}$ with temperature in 'Pyrex', Cornell PAeronaut. Lab., Buffalo, N.Y. Rept. CAL-106; AD279897 ; N65-10672.

\section{2}

Alieva, T.Z., and V.P. Chekulaev, Design characteristics of resistance thermometers, Tr. Inst. Kom. Standartov, Mer i Izmerit., Priborov Pri Sov. Min. SSSR 1962 No. 63, 218.

Cherepin, V.T., Measurement of temperatures at high rates of heating and cooling, Ind. Lab. 28, 211 (Aug.).

Corruccini, R.J., Cryogenic temperature measurement with platinum resistance thermometers- is fixed-point calibration adequate, Proc. Instr. Soc. Am. 8, 139.

Golovashkin, A.I., and G.P. Motulevich, A sensitive low-inertia thermal resistor for helium temperatures, Instr. Exp. Tech. No. 2, 404 (Nov.).

Gunbin, B.L., Instrument for remote measurement of temperature of moving media, Measurement Techniques No.4, 288 (Sept.).

La Fond, E.C., The Usnel thermistor chain, Navy Electronics Lab., San Diego, Calif. Rept. No. NEL-1114; AD-471158.

McAllan, J.V., Comparison of resistance thermometers used to measure freezing points of metals, Comite Consultatif Thermometrie, Comite Intern. Poids Mesures, 6e, Sevres, France 1962 P.52.

Mikhailov, N.N., and A. Ya. Govor, Lead brass resistance thermometers for low temperature measurement, Pribory i Tekh. Eksper. 1962, 180 (Mar. - April).

Raymond $J \cdot \overline{R .,} A$ well water tempetature lagging system, U.S. At. Energy Comm. Rept. HW-73994.

Riddle, J.L., Constant of the interpolation formula for platinum resistance thermometers, Comite consultatif Thermometrie, Comite Intern. Poids Mesures, 6e, Sevres, France 1962, 198.

Sokolov, Yu.E., Miniature copper resistance thermometer with an unbalanced bridge, Measurement Techniques No. 2, 126 (July).

\section{3}

Abichandani, C.T., P.T. Bhatt, and E.N. $B$ lagoveschensk $i$, wire res istance thermometers for determining soil temperatures, Res. Ind. (New Delhi) 8, 257.

Adirovich, E.1., S.P. Luñezhev, and E.I. Chernomorskaya, Application of thermistors to cryoscopic measurements, Dokl. Akad. Nauk UZ. SSR 20, No. 9, 18.

Andirch, E., and T. Van der Sterre, Structure and properties of thermistors, Elektron. Rundschau 17, 63 (Feb.).

Alieva, F.Z., Calibration of platinum resistance thermometers at two points, Measurement Techniques No. 11, 931 (June).

Alieva, F.Z., Measuring temperature in 
the -182.97 to $+630^{\circ}$ range with a platinum resistance thermometer calibrated at two points, Tr. Inst. Kom. Standartov, Mer i I zmerit. Priborov pri Sov. Min. SSSR 1963 No. 71, 134.

Barber, C.R., Low temperature platinum resistance thermometry, Platinum Metals Rev. 7, 15 (Jan.).

Beck, $A . E ., L i g h t w e i g h t$ borehole temperature measuring equipment for resistance thermometers, J.Sci. Instr. 40, 452 (Sept.).

Berry, R.J., Relationship between the real and ideal resistivity of platinum, can. J. Phys. 40, 946.

Brodski $i, A \cdot \bar{D} .$, Measuring low temperatures with a platinum resistance thermometer without calibration at the oxygen boiling point, Tr. Inst. Kom. Standartov Mer i lzmerit. Priborov pri Sov. Min. SSSR 1963 No. $71,149$.

Clark, J.N., J.A. Spahr, and R.A. Hendle, The effect of freezing-thawing cycles on thermistor calibration, PB 162793.

Cook, J.C., and K.E. Kenyon, Fast-response thermistor probes for temperature microstructure studies at sea, Rev. Sci. Instr. 34, 496 (May).

Dunn, W.F., A temperature measuring system using RDF Stilson resistance elements, Allegany Ballistics Lab., Rept. ABLE 87: AD-408503.

Godin, M.C., A modified thermistor thermometer, J. Sci. Instr. 40, 500 (oct.).

Golovashkin, A.N., and G.P. Motulevich, a sensitive low inertia thermal resistor for helium temperatures, cryogenics 3 , 167 (Sept.).

Hinkelmann, H., and H.M. Ihme, An electrical dep-sea thermometer with short ad justment time, $Z$. Angew. Phys. 15, 429.

Hoover, H.M., A rapid response high accuracy thermal probe, Marine Sci. Instr. $\underline{2}, 43$.

James, B.W., and B. Yates, Indium resistance thermometery, J.Sci. Instr. 40, 193 (April).

Kal inkina, I.N., Resistance of carbon thermometers as a function of temperature, Instr. Exp. Tech. No. 3, 580 (Nov.)

Kaufman, A.B., Bonded-wire temperature sensors, Instr. Control Systems 36, 103 (May).

Knobler, C.M., W.I. Honeywell, and C.J. Pings, Thermal and hydrostatic behaviour of miniature platinum resistance elements, Rev. Sci. Instr. 34, 1437 (Dec.).

Kozhukh, V. Ya, Selecting the value of a thermistor for remote measurements of temprature, Measurement Techniques No. 6, 477 (Nov.).

Mcknight, G.P., Res istors for precise temperature measurements, Electron. Ind. 22, $97(\mathrm{Ju} \mid \mathrm{y})$.

Mikhailov, N.N., and A. Ya. Govor, Leaded brass resistance thermometers for measuring low temperatures, Cryogenics 3 205 (Dec.); Instr. Exp. Tech. No.2, 402 ( Nov. $v^{\prime}$ )

Misek, K., and J. Polak, Measurement of temperature of thin metallic wires, cesk. Casopis Fys. 13, 87.

Nalle, D.H., Re Cording small temperature changes, Measurement and Control 2, 363

( Sept.).

orlova, M.P., D.N. Astrov, and L.A. Medvedeva, Indium resistance Thermometers for temperatures in the $3.4-300^{\circ} \mathrm{K}$ range, Instr. Exp. Tech. No. 2, 342 (Nov.).

Priestley, P.T., A thermistor thermometer with digital display, J. Sci. Instr. 40, 505 (oct.).

Riddle, J.F., Temperature measurements beIow $1000^{\circ} \mathrm{K}$, NASA Measurement of Thermal Radiation Properties of Solids $1963 \mathrm{p}$. 11; N64-10939.

Saburi, $0 .$, and $R$. Wakino, Processing techniques and applications of positive temperature coefficient thermistors, IEEE Trans. CP-10, 53 (June).

Sachse, H.B., Measurement of low temperatures with semiconductor resistance thermometers, Z. Angew. Phys. 15, 4 (Jan.).

Sapoff, M., and R.N. Oppenhe im, Theory and application of self-heated thermistors, Proc. IEEE 51, 1292 (Oct.).

Scagnetti, M. $\overrightarrow{S .}$, and J.Crabol, Fast-response platinum film temperature probes, Rech. Aerospatiale No. 97, 23 (Nov.-Dec.).

Scheppner, E., Resistance bulb time constants, AD-409337.

Srivastava, K.C., and J. Singh, Apparatus for measuring temperature in a settling concrete block and controlling it adiabatically, Indian J. Technol. 1, 6 (Jan.).

Terris, D., Platinum resistance Fhermometer circuit with 5 volts output, U.S. At. Energy Comm. Rept. NAA-SR-Memo-8073 IJan. 15): NSA N-20283.

vakalov, I.A., Infl sence of ultra-sound on electrical conductivity of thermoresistors, $A D-412211$.

Vanik, M.C. et al, Reproducible thermistor refinement program, AD-407792.

Voronel, A.V., and V.V. Shchekochikhina, Miniature platinum resistance thermometer, Instr. Exp. Tech. No.2, 364 (Nov.).

Wienke, H.J., P.S. Myers, and O.A. Uyehara, A resistance thermometer for engine compression temperatures, S.A.E. J.71, 104 ( Ju|y).

Corrections for use in low temperature platinum resistance thermometry, Nat 1. Bur. Std. (U.S.) Tech. News Bull.47, 101 (june).

Wafer thermistors provide the route to high precision in resistor manufacture, R \& D No. 19, 51 (Mar.).

\section{4}

Alieva, F.Z., A method of measurng temperature with a platinum resistance thermometer, Air Force Systems Command, Wright Patterson AFB, Ohio, Foreign Technology Division FTD-TT-64-83/1\&4; AD-601561; N64-25451.

Alieva, F.Z., New platinum resistance thermometer for precision measurements of high temperatures, Measurement Techniques No. 6,487 (Dec.). 
Ambrok, G.S., Method of calibrating thermal flow detectors, Measurement Techniques No. 11, 918 (April).

Barber, C.R., International Comparison of platinum resistance thermometers 5167 , R13 and $N 109$ in ten laboratories (Measurement of the interval $0-100^{\circ}$ of the practical international scale of temperaturel, Comite Consultatif Thermometrie Comite Intern. Poids Mesures, 6e, Sevres, France 1962, 64 (Publ. 1964).

Bardila, P.l. $\overline{\text { et al }}$, New platinum resistance thermometer, Measurement Techniques No. 5, 389 (Nov.).

Batha, H.O., and P.E. Carroll, Unicrystalline silicon carbide thermistor, IEEE Trans. CP-11, 129 (June).

Berry, R.J., Choice of resistance thermometer for the region $10-90^{\circ} \mathrm{K}$, Comite Consultatif Thermometrie, Comite Intern. Poids Mesures, 6e, Sevres, France 1962, 125 ( $P$ Publ. 1964).

Black, W.C. Jr., et al, Speer Carbon resistors as thermometers for use below $1{ }^{\circ} \mathrm{K}$, Rev. Sci. Instr. 35, 587 (May).

Boel, M., and B. Erickso $\bar{n}$, A correlation study of a thermistor thermometer, Polytechnic Inst. of Brooklyn PIBAL-696 (May); AD-601656; N54-30589.

Bogdan, L., High temperature thin film resistance thermometers for heat transfer measurement, NASA Contract Rept. CR-26 (1964); AD-414970; N64-17983.

Bogdan, L., Measurement of radiative heat transfer with thin film resistance thermometers NASA Contract Rept. CR-27(1964).

Bulychev, V.S., Thermistor for temperature meter with stabilized supply, Measurement Techniques No. 8, 673 (Feb.).

Chao, J.L., and V.A. Sandborn, A resistance thermometer for transient temperature measurements, AD-600346.

Chappell, R.W., and A. Moilliet, A sensitive resistance thermometer with fast response for use in the sea, Pacific Naval Lab., Esquimalt, British Columbia PNL TM64-3 (May 1964); AD- 443817.

Davis, W.T., Engine temperature indicator, Electronics World 71, 36 (April).

Dupre, A., et al, The use of graphite thermometers in heat conducting experiments below $1^{\circ} \mathrm{K}$, Cryogenics 4,354 (Dec.).

El Agib, A.A.R., The pair ratio me thod of measuring small temperature difference, J. Sci. Instr. 41, 592 (Oct.).

Evans, J.P., and $\overline{G . W}$. Burns, Stability of a platinum resistance thermometer a $\dagger$ high temperatures, Comite Consultatif Thermometrie, Comite Intern. Poids Mesures, 6e, Sevres, France 1962, (Publ. $1964)$.

Fluke, G.L., Winsco platinum resistance temperature transducer-Model 2610-2, AD439778.

Goldwater, F.J., Linearization of resistance thermometer output, J. Sci. Instr. 41, 46 ( Jan.).

Hartuni an, R.A., and R.L. Varwig, A correction to thin-film heat transfer measurements, AD-606036.
Jessop, A.M., A lead compensated thermistor probe, J. Sci. Instr. 4i, 503 (Aug.).

Kaganov, M.A., Precision of differential thermistor measuring circuits, Measurement Techniques No. 3, 231 (Oct.).

Kaganov, M.G., and I.S. Lisker, Inertia of electric resistance thermometers, Inzh. Fiz. Zh. 7, 28 (April).

Kalinkina, T.N., Temperature dependence of the resistance of carbon thermometers, Cryogenics 4, 327 loct.l.

Karbe, Yu.V., Semiconductor surface thermometer, Instr. Construct No. 7, 27 (July).

Kirsa, $v_{.1}$., Method of selecting identical semiconductor thermistors from a batch, Instr. Construct. No. 5, 26 (May).

Kozhukh, V. Ya., The accuracy of temperature measurement with semiconductor resistors, Instr. Construct. No. 3, 10 (Mar.).

LaForce, R.C., S.F. Ravitz, and W.B. Kendall, Device for the precise measurement of small temperature changes, Rev. Sci. Instr. 35; 729 (June).

Langlands, R.C., A stable copper resistance thermometer for field use, J.Sci. Instr. 41,478 (July).

London, G.E., An apparatus for measuring rapidly changing temperatures, WrightPatterson AFB, onio, FTD-TT-64-82/1,2\&4; AD- 601508 .

Manche, E.P., and B. Carroll, Temperature measurement in thermogravimetry, Rev. Sci. Instr. 35, 1486 (Nov.).

Meservey, R.H., Fuel plateres istance thermometer, U.S. At. Energy Comm. Rept. IDO-16965 (March).

Mishchenko, K.P., and V.P. Tungutsov, New method for the calibration of semiconductor resistance thermometers in the determination of the heat capacity of pure Iiquids and solutions, Zh. Prikl. Khim. $37,1243$.

Nakaya, S., and H. Uchiyama, Thermometry of high temperatures with the aid of a platinum resistance thermometer, Comite Consultatif Thermometrie, Comite Intern. Poids Mesures, 6e, Sevres, France 1962, 57 (Publ. 1964).

Novopavlovski i, V.S., Errors in the measurement of surface temperature with the resistance thermometer, Inzh. - Fiz. Zhur. 7, 52 (May).

oreshkin, P.T. et al, Thermistors for measuring the surface temperatures of bodies, Ind. Lab. 30, 296 (Sept.).

or lova, M.P. et al, Germanium resistance thermometer for low temperatures, Inst. Exp. Tech. No. 1, 253 (Sept.).

orlova, M.P., D.N. Astrov, and L.A. Medvedeva, Indium resistance thermometer for the temperature range 3.4 to $300^{\circ} \mathrm{K}$, Cryotenics 4, 95 (April).

Pearson, $\bar{P} \cdot H_{.}, A n$ investigation into the response and corrections to a thermistor and a platinum wire resistance thermometer for temperature measurement in the upper a tmosphere, N64-22493.

Quarmby, A., Transient response of wire resistance thermometers, J.Roy. Aeronaut. soc. 68, 696 (oct.). 
Ruskin, J.M., Thermistors as temperature transducers, Data Systems Eng. 19, 24 (Feb.).

Seuf, G., Temperature measurement with semiconductor diodes, ExptI. Tech. Physik. 12,70 .

stanishevskiy, V.N., Use of thermistors for measurement of temperature, N6515513.

Tebo, A.R., Precise measurement of atmospheric temperatures, Army Signal Res. and Development Agency, Fort Monmouth, N.J., USAELDR-TR-2405; AD-430573; N6420854.

Tsien, H.C., Piston zone temperature measurement, Instr. Control Systems 37, 103 (May).

van Dijk, H., Results obtained from measurements on platinum resistance thermometers at the thermometry section of the Kamerlingh Onnes Laboratorium, Leiden, Physica 30, 1498 (Aug.).

vautier, C., and $A$. Colambani, Thin film platinum resistance thermometers, Compte Rend. 258, 4706.

Zaitsev, A.M., Miniature low-inertia platinum resistance thermometer, Instr.

Exp. Tech. No. 1, 250 (Sept.).

Zsombor-Murray, P.J., A heat transfer probe for use in a high temperature gas, AD-435096.

Platinum $\mathrm{fi}$ ims as temperature probes, Plati num metals Rev. 8,146 loct.).

\section{5}

Boel, M., and B. Erickson, Correlation study of a thermistor thermometer, Rev. Sci. Instr. 36, 904 (July).

Chevako, R.J., Thermistor bibliography, Proc. IEEE 53, 175 (Feb.).

Clark, G.Q., and J.G. McCoy, Upper A tmospheric temperature sensing using the head thermistor, N65-33645.

Coor, T., and L. Szmauz, Digital thermometer, Instr. Control Systems 38, 125 (May).

Cunsolo, S. et al, Interpolation and extrapolation of carbon resistance thermometer calibration data in the liquid helium II region, Cryogenics 5, 168.

George, J.T., and F.D. Demarco, ML-419 thermistor P.E.M. final engineering report, Jan. 1, 1963-Aug. 31, 1964, Bendix Corp., Baltimore, Md., Friez Instr. Div., AD-608963; N65-26306.

Gerber, R., F. Vilim, and K. Zaveta, Measurement of low temperature with a carbon thermometer, Cesk. Casopis Fys. 15, 340 (Czech).

Hales, J.L., and E.F.G. Herington, A new method for the computation of temperature in platinum resistance thermometry, J. Sci. Instr. 42, 203 (April).

Hardy, D., Temperature sensing resistor environment test, Texas Instr. Inc. Rept. No. 5849-E; AD-460242.

Janicke, J.M., Direct-reading platinum thermometer, Instr. Control Systems 38 , 129 (May).

Jones, E.W., Calibration techniques for thermistors, Instr. Control Systems 38, 123 (May).

Lakh, V.I., and V.A. Kochan, Overheating of platinum resistance thermometers by a measuring current, Teplofizika Vysokikh Temperatur 3, 661 (July).

Nechaev, G.K.', Semiconductor thermistors in automation Wright-Patterson AFB, Ohio, Foreign Tech. Div. Rept. No. FTD-MT-64210; AD-618048; N65-31893.

or lova, M.P. et al, Germanium resistance thermometer for low temperatures, cryogenics 5, 165 .

Pharo, L.C.C. Some characteristics of the VECO $32 \mathrm{~A} 8$ thermistor operating in a se If heated condition, Rev. Sci. Instr. 36, 211 (Feb.)

Priestly, P.T., Multiple thermistor indicator for thermometric analysis, J. Sci. Instr. 42, 35 ( Jan.).

Sapoff, M., and R.M. Oppenheim, A blanket approach to a linear thermistor network part 1. The method, Electron. Design 13,20 (Mar.).

Sapoff, M., and R.M. Oppenheim, A blanket approach to a linear thermistor network. Part 2. Examples, Electron. Design 13, 32 (April).

Schneider, D.B., The thermistor thermometer, Instr. Control Systems 38, 119 (May).

Seginer, A., A. Cohen, and J. Rom, Calibration of thin film resistance thermometers for heat flux measurements in a shock tube, Israel J. Tech. 3, 25 (Feb.).

Sychev, $V_{\cdot V} V_{.}$, and N.l. Görbunova, Accuracy of temperature measurement by means of the standard platinum resistance thermometer, Teplofizika Vysokikh Temperatur 3, 632(July).

Toenshoff, D.A., Bird-cage resistance thermometer, Engelhard Inds. Tech. Bull. 5, 127.

Resistor, Thermal (Thermistor) Kearfo $\bar{f} t$ Div. General Precision Inc., Little Falls, N.J., Rept. No. 603-006; AD-463 509 .

Thin $\mathrm{f}$ ilm thermistor temperature sensor. Final report, Metrophysics Inc., Santa Barbara, Calif., AD-472737.

\section{Radiation Devices}

1960

Babushkin, V.V., Apparatus for measuring a high-temperature gas stream at high pressure, Tr. Inst. Kom. Standartov Mer i Izmerit. Priborov pri Sov. Min. SSR 42, 26.

\section{1}

Beattie, J.R., Measurement of the temperature of transparent materials, Acta Imeko 4, 210.

\section{2}

Beer, J.M., and I.J.Claus, The "traversing" method of radiation measurement in l uminous flames, J. I nst. Fuel 35, 437.

Burns, E.A., and R.J.P. Lyon, Errors in the measurement of the temperature of the moon, Nature 196, 463 (Nov.).

Casselton, R.E. W. et al, Black-body radiation from partially enclosed cavities, 
J. Inst. Metals 91, 408.

Faizullov, F.S., Pyrometric investigation of the state of air, nitrogen and argon behind a shock wave, Tr. Fiz. Inst., Akad. Nauk SSSR 18, 105.

Grien, H.R., Plasma spectroscopy, Ionization Phenomena in Gases, Vol. 11 , North Holland Publishing Co.. Amsterdam (1962) p. 1857 .

kean, L., A contribution to the theory of schlieren sensitivity and quantitative evaluation, Aeron. Systems Div., WrightPatterson AFB, Ohio, ASD-TDR-62-924 (Dec.).

Kocho, V.S., V.I.Grankovskii, and V.G. Antosyak, Measurement of gas temperature with a radiation pyrometer, Ind. Lab. 28, 219 (Aug.).

Kroepelin, H., Temperature determination in arcs in hydrocarbon atmospheres, lonization Phenomena in Gases, Vol. II, Nor th-Holland Publishing Co., Amsterdam (1962) p. 1830.

Kudroyavtsev, E.M. et al, Pyrometric investigation of the state of a gas behind a reflected shock wave, Tr. Fiz. Inst., Akad, Nauk SSSR 18, 159.

Lovejoy, D.R., Detection Timits in radiation and optical pyrometer, J. Opt. Soc. Am. 52, 1387 (Dec.).

Maleev, E.M., and D.S. Ermakov, single beam two-frequency pyrometer for measuring flame temperatures, Optics and Spectroscopy 13, 339 (Oct.).

Reeves, E.M., and W.H. Parkinson, Spectral energy distribution and brightness temperatures in continuous flash sources, Ionization Phenomena in Gases, Vol. I, North-Holland Publishing Co., Amsterdam (1962) p. 1017.

Shaw, V.G., Two color pyrometry in the metals industry, Proc. Instr. Soc. Am. 17, Paper No. 58.3.62.

Smith, W.M., and J.L. Frank, Low temperature infrared thermometer, Proc. Instr. Soc. Am. 17, Paper No. 21.4.62.

Sobelev, N. N. et al, A spectroscopic investigation of the state of gases behind a shock wave, Ionization Phenomena in Gases, Vol. II, North-Holland Públishing Co., Amsterdam (1962) p. 2122.

Volk-Levanovits, M.V., Measurement of temperature of a mercury arc by the method of Bartels, Inzh. Fiz. Zh. 5, 87 (Aug.).

\section{3}

Adhav, R.S., and J.G. Kemp, Infrared radiometer, J.Sci. Instr. 40, 26 (Jan.).

Bates, R.L., and W.L. Eisenman, Improved black radiation detector, Naval Ordnance Lab., Corona, Calif., NOLC Rept. 594, Photodetector Series 60 (Dec. 15, 1963); $A D-426778$.

Bruckner, R., Spectrometeric measurements of temperatures above $3500^{\circ} \mathrm{C}$ and determination of temperature distribution in a plasma burner at atmospheric pressure, Ber. Dtsch. Keram. Ges. 40, 603.

Casselton, R.E.W., G. Erez, and T.J. Quinn, Black-body radiation from par- tially enclosed cavities, J. Inst. Metals (G.B.) 91 pt 12,408 (Aug.).

Clark, R.G., Monitoring surface temperatures of irradiated fuel elements, U.S. At. Energy Comm. Rept. HW-SA-3036 (May 6).

Drawin, H.W., Spectroscopic temperature and density measurement of plasmas in the absence of thermodynamic equilibrium, Z. Phys. 172, 429.

Dreyfus, M. $\cdot$.' Spectral variation of blackbody radiation, Appl. optics 2, 1113 (Nov.).

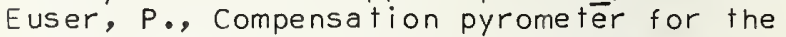
measurement of surface temperatures of moving parts independent of the surface emissivity, Instr. Pract. 17, 487 (May).

Fairbairn, A.R., Temperature measurements of $\mathrm{C}_{2}$ and $\mathrm{CN}$ radicals generated in a shock tube, II Detonation, Proc. Roy. Soc. (London) A276, 513.

Fateeva, N.S. et al, An optical method of determining the melting temperature of graphite as a function of pressure up to 40,000 atm, Soviet Physics-Doklady 8, 904 (Mar.).

Frock, H.N., and W.T. Shreve, A new automatic balancing optical pyrometer, Proc. instr. Soc. Am. Paper No. 29.5.63.

Gaydon, A.G., I.R. Hurle, and G.H. Kimbell, Temperature measurements of shock waves and detonations by spectrum-line reversal, IV Development of detonation, Proc. Roy. Soc. (London) A273, 241 (May 21).

Gilardini, A., Microwave determination of after glow temperatures and electron col1 ision parameters in nitrogen and oxygen, $A D=418360$.

Golub, L.M., and E.S. Shpigelman, Rationalizing the calibration method of reference telescopic radiation pryometers, Measurement Techniques No. 4, 317 (Oct.).

Gordov, A.N., Noncontact methods of measuring the true temperature of heated bodies, High Temperature 1,128 (July-Aug.).

Gordov, A.N., Simplífication of the method for calibrating and testing color pyrometers, Measurement Techniques No. 1, 41 $(\mathrm{Aug} \cdot)$.

Goryachev, B.A., Photoelectric pyrometer, Ind. Lab. 28, 1202 (Nar.).

Greenshields, D.H., Spectrometric measurements of gas temperatures in ac-heated jets and tunnels, NASA Tech. Note D-1960 (oct.).

loselson, G.L., Methods for automatic compensation of the emission coefficient in measuring the plasma temperature with respect to radio-frequency thermal radiation, High Temperature 1, 391(Nov.-Dec.). Kandyba, $v . v$. , Measureme $\bar{\dagger}$ of temperature in flames, gas flows, and plasmas from spectral line intensities, High Temperature 1, 386 (Nov.-Dec.).

Kelsal1, D., An automatic emissivity compensated radiation pyrometer, J. Sci. Instr. 40, 1 ( Jan.).

Kirenkov, T.I., Effective wave length of a photoelectric spectral pyrometer, Measurement Techniques No.6, 474 (Nov.).

Kogan, A.V., A method of reducing the error of a disappearing $f$ ilament pyrometer, High Temperature, 1,273 (Sept.-Oct.). 
Kozyrev, B.P., Basic problems of radiation pyrometry of slightly heated or cooled objects, Inzh.-Fiz. Zh. $6,9$.

Kusch, H.J., Development of methods for quantitative spectroscopic temperature determination of plasmas, keel U. Inst. Exp. Phys. $\mathrm{N}-21786$.

Land, $T_{\text {. }}$, and R. Barber, Some recent developments in radiation pyrometry, Trans Soc. Instr. Technol. 15, 1 (Mar.).

Lapina, E.A., An infrared pyrometer for the determination of spectral coefficients of black body radiation of some types of oxide cathodes, Tr. Inst. Gos. Kom. Standartov, Mer i Izmeritel' $n$. Priborov SSSR No. 71, 153.

Lapp, M., and L.P. Harris, Influence of alkali-vapor atmospheres on pyrometrically determined temperatures; cesium and potassium, J. Appl. Phys. 34, 3622 (Dec.).

Laughin, R.D., Needle temperature measurement by infrared pyrometry, Textile Res. J. 33,35 ( Jan.).

Lehman, W.J. Jr., Black body radiance-temperature conversion table, Aberdeen Prooving Ground Rept. DPS 1059 (Aug.); $\mathrm{AD}-417811$.

Magdeburg, $H_{.}$, The measurement of temperature distribution on the surface of temperature radiatiors, $Z$. Instrumentenk. 71,22 (Jan.).

Mak, W.H., Sodium I ine reversal temperature measurements in shock-tube flows, Toronto $U$. Inst. Aerophysics (Canada) UTIA-TN-66 (May); AD-419307; N63-19188.

MCGregor, W.K., Spectroscopic measurements in plasma, Northwestern $U$. and Am. Inst. Aeronautics and Astronautics, Biennial Gas Dynamics Symposium, 5 th, PhysicsChemical Diagnostics of Plasmas, Evanston, III., (Aug. 14-16); Nor thwestern University Press (1964), p. 143.

Meyer, J.H., and J.P. Puckett, A rotary kiln shell temperature scanner, Elec. Eng. 82, 618 (Oct.).

Miller, J.T., Revised course in industrial instrument technology. Chapter 10. Radiation pattern thermometers on pyrometers, Instr. Pract. 18, 153 (Feb.).

Moffitt, G., Study of a temperature measuring system for the $1000^{\circ} \mathrm{C}$ to $2500^{\circ} \mathrm{C}$ range, Wright-Patterson AFB, ohio, Flight Control Lab. ASD-TR-61-487; AD274794; N63-16853.

Nadaud, L., and M. Gicquel, optical measurement of high temperatures, NASA Sci. and Tech. Aerospace Rept. N-15329.

Ohm, E.A., and W.W. Snell, A radiometer for a space communications receiver, Bell System Tech. J.42, 2047 (Sept.).

Pekker, I.I., E.I. Fand $\overrightarrow{e e v}$, and V.E. Shuksheenov, Radiation temperature transducer for moving surfaces, I zv. vyss. ucheb. Zaved. Priborostr. 6, 145.

peloquin, R., and $M$. We iss, $\bar{A}$ irborne instrument for precision measurement of sea surface temperature using infrared radiation emitted by the sea, Marine Sci. Instr. 2, 61 .

Penzias, $\bar{G} . J .$, and R.H. Tourin, Measure- ment of temperature ingaseous detonations by monochromatic radiation pyrometry, ARL 6385 (May); AD-418763; N63-15058.

Percy, J.W., Basic oxygen steelmaking-continuous bath temperature measurement, Proc. Instr. Soc. Am. 18, Paper 21.2.63.

Peuteman, A., New pyrome ter using a lead sulfide cell. Surface measurement of temperatures over $100^{\circ}$, Rev. Gen. Thermique $2,417$.

Poskache $\bar{i}, A . A$. Radiation measurement of temperatures below $800^{\circ}$, Tsvetn. Metal. 36 , No. 9, 76.

Porter, R.A., Significance of radiative sky temperature in the determination of the apparent temperatures of materials, Rand corp. The application of precise microwave technology to satellite meteorology, A Symposium (Aug. 1963), p. 157.

Powling, J., and W.A.W. Smith, The surface temperature of burning ammonium perchlorate, Combust. Flame 7, 269.

Ramsey, P.W. et aT, Infrared temperature sensing systems for automatic fusion welding, Welding J., Res. Suppl.42, 3375 (Aug.).

Rowen, T.R., Black body radiation tables, Army Missile Command, Huntsville, Ala. TN-AMSMI-RNR-1-63: AD-418979; N64-13856.

Ryan, L.R., H.J. Babrov, and R.H. Tourin, Infrared spectra and temperatures of plasma jets: spectrometric and spectroradiometric measurement of plasma jet temperature distributions, Wright-Patterson AFB, ohio, Aeronautical Research Labs., ARL63-35 (Feb.); AD-404867; N63-16512.

Schwarz, F., Infrared detectors, ElectroTechnol. (N.Y.) 72, 116 (Nov.).

Semikin, 1.D., A radiation thermometer, Foreign Tech. Div., Air Systems Command, Wright-Patterson AFB, ohio, FTO-TT-63-64; $A D-409749$; N64-21943.

Simmons, F.S., Spectroscopic pyrometry of gases, flames and plasmas, ISA Trans. 2, 168 (April).

Sorgenicht, W., Radiometer based on the Gerlach principle and radiometer probes in industrial use, Elektrowarme 21, 45 (Jan.).

Taft, W.C., K.C. Stotz, and E.H. Holt, A gated radiometer for plasma after-glow study, IEEE Trans. on Instrumentation and Measurement $\mid M-12,90$ (Sept.).

Takata, S.., on the procedures and the accuracy of brightness matching in optical pyrometry, Natl. Res. Lab. of Metrology (Japan) Bull. No.7, 7 (Nov.).

Tourin, R.H., Recent developments in gas pyrometry by spectroscopy, AFOSR J 1483 ; $A D-427539$.

Tourin, R.H., L.R. Ryan, and H.J. Babrov, Some spectrometric and spectroradiometric measurements of temperature in plasma jets, N63-23486.

Tsuchiya, S., Instantaneous temperature measurement by a modified sodium-0 I ine reversal method, Nippon Kagaku Zasshi 84 , 300.

Walker, M., J. Roschen, and E. Schlegel, An infrared scanning technique for determination of temperature profiles in microcircuits, Trans. Inst. Elect. Electron. 
Engrs. ED-10, 263 (July).

wildey, R.L., Bolometric-correction and effective temperature scale, Nature 199, 988.

Woolvet, G.A., and J.M. Alexander, Radiation pyrometer for temperature measurement in the hot extrusion of aluminum, J. Inst. Metals 92, 430.

Adaptable radiation pyrometer, Engineer 216,781 (Nov.).

A pyrometer with characteristics independent of emissivity, Control ㄱ, 135 (sept.).

NBS photoelectric pyrometer increases accuracy in temperature measurement, Ind. Heating 30, 660 (April).

Plasma temperature in fusion research, J. Franklin Inst. 276, 270 (Sept.).

Radiometer measures temperatures to $2500^{\circ}$ C, Electron. Design 11, 78 (May).

Test equipment for high temperature studies; Optical pyrometer, Engineering 196, 93 .

\section{4}

Allen, R.A., Nonequilibrium shock front rotational, vibrational and electronic temperature measurement, NASA Contract Rept. 58673; N64-28885.

Alvares, N.J., Measurement of the temperature of the thermally irradiated surface of alpha-cellulose, AD-600768; N64-229 66.

Anufrier, A.A., and L.V. Leskov, optical pyrometry of nonuniform I ight sources, Optika i Spektroskopiya 16, 325 .

Beattie, J.R., The application of radiation pyrometry to glass temperature measurement and control, Proc. Instr. Soc. Am. 19, Paper No. 4 (Feb. 1).

Bernard, B., Determining emissivity, Inst. Control Systems 37, 87 (May).

Boberskii, G.A., Instrument for measuring spectral black-body radiation factors, Measurement Techniques No. 8, 675 (Feb.).

Bowen, T.R., Blackbody radiation tables, $A D-418979$.

Breqev, L.E., Spectroscopy of a supersonic plasma. Il Exitation temperature,

Arnold Eng. Develop. Center AEDC-TDR-64196 (Sept.); AD-447735; N64-31069.

Brodi, G., A.E. Abbott, and D. McCright, Evaluation of infrared radiation pyrometer for measuring reme $1 t$ pour temperatures, U.S. At. Energy Comm. Rept. NLCO890 .

Broussaud, G., and P. Fombonne, The application of Hertzian radiometry for measuring the temperature of the atmosphere, J. Inst. of Navigation 17, 418 (oct.).

Buchele, D.R., Nonlinear-averaging errors in radiation pyrometry, NASA Tech. Note D-2406 (Aug.).

Buchele, D.R., Radiometer-pyrometer for analys is of gaseous combustion products, NASA Tech. Note D-2405; N54-27092.

Burns, J., Research on effects of arc fluctuations on spectroscopically determined temperatures in arc plasmas,
N6 4- 14777 .

Burton, J.T.A., and J.A. Hicks, Detonation emissivities and temperatures in some $1 \mathrm{i}$ quid explosives, Nature 202, 758 (May 23).

Cammerer, J.S., F.C. Cammerer, and G. Fischer, Measurement of surface temperatures and of thermal radiation of large industrial equipment of uneven temperature, Brennstoff-Warme-Kraft 16, 120 (Mar.).

Caulton, G.K., Ratio pyrometer ignores surface variations, Control Eng. 11, 111 (Nov.).

Chr istenson, R.W.S., Environmental errors in use of the airborne infrared radiation thermometer to measure sea-surface temperature, AD-601473: N64-27622.

Combs, H.C., Meteorological applications of infrared radiometry, AD-425911; N6419406.

Doering, $H_{.}$, and $P$. Shahinian, Brightness and two-color pyrometry applied to the electron beam furnace, Naval Research Lab., Wash., D.C., NRL-6062 AD-602292; N64-26914.

Duchon, C.E., Estimates of the infrared radiation temperature correction for cyI indrical temperature sensors, J. Appl. Met. 3, 327 (June).

Esser, F., Radiation pyrometer with a germanium diode as receiver, Neue Hutte $\underline{9}$, 612 (oct.).

Filippov, L.P., N.A. Tuqareva, and L.I. Markina, Methods for determining small pulsations of high temperature and their application to determining metal heat capacities, Inzh. Fiz. Zh. 7, 3 (June).

Finkelshtein, V.E., Precise determination of effective wavelengths of spectro-pyrometers, Measurement Techniques No. 1 , 43 ( July).

Fusse II, W.B., and J.B. Schutt, Temperature of a gray body most closely fitting the solar extra terrestrial spectrum, NASA Tech. Note D-1845.

Gallagher, G., and A. Lemay, Temperature measurements of the near wake generated by hypervelocity bodies, N64-29423.

Hooker, W.J., Preliminary hypervelocity wake brightness temperature measurements, $A D-434999 ; N 64-20139$.

Houston, J.M., and P.K. Dederick, Pyrometer correction due to Dimer absorption, AD430855; N64-16625.

Izakov, M.N., Measuring the temperature of the atmosphere with the aid of satelliteborne instruments, NASA-TT-F-8569.

Kamada, 0 ., Method of measuring target temperature in a solar furnace, Appl. Optics 3. 1397 (Dec.).

kañdyba, $v . v$. , The method and instrument for measuring temperatures of flames, gas flows and plasmas, Acta Imeko 2, 359; NSA $19-46734$.

Kanzler, R.J., An instrument for air temperature measurement using infrared emission of $\mathrm{CO}_{2}$, Bull. Am. Meteorol. Soc. 45, 48.

Kennedy, R.H., Infrared temperature measurement and its application to textile finishing operations, Am. Dyestuff Reporter 53, 56 (Jan. 20). 
Kirenkov, 1.1., Particular features in the development of radiation pyrometry, Measurement Techniques, No. 4, 330 (Nov.).

Kohler, W., and R. Fischer, Temperature measurement by dispersion filters, optik 21, 624 (Nov.).

Laramore, G.E., and D.M. Johnson, A method for determining the effective emitting temperature of a radiating body, Naval Ammunition Depot, Crane, Ind., Research and Development Dept. Rept. RDTR-40 (Aug. 3); AD-604015; N65-10466.

Lieneweg, F., and K. Menge, A two-color automatic pyrometer, Mesures 29, 67 (Mar.).

Magison, E.C., The "whys" of radiation pyrometry, Instrumentation, 17, 19.

Meredith, R. et al, Superheterodyne radiometers for short millimeter wavelengths, Electronics Record 1964, 241 (Feb.).

Mikelson, W., Comparing pyrometer methods for hot strip applications, ISA J.11, 61 (Sept.).

Montgomery, P.W., The detection of turbine wheel temperatures by infrared radiation instrumentation, AD-426917.

Muller, G.0., Contactless temperature measurement with the aid of semiconductor filters, Acta Imeko 1964, 383 Paper No. 23-DDR-233.

Muntz, E.P., and S.J. Abel, The direct measurement of static temperature in shock tunnel flows, AD-436700; N64-245 86.

Murray, B.C., and R.L. Wildey, Surface temperature variations during the lunar night time, N64-20608.

Nadaud, L., and M. Gicquel, Optical high temperature measurement, AGARD ograph No. 68, 281 (1962), Publ. 1964 (France).

Napier, D.H. et al, Temperature measurement in a chemical shock tube by sodium line reversal and $C_{2}$ reversal me thods, A|AA J. 2, 1136.

Okayama, S., Photoelectric optical pyrometer, Tokyo Kogyo Daigaku Gakuko No. 28,1 .

overington, I., and D.J. Williams, Colour densitometry applied to temperature measurement, R \& D No. 30, 38 (Feb.).

Parkinson, W.H., and E.M. Reeves, Design and construction of a new shock tube and experimental measurement of temperatures and oscillator strengths, $A D-4335$ 47; N64-22226.

Paul, F.W., Temperature measurements with an optical pyrometer under adverse conditions, Appl. Optics 3, 297 (Feb.).

Paul, M.C., and P.E. Obe $\overline{r g}$, Modified pyrometer temperature measurement technique, Rev. Sci. Instr. 35, 1078 (Aug.).

Penzias, G.J., R.H. Tour $\overline{i n}$, and S.A. Dolin, Infrared techniques for air temperature measurements in a hypersonic wind tunnel, AD-608983.

Platunov, E.S., and V.8. Fedorov, Use of photographic pyrometry in thermo-physical studies, Teplofiz. Vysokikh Temperatur, Akad. Nauk SSSR $\underline{2}, 628$.

Reeves, E.M., and W.H. Părkinson, Temperature measurement for shock heated pow- dered solids, AO- 433550 .

Reynolds, P.M., A review of multicolor pyrometry for temperature be 1 ow $1500^{\circ} \mathrm{C}$, Brit.J.Appl. Phys. 15, 579 (May).

Richard, B. et al, Measurement of temperature by Hertzian radiometry, Mesures 29, 85 (sept.).

Roberts, A.S., and W.H. Bennett, Plasma temperature measurement for the hollow cathode discharge, J. Appl. Phys. 35 , 3434 (Dec.).

Robinson, D., Heavy particle temperature measurements in a nitrogen plasma by a spectroscopic method, J. Quantitative spectroscopy 4, 335; AD-440101.

Roth, J., Measured temperatures of strong shock waves in argon, J. Appl. Phys. 35 , 1429 (May).

Schofield, D., Effect of laminar boundary layer development on spectrum-line reversal temperature measurement: dispersion line profile, N64-14237.

Shcherbina, D.M., Temperature measurement in solar furnaces, High Temperature 2 , 84 ( Jan.-Feb.).

Soltyk, V.Ya., and V.G. Tishchenko, Pyrometer for remote reading of temperatures (exchange of experience), Ind. Lab. 30 , 1593 (Oct.).

Surh, M.T., and M.G. Whybra, Theoretical studies of a radiation balance, NASA Tech. Note D-2246.

Svet, D.Ya., and T.N. Zavarza, Selection and rational utilization of the spectral sensitivity of photocel is in bichromatic pyrometry, Measurement Techniques No.2, 107 (Aug.).

Tingwaldt, $C_{\text {. }}$, and $\mathrm{J}$. Schley, Two new optical methods for the laboratory determination of surface temperatures of soI ids, Acta Imeko 1964, 353 Paper No. 23DBR- 152 .

Weiss, M., High temperature ultraviolet radiometer, Instr. Control Systems 37 , 95 (May).

Wells, A., and R.H. Kennett, Temperature measurements on a plasma jet, Aeronautical Research Council (G.B.) ARC-CP-756; N65- 10563.

Wilson, J., Discrepencies between theoretical and experimental values of temperature behind a shock wave, Aeronautical Research Council (G.B.) ARC-CP-712: AD407106; N64-18156.

Wormser, E.M., Radiation thermometer with in-l ine blackbody reference, Instr. Control Systems 37, 101 (Dec.).

Emissivity-compensated radiation pyrometer, Instr. Pract. 18, 291 (Mar.).

Radiation pyrometer, prod. Eng . 35, 94(Apr. 271 .

\section{5}

Bakhir, L.P., optical pyrometry of ronuniform sources of radiation, Zh. Prikl. Spektroskopii, Akad. Nauk Belorussk. SSR $2,279$.

Earber, R., and J.0. CresswelI, An evaluation of the accuracy of radiation pyrometers in a rolling mill, proc. 15th 
NatI. Conf. Instr. Iron Steel Ind. 15, paper No. 12 .

Berty, M., Spectrographic measurement of the temperature of a hydrogen plasma jet by the Stark effect, J.Phys. 26, 469 ( Aug.).

Bivans, E.W., Scanning radiation pyrometer, Instr. Control Systems 38, 115 $(J u \mid y)$.

Burley, B.W., Radiation pyrometers to measure the temperature of small objects, Instr. Eng. (G.B.) 4, 33 (April).

Eppig, H.J., E.C. Magison, and D.F. Wood, High speed radiation pyrometer for glass temperature measurement, Glass Ind. 46, 457 (Aug.).

Exton, R.J., A variable exposure photographic pyrometer, ISA Trans. 4,365 (Oct.).

Ferriso, C.C., and C.B. Ludwig, An infrared band ratio technique for temperature determinations of hot gases, Appl. Optics 4, 47 ( Jan.).

GaTley, J., M. Rouannet, and G. Urbain, New photoelectric pyrometer for industrial applications, Engr. Dig. (London) 26, 91 (May).

Greig, J.R., The sodium D-I ine reversal method of temperature measurement in ionized flame gases, Brit.J. Appl. Phys. 16, 957.

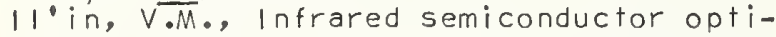
cal pyrometer, Measurement Techniques No. 3, 250 (Aug.).

Kogan, A.V., Optical systems of pyrometers for measuring the temperature of small bodies, Teplofizika Vysokikh Temperatur 3, 747 (sept.).

ko Ftenstette, J.P., Fast response optical pyrometer, ISA Trans. 4 , 270 (July).

krakow, B., Determination of hot-gas temperature profiles from infrared emission and absorption spectra, A|AA J. 3, 1359 $(J u \mid y)$.

Lauver, M.R., J.L. Hall, and F.E. Belles, Shock tube gas temperature measurements by infrared monochromatic radiation pyrometry, NASA Tech. Note D-2955 (Aug.); N65-30899.

Lieneweg, F., Temperature measurement-radiation pyrometer, Arch. Tech. Messen. No. 359, 285 (Dec.).

Lord, J.S., Brightness pyrometry, Instr. Control Systems 38, 109 (Feb.).

Molchanov, V.M., Use of an optical method for measuring temperature differences, Instr. Exp. Tech. No. 1, 165 (Aug.).

Montgomery, P.W., and R.L. Lowery, Turbojet temperature by IR pyrometry, ISA J. 12, 61 (April).

Morgan, J.P., Radiant energy measurement, Instr. Control Systems 38, 127 (July).

Nodwe II, R.A., and J.C. Irwin, A method of determining the reversal temperatures in an excited gas, Can. J. Phys. 43, $1182(\mathrm{Ju} \mid \mathrm{y})$.

Reed, T.B., and J.T. Roddy, optical pyrometer measurement of $r$. f power, Rev. Sci. Instr. 36, 620 (May).

Reingold, L., Theoretical study of the colour temperature and the real tempera- ture of a body radiating in the visible spectrum, C.R. Acad. Sci. (France) 260, 1111 ( Jan. 25).

Reingold, L., Experimental determination of relative emissive monochromatic powers and true temperatures of radiating bodies in the visible and near infrared range, Compte Rend. 261, 71 .

Sadykov, B.S., Temperature dependence of the radiating power of metals, High Temperature 3, 352 (May-June).

Suckewer, S., Spectral measurements of temperature in the plasmatron, High Temperature 3, 178 (Mar.-April).

Svet, D.Ya., Comparison of classical methods of pyrometry for real bodies with a continuous emission spectrum, High Temperature 3, 407 (May-June).

Tourin, R.H., and B. Krakow, Applicability of infrared emission and absorption spectra to determination of hot gas temperature profiles, Appl. Optics 4, 237 (Feb.).

Verch, J., Analys is of q tical-pyrometrical temperature measurements, optik 19, 640 (May); NASA-TT-F-9359; N65-23794.

Wright, M.A., Some spectroscopic methods of gas temperature measurement in the range $3000^{\circ}$ to $10,000^{\circ} \mathrm{K}$, Brit. Coal Util. Res. Assoc. Monthly Bull. 29, 137.

Yamamoto, $N$. et al, Effective utilization of radiation and two-color pyrometers, J. Metals 17, 718 (July).

Young, F.L., Use of infrared instrumentation for detection of jet engine turbine wheel temperature, N65-18398.

Young, L.A., I nfrared temperature measurement of the laminar wake of a hypersonic sphere, AIAA J. 3, 610 (April).

\section{Expansion Devices}

1958

Roshwarf, F., and J. Steinberg, Variable sensitivity gas thermometer for use at low temperatures, Probl. Low Temp. Phys. Thermodyn., Proc. Meeting Comm. I, Intern. Inst. Refrig., Delft, Neth. 1958, 117 .

\section{9}

Glagolev, Yu. A., Distillation of al cohol in a minimum temperature thermometer, $\mathrm{Tr}$. Nauchn.-Issled. Inst. Gidrometioval, Priborostronie 1959, No. 7, 105.

\section{.1962}

Folsom, T.R., R.A. Schwartz, and F.D. Jennings, Scale errors on oceanographic mercurial thermometers, Deep-Sea Research 9 , 219.

Hale, C.E., Gas-filled thermometer for thermocouple calibration, U.K. At. Energy Authority TRG, Rept. 261 R (1962).

Jucheim, P., Attainable control precision of adjustable contact glass thermometers, Glass Instr. Tech. 6, 322 .

Tulin, V.A., A field precision thermostat using mercury contact thermometers, Bull. Acad. Sci. USSR, Geophys. Ser. (8), 677 
(Nov.).

\section{3}

Foster, R.B., Complete Immersion testing of liquid-in-glass thermometers, Proc. Instr. Soc. Am. 18, Paper No. 57-1-63.

Miller, J.T., The $\overline{r e v i s e d ~ c o u r s e ~ i n ~ i n-~}$ dustrial technology. Non-electrical thermometers, Instr. Pract 17, 1323 (Dec.).

Moser, H., J. Otto, and W. Thomas, Gas thermometric measurements at high temperatures. III Determination of the thermodynamic temperatures of fixed Points between $4191065^{\circ}, Z$. Phys. 175,327 .

\section{4}

Holten, D.C., Static and dynamic behaviour of helium-gas thermometers below $77^{\circ} \mathrm{K}$, Advances in Cryogenic Engineering 9, 406; Proc. of the Cryogenic Engineerering Conf., University of Colorado and the National Bureau of Standards, Boulder, Colo., Aug. 19-21, 1963, Ed. by K.D. Timmerhaus, New York, Plenum Press, 1964 U.S. At. Energy Comm. Rept. UCRL-7327, April 16, 1963.

orlova, M.P., and D.N. Astrov, vapor pressure of a helium thermometer for realizing the $T_{58}$ scale, Comite Consultatif Thermometrie, Comite Intern. Poids Mesures, 6e, Sevres, France 1962, 176 (Publ. 1964).

Pamely-Evans, 0.G., Capsule and bulb fluid expansion instruments, Mech. World 144, 415 (Oct.).

Pemberton, L.H., Fur ther consideration of emergent column correction in mercury thermometry, J.Sci. Instr. 41, 234 (April).

1965

Anderson, R.L., and L.A. Guildner, National Bureau of Standards gas thermometer; Constant volume valve, Rev. Sci. Instr. 36,615 (May).

Hagen, E.W., Dynamic gas thermometry, Oak Ridge National Lab., Tenn. ORNL-P-1068; NSA 19-20277.

Hanak, B., Pressure thermometers with nitrogen filling, Jemna Mechanika a optika 10, 54 (Feb.).

Hanak, B., Pressure thermometers with nitrogen filling, Jemna Mechanika a optika 10, 82 (Mar.).

Hanak, B., Characteristics, artificial aging, and quality of nitrogen thermometers, Jemna Mechanika a Optika 10, 209 ( July).

Lieneweg, F., Temperature measurement. Expansion thermometers, Arch. Tech. Messen No. 357, 237 (Oct.).

Moser, H., Gas thermometry at higher temperatures, Metrologia 1, 68 (April).

Swindells, J.F., CalibraFion and use of I iquid-in-glass thermometers, NatI. Bur. Std. (U.S.), Monograph 90 (Feb. 12).
Sychev, I.A., Certain properties of 1iquid manometric thermometers, Measurement Techniques No. 7,627 (july).

\section{Aspirated Devices}

1962

Temme, G., A three-vent probe for measuring flow field pressure and temperature, Wiss. Ges. Luft-u. Raumfahrt, Cologne (W. Germany), Proc. of the joint meeting of the Comm. on Air-Breathing Engines and the Subcomm. on Aerodynamic Measuring Techniques, July 16, 1962, Aachen p. 26; N63-20183.

1963

Kahnwald, H., Development of a rew suction pyrometer for the measurement of higher gas temperatures, Arch. Eisenhutten. 34, $673\left(\operatorname{sep} \dagger_{\text {.) }}\right.$.

\section{5}

Forster, S., A pneumatic apparatus for measurement of high and rapidly changing gas temperatures, Arch. Tech. Messen No. 349, R13 (Feb.).

\section{Other Methods, Descriptive Articles}

\section{8}

van Itterbeek, A. et al, Temperature measurements with an acoustic thermometer, Probl. Low Temp. Phys. Thermodyn., Proc. Meeting Comm. I Intern. Inst. Refrig., Delft, Neth. 1958, 137 .

\section{0}

Taylor, J.W., Residual temperatures of shocked copper, U.S. At. Energy Comm. Rept. LADC-573.

\section{1}

Ato, Y., R. Huzimura, and M. Oishi, A study on radioactive self luminous compounds. Il on the application of radioactive selfI uminous compounds, Proc. Japan Conf. Radio-lsotopes, 4 th, 607 (1961); NSA 1729965 .

Hock, R., Modern electrical temperature measuring device, Chem. Rundschau 14, 528.

\section{2}

Becker, F., and W. Walisch, Precision thermostat with optical control thermometer and controlled Peltier cooling, Z. Physik. Chem. (Frankfurt) 34, 369.

Cataland, G., and H.H. Plumb, Absolute temperatures determined from measurements of the velocity of sound in helium gas, Proc. Advisory Comm. on Thermometry to the Intern. Bur. of Weights and Measures, 6 th Session p. 175 (Sept. 26-27, 1962); Proc. Intern. Conf. Low Temp. Phys. 8 th, London 
1962, 439 (Publ. 1963); Low Temperature Physics, Butterworth's, Wash., D.C. (1963).

Cohen, B.G., Gallium arsenide diode used as low-temperature thermometer, Bell Lab. Record 40, 421 (Dec.).

Forster, S., A pneumatic pyrometer technique-description and applications, wiss. Ges. Luft-u. Raumfahrt, Cologne (W. Germanyl, Proc. of the joing meeting of the Comm. on Air-Breathing Engines and the Subcomm. on Aerodynamic Measuring Techniques (July 6, 1962). Aachen p. 11 .

Leroux, J.P., and M. Poncin, Determination of the temperature of surfaces from $0^{\circ}$ to $400^{\circ}$ by means of photoluminescent emmissions of thin layers, Publ. Sci. Tech Min. Air (France) Notes Tech. No. 119.

Plotkin, E.R., and E.J. Molchanov, use of temperature indicating paints for measuring the temperatures of machine parts Ind. Lab. 28, 214 (Aug.).

Savateev, $A \cdot \bar{V} \cdot$, Compensated thermal noise thermometer, Measurement Techniques No. 2, 114 (July).

Shekhovtsov, A.F., Pneumatic contact device for measuring the temperature of pistons in working engines, Measurement Techniques No. 5, 381 (Nov.).

Solovev, V.I., and A.D. Brodski i, Apparatus for measuring a temperature by means of nuclear quadrupole resonance, Instr. Exp. Tech. No. 2, 332 (Nov.).

Thorne, E.A., The measurement of high temperatures by the determination of the velocity of sound waves in materials, Acoustics Congress, Copenhagen, 1962, Paper P23.

Thureau, P., Measurement of surface temperatures by photoluminescence, Journees Intern. Transmission Chaleur, Paris, 1961,2 , 865 (1962).

vernotte, P.V., Device for measurement of a quantity of heat at ordinary temperatures, Compte Rend. 255, 2914.

Electroacoustic thermometer having a frequency output, Instr. Exp. Tech. No.2, 408 (Nov.).

Mechanical thermometers, Measurement and Control 1, 530 (Dec.).

\section{3}

Bouchard, F., and $P$. Thureau, on a new development in measuring temperatures by photoluminescence, Compte Rend. 256, 87 ( Jan.).

Brodskii, A.D., An electro-acoustic gas thermometer for use in low temperatures, Feinwerk Tech. 67, 299 (Aug.).

Brodskii, A.D., and $V_{\text {.l }}$. Solovev, Reproduction of the temperature scale reference points by quadrupole nuclear resonance, Measurement Techniques No. 9, 763 (April).

Chabbal, R., M. Clement, and R. Geller, Measurement of the temperature in a $P$ I G reflex pulse discharge using a Faboy-Perot interferometer, Nucl. Instr. and Methods, 23, 325 (June).

Cohen, B.G., W. B. Snow, and A.R. Tretola, G
FaAs $p-n$ junction diodes for wide range thermometry, Rev. Sci. Instr. 34, 1091 (oct.).

Dimick, R.C., and G.J. Trezek, Photodiode as a sensitive temperature probe, Rev. Sci. Instr. 34, 981 (Sept.).

Flynn, T.M., H. Hinnak, and D.E. Newell, An improved cyrogenic thermometer, Advan. Cyrog. Eng. 8, 334 .

Fragnaud, F., Application in convection of temperature measurement by luminescence methods, Ministeve de l'air (France) Sci. et Tech. No. 400 (Nov.).

Haas, F.C., An evaporative film colorimetric enthalpy probe, AD-404619.

Howard, D.R., A photographic technique for the measurement of transient high temperatures, Engineer 215, 475 (Mar. 15).

Kundra, K.D., and R. Potshad, Microwave crystals as thermometers in low temperature range, Current Sci. 32, 302 (July).

Levine, D., Unresolved $f$ ine structure of the nitric oxide gamma $0-0$ band for the determination of temperature, N63-14492.

Libby, H.L., The measurement of metal temperature by an electromagnetic induction method, U.S. At. Energy Comm. Rept. HW79621 (Aug. 12, 1963); N64-15834.

Montgomery, H., and G.P. Pells, Errors in helium vapour thermometry, Brit. J. Appl. Phys. 14, 525 (Aug.).

Morozov, $\bar{V} . A .$, and L.S. Tyufyakin, measuring the equivalent temperature of pulsetype noise radiation, Measurement Techniques No. 4, $320(\mathrm{OCt}$.$) .$

Pallett, J.E., Electric thermometer, Electron. Eng. 35, 313 (May).

Pearson, P.H.O., Measurement of atmospheric density, temperature and pressure at Woomera on 29 th March, 1962 by the falling shere method, Res. Weapons Establishment (Australia) Tech. Note SAD-121 (May 1963); N63-19997.

Quneshi, M.H., and F.A. Farqui, Low-temperature pyrometer cones, Pakistan J. Sci. Res. 15, 100.

Richardson, P.D., A swinging thermometer, Am. J. Phys. 31, 395 (May).

Rothert, I.L., and N.P. Udalov, Semiconductor diode as a temperature pick up, Automatika i Telemekhanika 24, 696 (May).

Shepard, G.G., The use of the junction diode as a low temperature thermometer, ohio State Univ. Research Foundation, Antenna Lab. Columbus, Rept. 1083-22 (Jan. 1963); AD-402415; N63-18324.

Smith, P.L. Jr., Limitations on the accuracy of sonic thermometers, Midwest Research Inst., Kansas City, Mo., Rept. AFCRL 63687 (June 1, 1963); AD-412479.

Smith, W.L., and W.J. Spencer, Quartz crystal thermometer for measuring temperature deviations in the $10^{-3}$ to $10^{-6}{ }^{\circ} \mathrm{C}$ range Rev. Sci. Instr. 34, 268 (March).

Solovev, $V .1 .$, and $\bar{A} \cdot D$. Brodski,$A n$ apparatus for measuring temperature by nuclear Quadrupole resonance, Cryogenics 3, 201 (Dec.).

Willkie, D., and S.A. Fisher, Measurement of temperature by Mach-Zender interferometry, Chartered Mech. Engr. 10, 612. 
Gallium-arsenide diode used as low temperature thermometer, Instr. Pract. 17, 37 (Jan.).

ocean thermometer uses ultrasonics, Electron. Design 11, 18 (May).

Ultrasonics takes the ocean's temperature, Elect. Eng. 82, 422 (June).

Ultrasonic thermometer for low temperature determinations, J. Franklin Inst. 275, 56 ( Jan.).

UItrasonic thermometer measures to 0.05 o F, Electronics 36, 77 (April).

\section{4}

Abel, W.R., A.C. Anderson, and J.C. WheatIy, Temperature measuremerits using smal I quantities of cerium magnesium nitrate, Rev. Sci. Instr. 35, 444 (April): U.S. At. Energy Comm. Rept. TID 19533.

Betts, D.S. et al, A susceptibility thermometer for use at very low temperatures J. Sci. Instr.41, 515 (Aug.).

Chognot, M., Method of measuring surface temperatures using the temperature sensitivity of luminescence, Int. J. Heat Mass Transfer, 7, 577 (May).

Court, G.R., and $J$. Sayers, An experimental study of the use of a Langmuir probe to measure electron temperatures and densities in after glows, J.Sci. Instr. 41, 462 ( Ju|y).

Crorini, L., and S. Sartori, Thermal roise and absolute temperature, Recerca Scientifica 4, 155 (March).

Doherty, $\bar{D} . D .$, Temperature measurements in hot gases by thermal neutron scattering, NSA - 26157 .

Fogelson, I.B., Tmperature measurement by means of germanium triodes, Instr. Exp. Tech. No. 1, 248 (Sept.).

Giedt, W.H., and J.T. Chambers, A dual element transducer for measuring high gas temperatures, ASME Winter Annual Meeting, New York, N.Y., Nov. 29-Dec. 4, 1964, Paper 64- WA/HT-45.

Govelik, L.S., and I.B. Fogelson, Tests for measuring temperature by the application of triode thermal detecting units, Instr. Construct. No. 4, 31(Apr.)

Hammond, D.L., C.A. Adams, and P. Schmidt, A linear quartz cystal temperature sensing element, Proc. Instr. Soc. Am. 19, Paper No. 11 (Feb. 3).

Khan, S.A., and P.S. Kohatkar, I nstrument for measuring small temperature variations using thermocaps, Res. Ind. (New Delhi) 9, 296 (oct.).

Larson, G.S., R.N. Lawson, and L.C. Lynnworth, Upper atmospheric sonic thermometry, Proc. Instr. Soc. Am. 19, Paper No. 19 (Jan. 5).

Lee, R.D., Some results and problems of the standardization of the photoelectric pyrometer of the National Bureau of Standards in 1961, Comite Consultatif Thermometrie, Comite Intern. Poids Mesures, 6e, Sevres, France 1962, 79 (Published 1964).

Lezberg, E.A., and D.R. Buchele, Some optical techniques for temperature and concentration measurements of combustion in supersonic streams, NASA Tech. NoteD- 2441 .

Libby, H.L., The measurement of metal temperature by an electromagnetic induction method, U.S. At. Energy Comm. Rept. HWSA-3035 (May 3); NSA N-20282.

olsen, W.D., and H.J. Leinbach, Applicability of dual-path sound propagation measurements to temperature determination over a six-mile path, Army Electronics Research and Development Activity, White Sands, Missile Range, N. Mex., ERDA-112: AD-432009: N64-17438.

Pertsovskiy, G.A., Determination of the bath temperature in the electroslag process by the calorimetric method, N64-11920.

Peterson, J.W., and K.D. McWatters, The measurement of upper-air density and temperature by two radar-tracked falling spheres, N64-17831.

Shaffstall, E.L., A measurement of the roise temperature of a shock- induced plasma at 420 MCPS and 690 MPCS, AD-427067.

Terao, K., Flame temperature measuremen $\dagger$ using the double probe method, Japan J. Appl. Phys. 3, 169 (March).

Terao, K., Electron temperature in a flame front, Japan J.Appl. Phys. 3, 486.

Uo, K.A., Measurement of the perpendicular temperature of the C-stellarator plasma by the diamagnetic coil, N64-21735.

Weder, E., An ultrasonic thermometer for low temperatures, Kal tekchnik 16, 398 (Dec.).

Willkie, D., and S.A. Fisher, Measurement of temperature by Mach-Zender interferometry, Proc. Inst. Mech. Engrs. (London) 178,461 .

Acoustical thermometer establishes provisional low-temperature scale, Nat. Bur. std. (U.S.) Tech. News Bull.48, 189 (Nov.).

Colour strip thermometer, Engineer 217, 447 (March 6).

\section{5}

Bernert, R.E., Cryogenic temperature gage, Chem. Eng. 72, 140 ( July).

Bos, L., Probe for the measurement of gas compositions and temperature in the fusion zone of a cupola furnace, Metalen $\underline{20}, 79$.

CaTvet, E., and C. Guillard, Microcalorimeter equipped with semiconductor thermoelements, Compte Rend. 260 (Groupe 7), 525 .

Carnevale, E.H., L.C. Lynnworth, and G.S. Larson, High temperature measuring device. Final report, Parameters Inc., Wal tham, Mass., NASA-CR- 54339 (Feb. 1); N65-24568.

Cheng, D.Yu., and P.L. Blackshear Jr., Factors influencing the performance of a fast response, transpiration cooled, high temperature probe, Am. Inst. of Aeronautics, Preprint No. 65-359: NSA 19-44204.

Fogel'son, 1.B., Measuring temperature wi th germanium transisor thermoelements, Measurement Techniques No. 12, 1053 (May).

Fogel'son, 1.B., Measuring temperature with silicon transistors, Instr. Exp. Tech. No. 4, 915 (Feb.) 
Fogel'son, I.B., Operation of the transistor as a thermosensitive element, N6510150 .

Giedt, W.H., A dual element transducer for measuring high gas-stream temperatures, Trans. ASME, Ser C (J. Heat Transfer) 87,397 (Aug.).

Hammond, D.L. et al, A linear, quartz crystal, temperature sensing element, ISA Trans. 4, 349 (Oct.).

Hammond, $\bar{D} \cdot L .$, and $A$. Benjaminson, Linear quartz thermometer, Instr. Control Systems 38, 115 (oct.).

Joyce, D.E., Capacitance temperature sensor, General Electric Co., Cincinnati, onio, GEMP-89 (June 25); N65-26336; NSA 19-36748.

Kerman, M., Investigation of microstate electronics, gallium arsenide as cyrogenic temperature sensors, Final report, Simmonds Precision Products Inc., Tarrytown, N.Y., Rept. No. 11029 (July): AD$469914 \mathrm{~L}$.

Lang, S.B., and F. Steckel, Study of the ultrasensitive pyroelectric thermometer, Rev. Sci. Instr. 36, 1817 (Dec.).

Lovborg, L., A linear temperature to frequency convertor, J. Sci. Instr. 42, 611 ( $\mathrm{Aug} \cdot$ ).

Malozemov, $V_{\cdot} V_{.}$, and I.A. Turchin, Determination of temperature fields with the interferometer, Inzh. Fiz. Zh. (USSR) 8, 182 (Feb.).

oleson, S., An improved sonic anemometerthermometer, AD-619996; N65-34557.

Planer, G.V., and P.J. Evison, Temperature sensing capacitors, Electron. Components 6 , 217 (March).

Plumb, H.H., and G. Catal and, Absolute temperature scale from $4^{\circ} \mathrm{K}$ to $20^{\circ} \mathrm{K}$ determined from measurements with an acoustical thermometer, J. Res. NatI. Bur. Std. (U.S.) 69A, 375 ( July).

Reeves, D., M.E. Inglis and L. A irey, The fluid oscillator as a temperature sensor, Fluid Logic and Amplification Conference, Paper No. D1, (Sept. 1965); N65-36403.

Reisman, E., and P.M. Sutton, Measurement of air temperature distributions with the schlieren interferometer, Appl. opt. 4, 144 ( Jan.).

Robins, P.J., Temperature measurements by ultrasonics, Ind. Electron. 3, 482 (oct.).

Sargeant, D.H., Note on the use of junction diodes as temperature sensors, J. Appl. Meteorology 4, 644 (oct.).

Sato, M., Electrochemical geothermometer; a possible new method of geothermometry with electroconductive minerals, Econ. Geol. 60, 812 (June).

Wheeler, $\bar{E} . E .$, Sensitive suppressed zero thermometer, J. Sci. Instr. 42, 42 ( Jan.).

8. Special Applications, Method Not Soecified in Title

1961

Roessler, F., Temperature measurement of a flame combined with a high-frequency torch, Proc. Intern. Conf. Ionization Phenomena Gases, 5th, Munich, 1961, 1, 842 (Publ. 1962).

\section{2}

Bereznikov, V.V., and G.A. Lavrenter, Thermocouple installation in parts made of polymer material, Ind. Lab. 28, 526(oct.).

Danberg, J.E., The equilibrium temperature probe, a device for measuring temperatures in hypersonic boundary layers, Advances in Hypervelocity Techniques, Plenum Press, N.Y. 1962, p. 693.

Froebel, A.T., on the measurement of temperatures in shock waves, N65-36373.

Hukuo, N., Measurement of temperature in a solar furnace, Nagoya Kogyo Gijutsu Shikensho Hokoku 11, 303.

Michalski, L., Measurement of surface temperature of rotating cylinders, Pomiary, Automat., Kontrola 3 , 407 (Sept.).

Pavia, R.V., and D.H. Edwards, A Precision jet pipe temperature indicator for $\mathrm{flight}$ use, Aeronaut. Res. Lab., Meljourne, Australia ARL/F-33 (Sept.); N63-19903.

Rozenblit, G.B., Measurement of small temperature variations on the surface of soI id bodies, Measurement Techniques No. $2,120(\mathrm{Ju} \mid \mathrm{y})$.

strauss, $W_{.}$, The measurement of high gas temperatures, Australian J. Instr. Technol. 18, 141 (Nov.).

1963

Arai, T., Studies on the air temperature measurement, Army Missile Command, Huntsville, Ala., Redstone Scientific Information Center, RSIC-31 (July 23); N53-19755.

Bahgat, F., Furnace gas temperature evaluation for marine boilers, Naval Eng. J. 75,647 .

Be $\overline{c k}, G$. , and R. Bigot, on the recording of temperature differences between the center and surface of a cylinder of nickel cooled by tempering, Compte Rend. Acad. Sci. 256, 619 (Jan. 14).

Benedict, R.P., High response aerosol probe for sensing gaseous temperature in a twophase two component flow, Trans ASME $(\mathrm{J}$. Eng. Power) 85A, 245.

Benson, J., Gauging $\mathrm{f}$ iber temperatures, Rubber Age 93, 410 (June).

Branger, M., Veil cooling of radial-flow turbines, The Garrett Corp., Air Research Manufacturing Div. Rept. K-500 (oct. 11).

Coombe, R.A., Measuring temperatures in the range $1000^{\circ} \mathrm{C}$ to $5000^{\circ} \mathrm{C}$. Part I, R \& 0 No. 28, 18. (Dec.).

Crabtree, R.I., and G. A. Wheeler, Radiation effects investigation of selected transducers and materials for Nerva program. Volume I, U.S. At. Energy Comm. Rept. FZK-159-1 (April 26).

Critides, L., Instrument measures thread surface temperature, I nd. Eng. Chem. 55, 10 (sept.).

Crook, R.F., Determining the operating temperature of an AC coil, Electro- Technol. 
(N.Y.) 71, 160 (May).

Dudnik, L.A., and E.B. Perchik, Measurement of the grid temperature of an electron tube by change of resistance, Inzh. Fiz. Zh. 5, 110 (Mar-.).

Gee, K.H., Metal temperature and slag analysis improve blast-furnace control, J. Metals 15, 512 (July).

Geil, F.G., and J.H. Thompson, An in situ temperature sensor, Marine Sci. Instr. 2, 35 .

Grāves, F.L., and H.S. Loveless, Convenient measurement of deflaction temperature under load and Vicat softening point, Mater. Res. Std. 3,33 (Jan.).

Grey, J., Sensitivity analysis for the calorimetric probe, Rev. Sci. Instr. 34 , 857 ( $\mathrm{Aug}$. ).

Gutzwiller, W.R., Tool measures piston temperature of Diesels, Abstract SAE J. 71,83 (May).

Headly, J.A., and J. McGeagh, Specimen heating with temperature measurement from $-150^{\circ} \mathrm{C}$ to $2200^{\circ} \mathrm{C}$ inside the EN6 electron microscope, J.Sci. Instr. 40 , $484\left(0 \mathrm{C} \dagger^{\circ}\right)$.

Hudimac, A.A., J.R. Olson, and D.F. Brumley, A mobile instrument of ocean temperature in the thermocline region, Marine Sci. Instr. 2, 49.

Karp, T., Electronic dark room thermometer, Radio Electronics 34,60 (oct.).

Kourim, G., Electrical temperature measuring device for installation where danger of explosions exist, Arch. Tech. Messen. No. 334, 257 (Nov.).

Kudlacik, H.W., and D.M. Willyoung, Local rotor winding temperature measurements for large turbine generator fields, Power Apparatus and Systems No. 64, 687 (Feb.).

Kurzrock, J.W., Selection of surface thermometers for measuring heat $f$ lux, Cornell Aeronaut. Lab., AD-404770; N6318751 .

La Fond, E.C., Towed sea temperature structure profiler, Marine Sci. Instr. 2. 53 .

Lee,,$P$. W. et al, Method for predicting temperatures in continuous hot strip milis, J. Inst. Iron Steel (London) 201, 270.

Leontev, A.K., A simple method for determining the temperature of a heat transfer surface, Inzh. Fiz. Zh. 5, 78(July).

Lubbs, E.K., Device for measuring temperature in a closed rotating flask, J. Chem. Educ. 40, 200.

MacHattie, L.E. Temperature measurement of textile fabrics under intense irradiation, Brit. J. Appl. Phys. 14, 267 (May).

Malin, W., J. Davison, and C. Krollman, Development of a deiced fast response dual element total temperature sensor, AD- 622247 .

Markussen, B.H., How to estimate piston temperature, Abstract: SAE J. 71, 97 (May).

Marshali, G.S., and R.H. Henderson, Recorting temperatures in deep bore holes,
Engineering 196, 540 (Oct. 25).

Masalovich, G.T., Local temperature measurements in forging and stamping, Measurement Techniques No. 11, 935 (June).

McLaren, T.I., J.N. Fox and R.M. Hobson, Double probe measurements of electron temperatures in a shock tube, Nature 198 , 1264 (June 29).

Miers, B.T., and N.J. Beyers, Rocket-sonde wind and temperature measurements be tween 30 and $70 \mathrm{KM}$ for selected stations, Army Electronics Research and Development Activity, White sands Missile Range, N. Mex., Rept. ERDA-70 (Sept.); N63-22783.

Moeller, F., and H. Meyer, Surface temperature measurement, Arch. Tech. Messen. No. 323, 269 (Dec. 1962) No. 324, 1 (Jan. 1963).

Nanigan, J., Temperature measurements and heat transfer calculations in rodset nozzle throats and exit cones, Proc. Instr. Soc. Am. 18 Paper No. 29. 3. 63.

orlova, M.P., and D.N. Astrov, Measurement of remperatures below $10^{\circ} \mathrm{K}$, measurement Techniques No. 8, 669 (Feb.).

Perls, T.A., and J.J. Hartog, Pyroelectric transducers for heat-transfer measurements, ISA Trans. 2, 21 (Jan.).

Petit, $Y_{.}$, and $M$. Dembno, Measurement of surface temperatures of rotating machine elements Mesures Controle Ind.28, 699 (May).

Redstreake, W.N., Sensors promise to close loop on control of molten metal, Iron Age 191,73 (June).

Reid, A.F., Filament temperatures from geometry-independent electron emission junctions, J. Electrochem. Soc. 110, 135 (Feb.).

$\mathrm{Smith}, \mathrm{R} . \mathrm{A}$. , Atmospheric radia Tive temperature measurements, Rand Corp., The Application of Passive Microwave Technology to Satellite Meteorology, A Symposium (Aug. 1963) P. 37; N63-16497.

Tassicker, 0.J., Effect of inductance on the measurement of winding temperature in electrical plant, Proc. Inst. Elec. Engrs. (London) 110, 419 (Feb.).

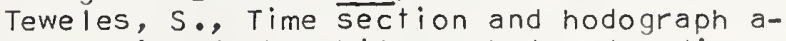
nalys is of Churchill rocket and radiosonde winds and temperatures, Intern. Geophys. Year World Data Center A. Wash., D.C., A Third Compilation of U.S. IGY-IGC Rocket Program Results, (April 1963) p. 72; N63-19679.

Wald, D., Measuring temperature in strong fields, Instr. Control Systems 36, 100 (May).

Zinman, W.G., Temperature measurements in hydrogen-oxygen detonations, $J$. Chem. Phys. 39, 3534. A low-temperature pyrometer Control 6,102 (Feb.).

Evaluation of soil temperature thermometers, Army Electronic Prooving Ground, $j$ For $\dagger$ Huachuca, Ariz., AD-408192.

Generator temperatures monitored by failsafe system, Elec. World 159, 116 (Feb. 25).

Mapping the temperature of the ocean surface, New scientist 18, 723 (July).

measuring surface temperature of subliming solids, R \& D No. 21, 42 (May). 
160 (Oct.).

Pyrometer reads molien iron temperature continuously, Foundry 91, 86 (Nov.).

Surface pyrometer for high speed cylinders, Power and Works Eng. 58, 47 (March).

Temperature measuring screws, Eng. Mater. and Design 6, 239 (April).

Temperature probe for moving sheets, belts and drums, $R$ \& $D$ No. 18, 52 (Feb.).

\section{4}

Benson, R.S., Measurement of transient exhaust temperatures in internal combustion engines, Engineer 217, 377(Feb.)

Boynion, F.P., Chemical $k$ ine $\overline{f i c}$ analys is of rocket-exhaust temperature measurements, AIAA J. 2, 577 .

Cato, G., Measurement of free air properties from on board a large launch vehicle, N64-24906.

Chappel, R.M., Bonding of electrical leads to germanium for ultrahigh-vacuum and high temperature measurements, J. Appl. Phys. 35, 2783 (Sept.).

Chen, F.F., Double-probe method for unstable plasmas, Rev. Sci. Instr. 35, 1208 (Sept.).

Chizhov, A.F., Temperature measurements of the free atmosphere taking into account the recombination of atoms, N6424591 .

Clark, G.Q., and J.G. McCoy, Rocketsonde measurement of stratospheric temperature, Army Electronics Research and Debelopment Activity, White Sands Missile Range, N. Mex., ERDA-24Z: AD-453993; N65-17924.

Clayton, W.H., B.J. Eckelkamp and J.H. Machet ta, $A$ wet and dry bulb temperature measuring system for microemteorological application, Texas A \& M Univ. College Station AFCRL-64-938; AD-610107; N65-18982.

Cowne, R.W., Atmospheric temperature measurement from aircraft, Proc. Inst. Soc. Am. 19, Paper No. 19 (Jan. 4).

Fendly, J.R. Jr. and K.G. Hernquast, Ionization mechanism and electron temperature in cesium arecs, Proc. IEEE 52, 964

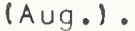

Fischer, W.A., and H.J. Fleischer, Continuous temperature measurement for basic oxygen steelraking, J. Metals 16 , 483 (June).

Grabowsky, W.R., L.Y. Lam, and D.A. Durran, Double shock tube method for simultaneous determination of $\mathrm{h}$ igh pressure and temperature of an enclosed gas, N6416129.

Haas, A., Ambient temperature compensated non-contacting surface thermometer, Acta Imeko 1964, 339 Paper No. 23-HU-105.

Hamilton, R.L., and C.H. Miller, Yarn temperatures attained during cyclic straining and heat transfer properties of yarns, Textile Res. J. 34, 20 (Jan.).

Hvetz, J., J.P. Leroux, and G. Palazy, Contribution to the measurement of surface temperatures, Compte Rend. 259, $2801\left(\mathrm{Oct}_{\text {. }}\right)$.
Kirchhoff, R.H., Calorimetric heating rate probe for maximum response time interval, AlAA J. 2, 966 (May).

Kirk, W.B., Flue gas temperature measurement procedures, ASHRAE J. 6 , 40 (June).

Kordig, J.W., Backside temperätures of an interval insulator in a solid-propellant motor, AIAA J. 2, 1475 (Aug.).

Lapworth, K.C., Temperature measurements in a hypersonic shock tunnel, AGARDograph 1964, 267: AGARD, The high temperature aspects of hypersonic flows (1964) 255.

Lenschaw, D.H., and J.A. Dutton, Surface temperature variations measured from an airplane over several surface types, J. Appl. Meteorol. 3, 65 (Feb.)

Logan, C.A., and R.P. Johnson, Automatic temperature measurement as applied to a cement kiln, Proc. Instr. Soc. Am. 19, Paper No. 4 (Jan. 1).

Lorenz, D., Measurement of the earth's surface temperature from aircraft, N64-24953.

Meieran, S., Temperature sensor for strain gage transducer, Electronics 37, 77 IMay 4).

Merryman, R.G., A study of temperature measurement. Precision in Debye - Scherrer specimens during high temperature $x$-ray diffraction measurement of thermal expansion, N64-21873.

Minzner, R.A., G. Sauermann, and L.R. Peterson, A new method for atmospheric temperature determination, AD-427618.

Newcomb, T.P., Clutch temperatures, Automobile Eng. 54, 154 (April).

Penskii, F.l., Temperature measurements of internal combustion engine pistons, Measurement Techniques No. 7,610 (July).

PowelI, W.B., and T.W. Price, A method for the determination of local heat flux from transient temperature measurements, ISA Trans. 3, 246 ( July).

SterbutzeT, G.A. et al, A probe for the instantaneous measurement of surface temperature, RTD TDR63-4015; AD-431314; N64-21489.

Subbotin, V.l., M. Kh. l bragimov, and $E . V$. Nomofelov, Statistical study of turbulent temperature pulsations in a liquid stream, $\mathrm{High}$ Temperature 2, 59 (Jan.-Feb.).

Tskhai, N.S., A method of determining the $k$ ine tic temperature of a gas Teplofizika Vysokikn Temperatur 2, 294 (March-April).

Whittaker, A.G., and D.C. Barham, Surfacetemperature measurements on burning solids, J. Phys. Chem. 86, 196.

\section{5}

Auskern, A.B., and W.E. Thompson, Temperature indication during hot pressing, Am. Ceram. Soc. Bull. 44, 459.

Ballard, H.N., Rocke Fsonde techniques for the measurement of temperature and wind in the stratosphere, ERDA-269; AD-458308; N65-22478.

Barrett, R.E., and H.R. Hazard, Problems in flue - gas temperature measurements, ASHRAE J. 7,88 (Jan.).

Bates, J.J., Measurement of commutator temperature by a sliding-contact thermometer, 
Proc. Inst. Elec. Eng. 112, 835 (April).

Bernard, B., Flame temperature measurements, Instr. Control Systems 38, 113 (May).

Brunschwig, F.S., G.E. Kock, and J.K. Wilhelm, Thermal sensor design for glide reentry vehicles, NASA Washington Symp. on Thermal Radiation of Solids, N6526911 .

Cox, G.B., Effects of reduced pressures on passive temperature indicators (TempPlatesl, McDonnell Aircraft Corp., St. Lou is, Mo., Rept. No. 051-065.73; AD460040

cutt, R.A., Proportional control steadies cryosurgical probe temperature, Control Eng. 12, 103 (Mar.).

Fateyev, A.V., A device for measuring the temperature of rotating bodies, Priborstronie 8, 26; N65-24155.

Fomin, Yu. Ya., and B.K. Gundorin, Measurement of rapidly changing temperatures of fuel at high pressures, Measurement Techniques 2, 152 (July).

Forgacs, R.L., B.A. Parafin, and E. Eichen, High voltage cathode temperature measurement, Rev. Sci. Instr. 36, 1198 ( $A \cup g$.$) .$

Gallagher, H.P., and B.D. Mallet, Liquid oxygen temperature instrumentation model $D M-18, A D-454062$.

Goldberger, R., Thermal probe speeds environmental testing, Electron. Ind. (Phila.) 24, 114 (May).

Gordov, A.N., Peculiarities of the measurements of temperature under conditions of alternating heat emissions, Foreign Tech. Div., Air Force Systems Command, Wright-Patterson AFB, Ohio, FTD-TT-64-1076; AD-615431.

Gurevich, Ya.B., and A.P. Bashchenko, Measurement of the metal surface temperature in rolling, Measurement Techniques No. 11, 989 (April).

Hall, B.F. Jr., and N.F. Spooner, Temperature measurement in a graphite environment from $1600^{\circ}$ to $2500^{\circ} \mathrm{C}$, ISA Trans. $\underline{4}$, 355 (oct.).

Keglin, B.G., and B.I. Khrapov, Measurement of temperature in a point of the surface during unsteady friction, Ind. Lab. 30, 1197 (Mar.).

Kiselev, V.M., Thermal probes for measuring the density of heat flows, FTO-TT64-1115; $\mathrm{AD}-614949$.

Land, T., Probe pyrometer for glass, Ind. Process Heat 5, 4 (Aug.).

Lieneweg, F., Temperature measurement; contact thermometers Part 1, Arch. Tech. Messen. No. 357, 237 (Oct.).

Lutsker, I. Sh., Device for the remote measurement of the temperature of rotating parts in a closed chamber, Ind. Lab. 31, 465 (Mar.).

Marlatt, W.E., The measurement of the surface temperature of the earth, NASACR-62117; N65-21425.

Mehrishi, J.N., and J.W. Lorimer, Temperature measurement in rotating-cylinder viscometers, J. Sci. Instr. 42, 173

(Mar.).
Merryman, R.G., and C.P. Kempter, Precise temperature measurement in Debye-Scherrer specimens at elevated temperatures, J. Am. Ceram. Soc. 48, 202.

Mikhailov, M.D., Measuring the temperature of flows with a pulsating velocity, Measurement Techniques, No. 5, 419 (May).

Parafin, B.A., and E. Eichen, High vol tage cathode temperature measurement, Rev. Sci. Instr. 36, 1198 (Aug.).

Terrey, D.R., $\bar{A}$ contact pyrometer for the measurement of specimen temperatures on a thermobalance, J.Sci. Instr. 42, 507 $(J \cup \mid y)$.

Watson, G.G., Surface temperature measurement, Design Components Engineering No. 20,32 (nov.).

Weinstein, I., and R.R. Howell, Technique for measuring high-temperature isotherm patterns on aerodynamically heated models with experimental results, NASA-TN-D2769; N65-23162.

\section{Nuclear Applications of Temperature Measurement}

\section{0}

Lampe, D.A., Reactor cone thermal instrumentation, U.S. At. Energy Comm. Rept. TID 18103 .

\section{2}

Brindley, J.H., Experimental calibration of surface attached thermocouples on a $\mathrm{flat}$ plte fuel element, Trans. Am. Nucl. Soc. 5, 478 (Nov.).

Brook, E.J., W.C. Kramer, and R.D. McGowan, $\mathrm{High}$ temperature sensors for BORAX-V boiling fuel rods, U.S. At. Energy Comm. Rept. ANL6636 (Oct.).

Walstedt, R.E., Pulsed nuclear magnetic resonance thermometer, Problems of Low Temperature Physics and Thermodynamics Vol. 3. MacMillan Co., N.Y., 1962, p. 109.

\section{3}

Browning, W.E. Jr., Me thods of measuring temperature in nuclear reactors, Progr. Nucl. Energy. Ser. I $V$, 5, 1 .

Budak, H., Cl35 isotope i $\mathrm{NaClO}_{3}$ as nuclear Q.R. thermometer, Istanbul Univ. Fen. Fak. Mecmuasi, Seri C, 28, 142 (July-oct.).

Conkling, D.R., and T.L. Rasmussen, Thermocouple attachment for tre initial EOCR cone, U.S. At. Energy Comm. Rept. IDO16836 (Feb.).

DuBridge, R.A., In-core instrumentation development program. Detectors for in-core power monitoring, U.S. At. Energy Comm. Rept. GEAP-4222; NSA 30852.

Greenberg, H. J., Clamp on process tube temperature detector for monitoring nuclear reactor operation, Engelhard Inds. Tech. Bull. 4, 101 (Dec.).

Rainey, W.T. Jr., R.L. Bennett, and H.L. Hemphill, Measurement of temperature in reactor environments, U.S. At. Energy Comm. Rept. ONRL-3417. 
Terry, F.D., Effects of transient nuclear radiation on transducers and electrical cables, U.S. At. Energy Comm. Rept. IDO16914 (Nov. 30).

Nerva components irradiation program. Vol. 4, GTR test 7A, General Dynamics Corps., For $t$ Worth, Texas, FZK-170-4; NSA 1914868 .

\section{4}

Babbe, E.L.., Increasing thermocouple reliability for in-pile experiments, Trans. Am. Nucl. Soc. 7, 55 (June).

Babbe, E.L., Development program to increase thermocouple reliability for inpile experiments, U.S. At. Energy Comm. Rept. TID 7597.

Bianchi, G., and S. Moretti, Behaviour of thermocouples under irradiations, Energie Nucleare 11, 426 (Aug.).

Bianchi, G., and L. Matteuzzi, Description of an apparatus for testing of $n$ - gamma irradiated thermocouples, U.S. At. Energy Comm. Rept. RT/IVG(54-1).

Bianchi, G., and L. Matteuzzi, Description of experiment for thermocouple irradiation tests, U.S. At. Energy Comm. Rept. $R T / / N G(54-2)$.

Breen, 8.P., and G. Burnet, Peak heat flux in nucleate boiling heat transfer, U.S. At. Energy Comm. Rept. Is-810; N64-17740.

Briggs, N.H., E.L. Long, and F.R. McQuilkin, Summary of experience with high temperature thermocouples used in the ORNL-GCR program fuel experiments, ORNLP-1055; NSA 19-20401.

Chapin, W.E., and E.N. Wyler, Transducers in nuclear environments, ISA J. 11, 45 (Dec.).

Chappell, E.E. et al, Nerva components irradiation program. Vol. 3, GTR test 13, General Dynamics Corp., Fort Worth, Texas, FZK-184-3; NSA 19-13812.

Dallman, A.C., Mechanical reliability and thermoelectrical stability of noble metal thermocouples at $2600^{\circ} \mathrm{F}$ temperature and dose rates up to $10^{20}$ nvt.

Davoine, F., R. Schley, and M. Villamayor, Les couples thermoelectriques D'alliages tungstene - rhenium, Commissariat a I'Energie Atomique. Centre d'Etudes Nucleaires, Saclay, CEA-R-2481; NSA 199438.

Elliot, M.N., and J.R. Grover, The measurement and control of gas temperature in the Fingal process, AERE-R- 4512 (Dec.): N55-21943.

Fanciullo, S., Thermocouple development for the $1 \mathrm{i}$ thium cooled reactor experiment, U.S. At. Energy Comm. Rept. PWAC422 (Mar. 5).

Hawkins, R.C., Neutron flux monitors and thermocouples for in-core reactor measurements, At. Energy of Canada Ltd., Chalk River, Ontario, AECL-2033.

Hluchan, S.A., Pressure and temperature transducers for high temperature and nuclear radiation environments, U.S. At. Energy Comm. Rept. Conf-658-1.

Krohova, M., and I. Saxl, Radiation sta- bility of thermocouples, U.S. At. Energy Comm. Rept. UJV-987.

McCarty, W.K., Thermocouple evaluation program, U.S. At. Energy Comm. Rept. NAA$\mathrm{SR}-\mathrm{Memo}-9635$.

TalInan, C.R., Cryogenic temperature measurement in a nuclear radiation environment, U.S. At. Energy Comm. Rept. LA-DC6549 .

Walters, C.T., and E.O. Fromm, Automatic reduction of long term irradiation capsule thermocouple data, U.S. At. Energy Comm. Rept. 7697.

Applications of ultra sonic energy: ultrasonic instrumentation for nuclear applications, Bimonthly progress Rept. No. 19, (oct. 1- Nov. 30), Aerojets, Inc., West Chester, Pa. NYO-2910-7 (Dec.); NSA 19-11478.

Periodic calibration of temperature sensing elements - reactor plant portion, U.S. At. Energy Comm. Rept. WAPD-PWR-TE159 .

Reactor instrumentation and control progress Rept. No. 85, General Electric Co., Cincinnati, Ohio GEMP-85 (Nov. 30); NSA-19-10467.

\section{5}

Asphaug, B., Gamma thermometer development at HBWR, U.S. At. Energy Comm. Rept. HPR (Vol. 1) (Sec. 7).

Broks, E.J., Some in-vessel instrumentation programs representative of the United States, Argonne Natl. Lab., I daho Fal Is, Idaho. CONF-640607(Vol. 1) (Paper A-14); NSA $19-24013$.

Carroll, R.M., and P.E. Reagan, In-pile performance of $\mathrm{high}$ temperature thermocouples, Oak Ridge NatI. Labs., Tenn. ORNL-P-1066; NSA 19-18344.

Eubank, H.P., Electron temperature measurements with atomic beams, Princeton Univ., N.J., Plasma Physics Lab., Rept. MATT-276 ( June); N55-10598.

Falk, J., Instrumentation of the Swedish R2 - loop No. 2, Aktiebolaget A tomenergi, Stockholm, Sweden CONF-640607 (Vol. 1 ) (Paper B-3); NSA 19-24168.

Hawk ings, R.C., I n-core instrumentation a $\dagger$ C.R.N.L., At. Energy of Canada Ltd., Chalk River, ontario CONF-640607 (Vol. 1) (Paper A-3); NSA 19-2407.

Kjaerheim, G.K., Central oxide temperature measurements, U.S. At. Energy Comm. Rept. (HPR-35 (Vol. 11) (Sec. 13)).

Kjaerheim, G.K., Measuring fuel rod center temperatures, Euro Nuclear 2,72 (Feb.).

KuhIman, W.C., Evaluation of Fhermal neutron induced errors in the W/W-25 Re thermocouple, AlAA propulsion Joint Special ist Conference, Colorado Springs, Colo., June 14-18, 1965, Paper 65-563.

Lupoli, P., G. Bianchi, and S. Morretti, Behaviour of irradiated thermocouples, experimental investigations, Comitato Nazionale per I'Energia Nucleare, Ispra (Italy) CONF-640607 (Vol. II) (Paper D4): NSA 19-24014.

Morretti, S., Behaviour of irradiated ther- 
mocouples. Theoretical investigations, Comitato Nazionale per $1^{\prime}$ Energia Nucleare, ispra (Italy) CONF-640607 (Vol. 2) (Paper D-5); NSA 19-22657.

Morrison, R.G., Application of miniature intrinsic thermocouples for reactor transient diagnostics, Los Alamos Scientific Lab., N. Mex., LA-3313-MS; N6527629; NSA 19-38236.

Prince, W.R., and W.L. Sibbitt, High temperature reactor core thermocouple experiments, Los Alamos Scientific Lab., N. Mex., LA-3336; N65-29244; NSA 1938237 .

MCQuilkin, F.R., N.H. Briggs, and E.L. Long Jr., Summary of experience with high temperature thermocouples in the ORNL-GCR program, fuel-irradiation experiments, Trans. Am. Nucl. Soc. 8, 69 (May).

Rolstad, E., Thermocouples, cables and tubes for in core instruments at HBWR, U.S. At. Energy Comm. Rept., HPR- 35 (Vol. 2) (Sec. 10).

Stentz, R.H., and R.L. Treinen, Development of nuclear sensors, Final report, General Electric Co., Cincinnati, Ohio, GEMP-90; NSA 19-38091.

Subbotin, V.l. et al, Small scale thermocouples for measuring temperature in the reactor of the first atomic power station, Teploenergetika No. 5, 91 (May).

Walstedt, R.E. et al, Nuclear spin thermometry below $1{ }^{\circ} \mathrm{K}$, Proc. Roy. Soc. (London) 284A, 499.

Component development, Oak Ridge NatI. Lab., Tenn., ORNL - 3812; NSA 19-35772.

High temperature materials and reactor component development programs. Fourth Annual Rept. Vol. 1, Materials, General Electric Co., Cincinnati, Ohio, GEMP334A: NSA 19-24916.

$\mathrm{High}$ temperature materials and reactor component development programs. Vol. 3, Instrumentation and controls, Gen. Elec. Co., Cincinnatti, Ohio, GEMP-334C; NSA 19-25639.

High temperature materials program Progress Rept. No. 43, Part A, Oct. 15-Dec. 15, 1964, General Electric Co., Cincinnati, Ohio, GEMP-43A; N65-30592.

High temperature materials program, Progress Rept. No. 49, Part A, Gen. Elec. Co., Cincinnati, Ohio, GEMP-49A; N6530592 .

Process instrumentation development, Oak Ridge NatI. Lab., Tenn., ORNL-3782; NSA19-42690.

Reactor instrumentation and control. Progress Rept. No. 87, Gen. Elec. Co., Cincinnati, Ohio, GEMP-87; NSA 19-24016.

Reactor instrumentation and control, Progress Rept. No. 88, Gen. Elec. Co., Cincinnati, Ohio, GEMP-88; NSA 19-38090.

\section{Associated Equipment and Testing Procedure}

1961

Houke, H.F., Study of high-current resis- tance testing of grounded shielded Chromel-Alumel thermocouples, AD-459284.

Nordberg, W., and W.G. Stroud, Results of IGY rocket-grenade experiments to measure temperatures and winds above the is land of Guam, J. Geophys. Res. 60, (Feb.); Intern. Geophys. Year Wor Td Data Center A. Washington, D.C. A third compilation of U.S. IGY-IGC Rocket Program Results, April 1963, p.23; N63-19678.

Schlegel, E.S., Apparatus for determining temperature profiles in microstructures, Rev. Sci. Instr. 34, 360 (April).

\section{2}

Bulychev, V.S., Automatic indication of broken thermocouples in potentiometer EPP-09, Measurement Techniques No.2, 125 (July).

Gehrmann, E., and I. Schusta, Method for the determination of the time constant of thermocouples, Wiss Z. Hochsch. Elektrotech. I Imenau. $8,419$.

Lehmann, K., and K. Schme iser, New temperature measuring equipment for rotatable furnaces, Elektrotech. Z. 14B, 462 l Aug. 20).

Pak, V., and Yu. P. Krinskii, Automatic equipment for calibrating platinum platinorhodium thermocouples, Measurement Techniques No. 1, 38 (June).

Rahlfs, P., Testing contact thermometers, Arch. Tech. Messen. No. 323, 279 (Dec.).

\section{3}

Brown, D.L. et al, Instrumentation and recording equipment used in conjunction with the ARL twenty-inch hypersonic wind tunnel, Wright Patterson AFB, Ohio, Aeron Res. Lab., Rept. ARL 63-162 (sept.).

Cameron, G., and R. L. Blanchard, Performance and use of metal freezing-point cells which generate precise temperature, ISA Trans. 2, 224 ( July).

Cox, C.D., and W.D. Edwards, I ce point maintained thermoelectrically and regulated by change of state, Rev. Sci. Instr. 34, 704 (June).

Dengler, C.0., A new mercury freezing point cel1, ISA Trans. 2, 298 (Oct.); Instr. Control Systems $3 \overline{6}, 119$ (Dec.).

Dengler, C.O., A freezing apparatus for the triple point of water cell, Proc. Instr. Soc. Am. 18, Paper No. 57.4.63.

Foord, T. R., R. C. Langlands, and A. J. Binnie, Transformer-ratio bridge network with precise lead compensation and its aplication to the measurement of temperature and temperature difference, Proc. Inst. Elec. Engrs. 110, 1693(Sept.).

Foster, R.B. Jr., An air-bath comparator for I iquid-in-glass thermometers, U.S. At. Energy Comm. Rept. SCTM-21-63 (24) (Feb.).

Hill, J.J., and A.P. Miller, An AC double bridge with inductively coupled ratio arms for precision platinum-res is tance thermometry, Proc. Inst. Elec. Engrs. 110,419 (Feb.).

Isakov, M.N., Measurement of atmospheric 
temperature by means of satel 1 ite-borne equipment, Kosmicheskie issledovaniia, 1, 159 ( July - Aug.).

John, R.E., Temperature distribution and thermal efficiency of low power archeated plasma jets, Brit. J. Appl. Phys. 14,585 (Sept.).

Jones, T.P., The suitability of tungsten strip lamps as secondary standard sources in photoelectric pyrometry, J.Sci. Instr. 40, 101 (March).

Kayander, M.S., Radiator with large sighting coefficient for calibrating radiation pyrometers, Measurement Techniques No. 10, 850 (June).

Margulis, O.M. et al, Refractory insulation for thermal electrodes used for measuring high temperatures, Measurement Techniques No. 6, 480 (Nov.).

McDonough, R., and H.A. Hawthorne, An inexpensive resistance welder for thermocouple fabrication, U.S. At. Energy Comm. Rept. TID 19268.

Meiran, S., Tester checks out thermocouple circuits, Electronics 36, 102 (Mar. 15).

Metzler, A.J., and J.R. $\overline{B r}$ anstetter, Fas $\dagger$ response blackbody furnace for temperatures up to $3000^{\circ} \mathrm{R}$, Rev. Sci. Instr. 34, 1216 (nov.).

Murdock, J.W., C.J. Foltz, and C. Gregory, A practical method of determining response time of thermometers in liquid baths, Trans. ASME (J. Eng. for Power) $85 \mathrm{~A}, 27$.

Pak, V., Yu. P. Krinskii, and I.S. Belyaeva, Simplified equipment for calibrating precious metal thermocouples in a dynamic condition, Measurement Techniques No. 11, 923 (June).

Rotbert, I.L., and N.P. Udalov, Temperature transmitters incorporating semiconductor diodes and transistors, Instr. Construct. No. 10, 1 (Oct.).

Russell, A., An inexpensive thermocouplescanner using gold-plated relays, Control 7, 132 (Sept.).

Sata, T., and R. Kiyoura, studies on the tungsten furnace and its temperature measurement by $W$-WRe thermocouple up to $2700^{\circ} \mathrm{C}$, Tokyo Inst. Technol. Bull. No. 53.

Savage, B., A multipoint thermocouple reference junction, J. Sci. Instr. 40, 45 ( Jan.).

Silverman, L., Reference junctions, Instr. Control Systems 36, 107 (June).

Tao, Li-ten, Automatic potentiometer circuits with temperature compensations for thermocouples, Instr. Construct. No. 8, $9(\mathrm{Aug},)^{\circ}$.

Vanvor, $H_{\text {. }}$, Testing and standardization of apparatus to measure temperatures. Resistance thermometers and thermocouples, Intern. Elektrowaerme - Kongr., 5., Wiesbaden, Ger. 1963, 625.

Voitenko, A.E., F.O. Kuznetsov, and I.S. Model, The use of an IFK-50 lamp as a high-intensity, pulsed standard source, Instr. Exp. Tech. No. 6, 1184 (July).

Weiner, S., and F. Schwartz, Thermopile IR detectors, Space/Aeronautics 40, 95
$\left(A \cup g_{0}\right)$.

A useful temperature duration recorder R\&D No. 18, 42 (Feb.).

Automatic thermocouple comparator, Nat 1. Bur. Std. (U.S.) Tech. News Bull. 47, 82 (May).

\section{4}

As theimer, R.W., and S. Weiner, Solidbacked evaporated thermopile radiation detectors, Appl. Optics 3, 493 (April).

Barber, C.R. et al, A full-radiator lamp designed to replace the tungsten strip lamp as a pyrometric standard, Nature 202, 686 (May 16).

Brouwer, G.P., A highly sensitive recording electronic pyrometer, Philips Res. Rept. 19, 471 (Oct.).

Buynyachenko, G.P., Multi-range potenitometer bridge, N64-13581.

Ebinger, $A_{\text {., }}$ and $G$. Siegfried, Potentiometer for thermoelectric voltages with electronic stabilized auxiliary current source, Z. Instrumentenk. 72, 103 (April).

El Agib, A.A.R., A hydraulic bridge for measuring small temperature difference, J. Sci. Instr. 41, 596 (oct.).

Gelfond, L., Evaluation of the model PRAIC thermocouple reference junction, Rocketdyne, Canoga Park, Calif., Rept. No. TR64-7; AD-470 583 .

Goldberg, J.L., and H.M. King, Automatic switching of sensitive thermocouples, Electron. Eng. 36, 591 (Sept.).

Grote, H.H., Improvement of sensor response by an analog technique, Army Signal Rem search and Development Agency and Lab., Fort Monmouth, N.J. USAELRDL-2445; N6426507; AD-600 141 .

King, J., The design of a temperature-compensated thermocouple reference circuit, $A D-600675$.

Knowlson, P.M., and P.M. Bartle, sealing a stainless-steel-sheated thermocouple into a Magnox end cap, J. Inst. Metals 93,52 (oct.).

Kozhukh, V. Ya., Computation of thermistor bridge circuits for automatic measurements of temperature difference, Measurement Techniques No. 7, 601 (July).

Lancia, F.M., and J.D. McGervey, Apparatus for measurements of Peltier coefficients, Rev. Sci. Instr. 35, 1302 (Oct.).

Levi, L.I., E.A. Chernin, and A.I. Degaltsev, Device for determining the dynamic properties of immersion thermocouples, Ind. Lab. 29, 1674 (June).

Meyer, $H_{.}$, and $E$. Wilde, Thermoelement leads for high vacuum devices and which can be thoroughly heated, Exp. Tech. Physik 12,

Pak, V., and Yu. P. Krinski i, Automatic testing of commercial thermocouples made of non-precious metals, Measurement Techniques No. 5, 391 (Nov.).

Ruff, A.W. Jr., Open-probe thermocouple control of radio-frequency heating, Rev. Sci. Instr. 35, 760 (June).

Schechowzow, A.F., Pneumatic contact device for measuring piston temperature in a running motor, Feinwerk Technik 63 , 
18 ( Jan.)

Schmitz, L.S., Nonl inear analog ne twork to convert surface temperature to heat flux, N64-18176.

Shcherbina, D.M., Application of a Kerr cell for comparing luminous fluxes, Measurement Techniques No. 1, 41 (July).

Shcherbina, D.M., Supplies for standard temperatature lamps from rectifiers, Measurement Techniques No. 8, 620 (Feb.).

Shimanskiy, Yu. N. et al, A device for high-speed recording of small temperature drops, N64-29149.

Skuratov, S.M., and M.N. Goroshko, Simple bridge circuit for measuring the resistance of a platinum resistance thermometer, Measurement Techniques No.2, 104 ( Aug.).

Thomson, J.H., Development of an improved time-temperature integrator, AD- 434147.

Zhinkin, B.N., Electrical oven for testing thermocouples, Measurement Techniques No. 1,45 ( July).

A new temperature measuring apparatus for laboratory purposes, Arch. Tech. Messen. No. 344, 209 (Sept.).

Automatic thermocouple comparator, Instr. Control Systems 37, 91 (May).

Digital thermometer covers wide range, Electronics 37, 113 (May 4).

\section{5}

Boom, G., and $F$. van der Woude, Very stable and simple compensator for thermocouples, Rev. Sci. Instr. 36, 857 (June).

Caldwell, F.R., Temperatures of thermocouple reference junctions in an ice bath, J.Res. NatI. Bur. Std. (U.S.) 69C, 95 (April).

Claggett, T.J., External thermocouple compensation, Instrumentation 18, 24.

Dengler, C.O., Frezing apparatus for the triple-point-of-water cell, Instr. Control Systems 38, 117 (May).

Feldman, C.L., Automatic ice-point thermocouple reference junction, Instr. Control systems 38, 101 (Jan.).

Greenwood, T.L., Thermocouple-continuity monitor, ISA J. 12, 88 (Feb.).

Hobson, D.L., and $\bar{B}$. Cohen, Temperature measuring test set, Ind. Electron. $\overline{3}$, 117 (March).

lchiye, T., and N.B. Plutchak, Calibration and field test of IRT, Lamont Geological Observatory, Pal isades, N.Y. Rept. No. CU-12-65 Nonr-26648; AD-470 136.

Kochan, V.A. et al, Automatic recording instrument for measuring low temperatures, Measurement Techniques No. 1, 52 (June).

Kol'tsov, A.A., and G. Kh. Valeyeva, Analysis of one measuring circuit for automatic electronic potentiometers measuring temperature, N65-24157.

Miksch, E.S., Equilibrium of the ice-water temperature standard, Rev. Sci. Instr. 36, 797 (June).

Pak, V., Bridge method for comparing precious metal thermocouples, Measurement Techniques No. 2, 149 (Feb.).
Perrey, H.E., Amplifier for temperature sensors, ISA J. 12, 67 (Jan.).

Schrenker, H., Automatic, electronic compensators in submerged pyrometric installations, Arch. Tech. Messen. No. 358, R142 (Nov.).

Schwarzer, H., Electrical temperature measurement and equipment, Arch. Tech. Messen. No. 356, 197 (Sept.).

Sereznov, A.N., Me thod for reducing the noise level at the input of an instrumen used in measuring temperature with thermocouples, Measurement Techniques No. 6 , 503 (June).

Sharpe, J., An application of photomultiplier tubes in temperature measurement, Ind. Electron. 3, 471 (oct).

Stansbury, E.E. e $\bar{\dagger}$ al, Modified dauphinee thermocouple comparator circituit for adiabatic calorimetry, Rev. Sci. Instr. 36, 480 (April).

\section{General}

1962

Kirk, F.W., and N.R. Rimboi, I nstrumentation, Am. Tech. Soc., Chicago, 111 .

ohring, G., W. Tang, and $Y$. DeSanto, Theoretical estimates of the average surface temperature on Mars, J. Atmospheric Sci. 19,444 (Nov.).

Slaughter, J.I., and J.L. Margrave, Temperature measurement, Aerospace Corp., Los Angeles, Calif. Rept. No. TDR-169 (324020) $\mathrm{TN}-1$ (oct.); $\mathrm{AD}-298142$.

Temperature of Venus, Instr. Pract. 16, 1494 (Dec.).

\section{3}

Agabohov, S.G., and A. Komarek, Blackness of platinum and platinum-rhodium wires, Inzh. Fiz. Zh. 6, 79.

Ambrok, G.S., A.N. Gordov, and A.G. I vanova, Method of determining the thermal inertia of some types of temperature measuring devices, High Temperature 1, 413 (Nov.Dec.).

Benedict, R.P., Temperature and its measurement, Electro-Technol. (New York) $72,71(\mathrm{Ju} \mid \mathrm{y})$.

Be nedict, R.P., Temperature measurement in moving fluids, Electro-Technol. (New York) 72, 56 (Oct.).

Billing, $\bar{B} . F$. . Thermocouples, a critical survey, Royal Aircraft Establishment, Farnborough, England, RAE-TN-CPM-18 (May); N65-20747.

Bodea, E., Rationalizing the kinetic definition of temperature, Acta Phys. Austriaca 16, 80.

Cook, N.H., and E. Rabinowicz, Physical measurement and analys is, Addison-Wesley Publ ishing Co., Reading, Mass.

Corruccini, R.J., Temperature measurements in cryogenic engineering, Advan. Cryog. Eng. 8, 315 .

Fruchtmān, I., Temperature measurements of hot gas streams AlAA J. 11909 (Aug.).

George, A.L. et al, Converśion formula for 
thermocouples, Instr. Control systems 36,133 ( July).

Gerishenzon, S.S., and K.N. Manuylov, On the rate of detecting temperature gradient changes by measuring instruments, Foreign Tech. Div., Air Force Systems Command, FTD-TT 63 540; AD 415007.

Graziano, E.E., Experimental measurements of velocity and temperature profiles and skin-friction in supersonic turbulent compressible flow: an annotated bibliography, N63-23615.

Hertzfeld, C.M., ed. in chief, Temperature, its measurement and control in science and industry. Volume 3, part 3 , Biology and medicine, J.D. Hardy, ed., Rheinhold Pub. Corp., N.Y.

kostkowski, H.J., and G.W. Burns, Thermocouple and radiation thermometry above $900^{\circ} \mathrm{K}$, NASA Measurement of thermal radiation properties of solids, p. 13.

Kurti, N., Temperatures below $1{ }^{\circ} \mathrm{K}$, Advan. Cryog. Eng. 8, 1 .

Malone, E.W., Surface temperature measurement errors, Trans. Inst. Elect. Electron. Engrs. AS-1 15 (Feb.).

Marcus, H., Present and future requirements for high temperature measurements, NASA Measurement of thermal radiation properties of solids, p. 434.

Sokeland, W.P. e t al, A typical problem in heat transfer: determine the steadystate axial temperature distribution in a conical thermocouple support, Eng. J. (Montreal) 10, No. 2, 42.

Sokeland, W.P. and J.A. Payne, Solution to the previous problem: determine the steady-state axial temperature distribution in a conical thermocouple support, Eng. J. (Montreal) 10, No. 4, 50 .

stimson, H.F., J.F. swindel Is, and R. E. wilson, Temperature scales, thermocouples and resistance thermometers, Am. Inst. Phys. Handb. Second ed. Sec. 4a, pp. 2- 21 .

Stotzek, H., Thermal measurement sys tems and their construction from individual measuring instruments, Arch. Tech. Messen No. 331,181 (Aug.).

Timmerhaus, K.D., Measurement of low temperatures, Cryogenic Engineering, John Wiley \& Sons, N.Y. p. 196.

Some developments in techniques for temperature measurement, Proc. of a Symposium (April 26, 1962) Inst. Mech. Engrs. (London) 1963.

\section{4}

Barber, C.R., Temperature scale measurement techniques for the range 10 to $90^{\circ}$ K, Acta Imeko p. 415, Paper No. 23-UK246.

Barber, C.R., Temperature scale of the National Physical Laboratory in the range $10-90^{\circ} \mathrm{K}$, Comite Consultatif Thermometrie, Comite Intern. Poids Mesures, 6e, Sevres, France 1962, 19 (Pub. 1964).

Barber, C.R., Conference on the measurement of high temperatures, London May 1964, Brit.J.Appl. Phys.15, 1003 (sept.).

Bauer, W., and R. Buschner, Report on measurement of the air temperature with various types of radiation shielding, N6416484.

Bollinger, L.E., Transducers for measurement. Part 3 Temperature from one extreme to the other, ISA J.11,73 (oct.).

Conison, J., Process temperat ure measurement, Instr. Control Systems 37, 141 (June).

Coombe, R.A., Measuring temperatures in the range $1000^{\circ} \mathrm{C}$ to $5000^{\circ} \mathrm{C}$, Part 2 , R\&D No. 29, 14 ( Jan.).

Diamond, J.J. ed., Bibliography on the high temperature chemistry and physics of materials in the condensed state, International Union of Pure and Applied Chemistry 1964, No. 4 (Oct.-Dec.).

Grey, J., Thermodynamic methods of high temperature measurement, ISA Trans. $\underline{4}$, 102 (Apr. - June).

Hall, W.M., The application of temperature rate measurements to the determination of thermal emittance, N64-20604.

Hammond, C.M., and D.L. Burk, A simplified thermal analysis technique for measuring transformation temperatures of steel, Mater. Res. Std. 4, 275 (June).

Hoffman, E.E., Potadssssium corrosion tes $\dagger$ loop development Quarterly Progress Rept. No. 5 (July 15, 1964-Oct.15, 1964) General Electric Co., Cincinnati, Ohio, NASACR-54269; NSA 19-20473.

Holbeche, T.A., and D.A. Spence, A theoretical and experimental investigation of temperature variation behind attenuating shock waves, Proc. Roy. Soc. (London) A279, 111 (May 12).

Hunt, L.B., The early history of the thermocouple, Platinum Metals Rev. 8, 23 $(\mathrm{Jan})$.

I to, T., and T. Morikawa, The methods of the measurement of temperature and electron density of arc plasma, Mitsubishi Denki Giho 38, 8 (Dec.).

Kirenkov, I.1., Basic metrological problems in temperature measurements, Measurement Techniques No. 12, 1009 (June).

Koch, H., Application of temperature measuring methods in flow technology, Arch. Tech. Messen No. 340, 97 (May).

Landensperger, W., and D. Stark, The total optical emissivity of rhenium, rhodium, palladium, and titanium, Z. Physik 180, 178.

Lapworth, K.C., Investigation of the Physical properties of gases at high temperatures, J. Roy. Aeronaut. Soc. 68, 189 (Mar.).

Lehmberg, A.E., Calculation of temperature sensor error introduced by frictional heating, AD- 48866.

Lieneweg, F., Indication delay of thermometers, Arch. Tech. Messen No. 340, R46 (May).

Louis, J.R., and W.E. Hartman, The determination and compensation of temperature sensor transfer functions, ASME Winter Annual Meting, New York, Nov. 29-Dec. 4, Paper 64-WA/AUT-13. 
Miller, J.T., Revised course in industrial instrument technology. Chapter 9, Electrical thermometers, Instr. Pract. 18,41 ( Jan.).

Rozenshtok, Yu. L., Statistical characteristics of the temperature measurement procedure for a uniform steady-state turbulent flow, Inzh. Fiz. Zh. (Feb.).

Shashkov, A.G., Block diagrams for measuring flow parameters by means of thermistors, Inzh. Fiz. Zh. 9 , 87 (Sept.).

Shu, H. H. H., E. W. Gay̆lord, and W. F. Hughes, Relation between the rubbing interface temperature distribution and dynamic thermocouple temperatures, Trans. ASME D86, 417 (Sept.).

Sklarew, S., The problem of accurately measuring changing temperatures of nonmetallic surfaces, Am. Soc. Metals 2 , 235.

Slaughter, J.I., and J.L. Margrave, Temperature measurement, AD-448 346.

Smetanina, L.I., The dynamic method of measuring high temperature, High Temperature 2,80 (Jan.).

Soviani, R., A new way of determining the thermal inertia of temperature transducers, Acta Imeko 1964, 369. Paper No.. 23-RU-226.

Stepanov, G.P., and Yu. N. Kulikov, Investigation of dynamic characteristics of temperature sensors for a retarded air flow, N64-25590.

Strutter, E., and G. Luck, On the measurement of time constants of thermocouples, Jena Rev. No. 9, 210.

Tartakovskii, D.F., Computation of the thermal inertia of commercial thermal detectors Measurement Techniques No. 11 , 922 (Apr.).

Tereshchenko, A.F., On the method of measuring surface temperature, Ind. Lab. $30,422(\mathrm{oct}$.$) .$

vanvor, $H_{.}$, Temperature measurement in the laboratory, Glas-Instr. Tech. $\underline{8}$, 171 .

Vrolyk, J.J., and P.A. Kinzie, Feasability investigation of heat-flowrote measuring techniques, Final Rept. (Jan.) RTD-TDR-63-4077; AD-431189; N65-22074.

Walker, R.F., High temperature measurements and standards $100^{\circ}$ - 30\%, High temperature technology; International union of pure and applied chemistry, Commission on high temperatures and refractories, International symposium, Pacific Grove, Calif.., Sept. 8-11, 1963, Proceedings, Butterworth and Co. (Pub(ishers), Ltd., London p. 7.

Zysk, E.D., Noble metals in thermometryrecent developments, Engel hard Inds. Tech. Bull. 5, 69 (Dec.).

Evaluation of femperature probes, AD- 442 102 .

Guide posts to keep thermocouple users out of hot water, S.A.E. J. 72, 82(Aug.)

High temperature materials program progress rept. No. 41, Part A, Nov. 30, Genera I Electric Co., Cincinnati, ohio, GEMP-41A; NSA 19-11669.
Mass flow by temperature measurement, Instr. Control Systems 37, 95 (Mar.).

\section{5}

Angerhofer, A.W., Cryogenic instrumentation, 1Sensing temperature and level, Control Eng. 12, 67 (oct.).

Atkins, R.M., Advances in thermal instrumentation, Ind. Research 7,84 (June).

Barber, J.A., Measurements of high temperatures, U.S. At. Energy Comm., Sandia Corp., A I buquerque, N.M. CONF-650204-7; SC-DC65-1237; NSA 19-30489.

Bliss, P., and S. Fanciullo, High temperature thermometry at Pratt and Whitney aircraft-canel, Pratt and Whitney Aircraft, Middle town, Conn. PWAC-462; N65-24955.

Field, R.T., Temperature sensors, N65-3i353.

Harris, H., Comparing the three most popular temperature sensors, Electron. Design 13,62 ( Jan.).

Jasicki, Z., and A. Handke, Some problems concerning temperature measurement of a hot gas stream, Pomiary, Automat. Kontrola 11 , 340 (Aug.). .

Johansson, J., Cryogenic measurements, Instr. Control Systems 38, 107 (May).

Kennedy, R.H., Sensing and measuring temperature in manufacturing environments, Automation 12,78 (Oct.).

Lieneweg, F., VDE/VDI 3511 Guide "Technical temperature measurement," Arch. Tech. Messen No. 350, 49 (Mar.).

McCoy, J.G., An improved method for the reduction of rocketsonde temperature data, Army Electronics Research and Development Activity, White Sands Missile Range, N.M. ERDA-279; AD-458 318; N65-19556.

ogale, V.A., Temperature measurements a high temperatures and high speeds- a literature survey, N65-35056.

oshima, K., Low temperature work in Japan, Cryogenics $\underline{5}, 1$ (Feb.).

Rozenshtok, Yü.L., Dynamic characteristics of a stationary l inear system for measuring temperature, Measurement Techniques No. 3, 240 (Aug.).

Rozenshtok, Yu.L., Dispersion and accidental error of measurement of temperature of locally turbulent flow, N65-30420.

Schwarzer, H., The electrical measurement of temperature and measurement systems, Arch. Tech. Messen No. 356, 197 (Sept.).

Segletes, T., A bibliography of aerothermal sensing techniques, Martin Co.., Baltimore, Md. Rept. No. ER-13687; AD-464 119.

Smith, C., Temperature sensing elements, Product Des. Eng. 3,74 (Sept.).

Yaryshev, N.A., Heat-exchange formula for thermometers which takes into account heat removal and radiation, Measurement Techniques No. 5, 411 (May).

Methods of high-temperature measurement of gases: compilation of abstracts, Aerospace Technology Div., Library of Congress Rept.ATD-P-65-53; AD-618 532 . 


